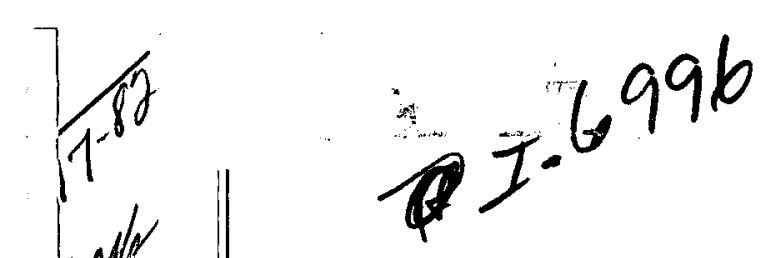

Dr. 1063

LBL-14681

GSRMP-13

UC-66e

\title{
A Comparison of Estimated and Background Subsidence Rates in Texas-Louisiana Geopressured Geothermal Areas
}

\author{
L. M. Lee, M. Clayton, J. Everingham, R. C. Harding, and A. Massa
}

EDAW-ESA, a Joint Venture of EDAW, Inc., and Earth Sciences Associates 701 Welch Road

Palo Alto, CA 94304 写ubsidente June 1982 佷esearch IUTanagement DO NOT MICROFILM
COVER

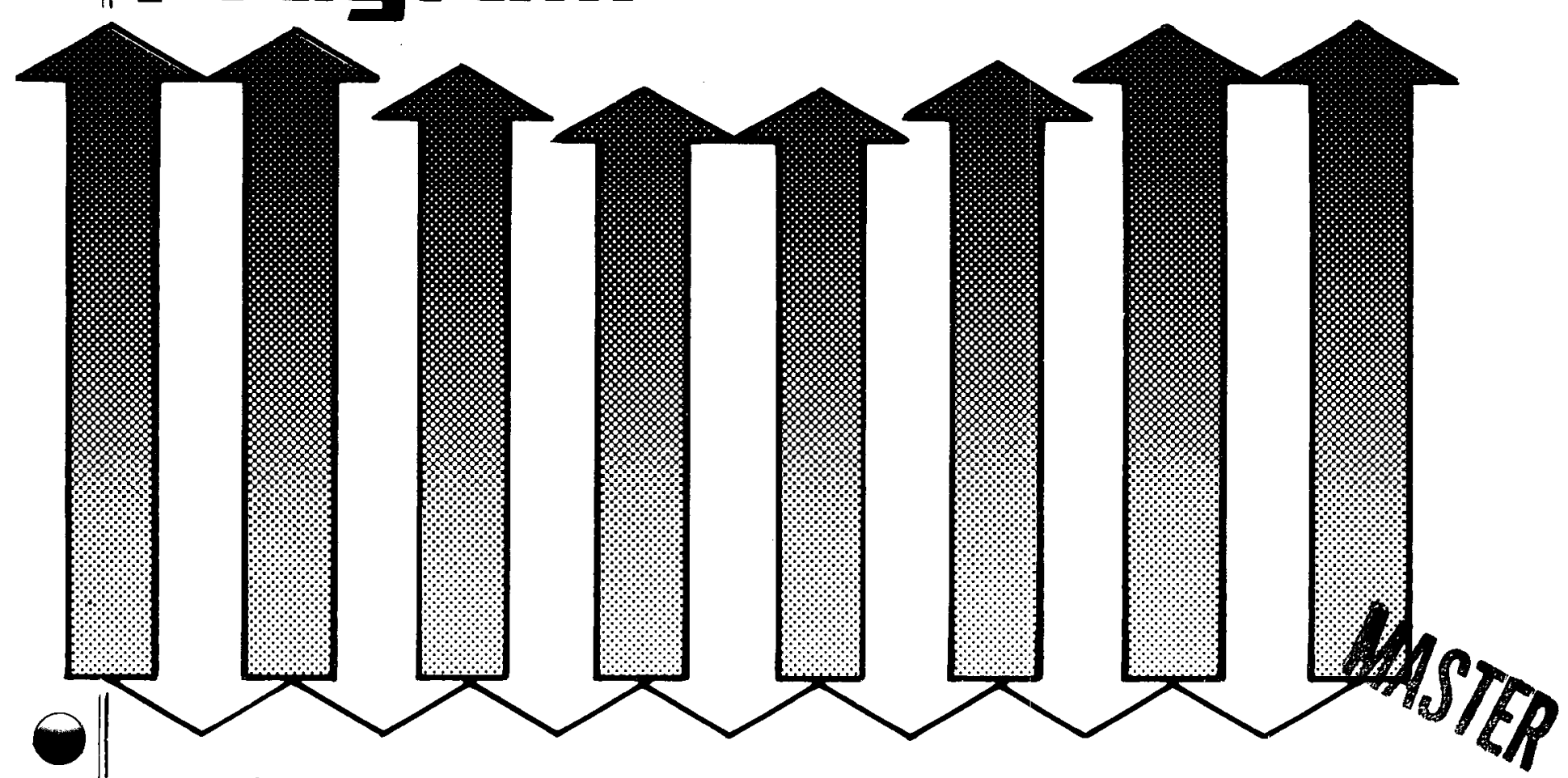

Earth Sciences Division Lawrence Berkeley Laboratory University of California, Berkeley, CA 94720

Prepared for the U.S. Department of Energy under Contract DE-AC03-76SF00098. 


\title{
DO NOT MICROFLM DO COVER $-\ldots+\cdots$
}

\section{LEGAL NOTICE}

This book was prepared as an account of work sponsored by an agency of the United States Government. Neither the United States Government nor any agency thereof, nor any of their employees, makes any warranty, express or implied, or assumes any legal liability or responsibility for the accuracy, completeness, or usefulness of any information, apparatus, product, or process disclosed, or represents that its use would not infringe privately owned rights. Reference herein to any specific commercial product, process, or service by trade name, trademark, manufacturer, or otherwise, does not necessarily constitute or imply its endorsement, recommendation, or favoring by the United States Government or any agency thereof. The views and opinions of authors expressed herein do not necessarily state or reflect those of the United States Government or any agency thereof.

\section{\&}

\author{
Printed in the United States of America \\ Available from \\ National Technical Information Service \\ U.S. Department of Commerce \\ 5285 Port Royal Road \\ Springfield, VA 22161 \\ Price Code: A07
}




\section{DISCLAIMER}

This report was prepared as an account of work sponsored by an agency of the United States Government. Neither the United States Government nor any agency Thereof, nor any of their employees, makes any warranty, express or implied, or assumes any legal liability or responsibility for the accuracy, completeness, or usefulness of any information, apparatus, product, or process disclosed, or represents that its use would not infringe privately owned rights. Reference herein to any specific commercial product, process, or service by trade name, trademark, manufacturer, or otherwise does not necessarily constitute or imply its endorsement, recommendation, or favoring by the United States Government or any agency thereof. The views and opinions of authors expressed herein do not necessarily state or reflect those of the United States Government or any agency thereof. 


\section{DISCLAIMER}

Portions of this document may be illegible in electronic image products. Images are produced from the best available original document. 
LBL --14681

LBL- 14681

GSRMP -13

DE83 004095

\section{A COMPARISON OF}

ESTIMATED AND BACKGROUND SUBSIDENCE RATES

IN TEXAS-LOUISIANA GEOPRESSURED GEOTHERMAL AREAS

\section{Prepared by}

L.M. Lee, M. Clayton, J. Everingham, R.C. Harding, and A. Massa

${ }_{950^{3}}{ }_{966^{8}}$
EDAW-ESA, a Joint Venture

of EDAW, Inc., and Earth Sciences Associates

701 Welch Road

Palo Alto, California 94304

\section{Prepared for}

Earth Sciences Division

Lawrence Berkeley Laboratory

University of California

Berkeley, California 94720

June 1982

\section{NOTICE}

PORTIONS OF THIS REPORT ARE ILLEGIBLE. It

has been reproduced from the best available

copy to permit the broadest possible avait-

ability.

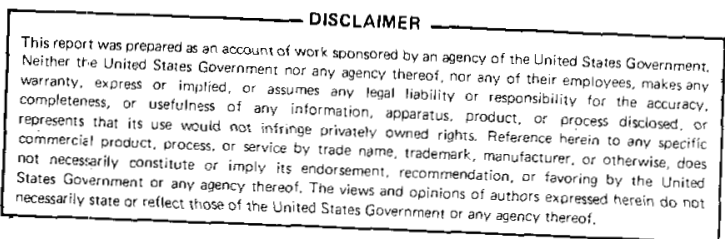

This work was supported by the Assistant Secretary for Conservation and Renewable Energy, Office of Renewable Technology, Division of Geotherma 1 and Hydropower Technologies of the U.S. Department of Energy under Contract No. DE-AC03-76SF00098 with Lawrence Berkeley Laboratory through Subcontract No. 4512110 . 
$\vartheta$

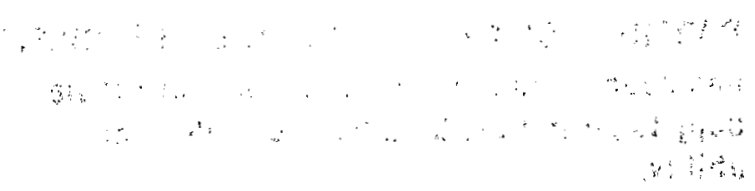


This report was prepared by EDAW-ESA under Lawrence Berkeley Laboratory Subcontract No. 4512110 during the period May 1, 1981 to May 15, 1982. EDAW-ESA is a joint venture of EDAW, Inc., an environmental planning firm, and Earth Sciences Associates (ESA), a geotechnical consulting firm. Responsibilities for various phases of this work were as follows:

Project Management: EDAW-ESA, a joint venture

Richard C. Harding, Principal-in-charge

Linda M. Lee, Project Manager

Environmental Studies: EDAW, Inc.

Alison Massa, John Everingham, Michael Clayton

Subsidence Studies: ESA, Linda M. Lee

This work was supported by the Assistant Secretary for Conservation and Renewable Energy, Office of Renewable Technology, Division of Geothermal and Hydropower Technologies of the U.S. Department of Energy under Contract No. DE-AC03-76SF00098 with Lawrence Berkeley Laboratory through Subcontract No. 4512110. The program was administered under the technical direction of Norman Goldstein. Mr. R.J. Arri was the contract administrator for Lawrence Berkeley Laboratory. 


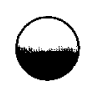

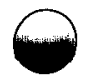




\section{TABLE OF CONTENTS}

LIST OF FIGURES vii

LIST OF TABLES $\quad$ xi

I. INTRODUCTION 1

A. Purpose 1

B. Preceding Studies 2

C. Scope 3

II. SUMMARY 5

III. GULF COAST SUBSIDENCE RATES $\quad 7$

A. Estimated Potential Geopressured-Related Rates 7

1. EDAW-ESA Estimates $\quad 8$

2. Other Estimates 12

B. Background Rates $\quad 12$

C. Comparison of Background and Potential
Geopressured-Related Rates

1. EDAW-ESA Estimates $\quad 15$

2. Other Estimates $\quad 15$

IV. ENVIRONMENTAL RESPONSE TO SUBSIDENCE

A. Subsidence-Related Ground Movements 31

B. Effects of Subsidence on Surficial Processes

C. Effects of Subsidence on Gulf Coast Ecosystems 38

1. Gulf Coast Habitats $\quad 38$

2. Subsidence and Ecosystem Dynamies 51

3. Capability of Ecosystems to Adapt to Subsidence 58 
V. GEOPRESSURED GEOTHERMAL-RELATED SUBSIDENCE: POTENTIAL IMPACTS AND SIGNIFICANCE

A. Cuero Prospect $\quad 65$

B. Pleasant Bayou Prospect $\quad 68$

C. Gladys McCall Prospect $\quad 70$

$\begin{array}{ll}\text { D. Southeast Pecan Island Prospect } & 73\end{array}$

VI. REFERENCES CITED

APPENDIX: Background Subsidence Rates $\quad$ A-i 
I-1 Location Map

III-1 Background Subsidence Rates Compared to Potential Geopressured Geothermal-Related Subsidence Rates First Year of Production - Cuero Prospect, Texas

III-2 Background Subsidence Rates Compared to Potential Geopressured Geothermal-Related Subsidence Rates Twentieth Year of Production - Cuero Prospect, Texas

III-3 Total Background Subsidence Compared to Total Potential Geopressured Geothermal-Related Subsidence - Over 20-Year Production Life - Cuero Prospect, Texas

III-4 Background Subsidence Rates Compared to Potential Geopressured Geothermal-Related Subsidence Rates First Year of Production - Pleasant Bayou Prospect, Texas

III-5 Background Subsidence Rates Compared to Potential Geopressured Geothermal-Related Subsidence Rates Year 5.5 of Production Life - Pleasant Bayou Prospect, Texas

III-6 Total Background Subsidence Compared to Total Potential Geopressured Geothermal-Related Subsidence - Over 5.5-Year Production Life - Pleasant Bayou, Texas

III-7 Background Subsidence Rates Compared to Potential Geopressured Geothermal-Related Subsidence Rates First Year of Production - Gladys McCall Prospect, Louisiana

III-8 Background Subsidence Rates Compared to Potential Geopressured Geothermal-Related Subsidence Rates Twentieth Year of Production - Gladys McCall Prospect, Louisiana

III-9 Total Background Subsidence Compared to Total Potential Geopressured Geothermal-Related Subsidence 
III-10 Background Subsidence Rates Compared to Potential Geopressured Geothermal-Related Subsidence Rates First Year of Production - Southeast Pecan Island Prospect, Louisiana

III-11 Background Subsidence Rates Compared to Potential Geopressured Geothermal-Related Subsidence Rates Twentieth Year of Production - Southeast Pecan Island Prospect, Louisiana

III-12 Total Background Subsidence Compared to Total Potential Geopressured Geothermal-Related Subsidence - Over 20-Year Production Life - Southeast Pecan Island Prospect, Louisiana

III-13 Total Background Subsidence Compared to Total Potential Geopressured Geothermal-Related Subsidence - Over 9-Month Test Period - Parcperdue Prospect, Louisiana

III-14A Background Subsidence Rates Compared to Geopressured Geothermal-Related Subsidence Rates First and Fifth Years of Test Period - Armstrong Prospect, Texas

III-14B Total Background Subsidence Compared to Total Geopressured Geothermal-Related Subsidence - Over 5Year Test Period - Armstrong Prospect, Texas

IV-1 Flowchart Depicting the Potential for Adverse Impacts Due to the Linkages between Subsidence Phenomena, Surficial Processes, and Ecological Systems

IV-2 Plan View and Profile of Typical Subsidence Bowl

IV-3 The Effects of Abandonment of a Deltaic Distributary System

IV-4 The Effect of Subsidence in Shallow Groundwater Areas

IV-5 Diagrammatic Habitat Cross Section

IV-6 Conceptual Habitat Linkage for the Gulf Coastal Ecosystem

IV-7 Systems Diagram of a Gulf Coastal Brackish Marsh 


\section{LIST OF FIGURES (Continued)}

$\begin{array}{ll}\text { V-1 } & \text { Cuero Prospect Habitat Map } \\ \text { V-2 } & \text { Pleasant Bayou Prospect Habitat Map } \\ \text { V-3 } & \text { Gladys MeCall Prospect Habitat Map } \\ \text { V-4 } & \text { Southeast Pecan Island Prospect Habitat Map } \\ \text { V-5 } & \begin{array}{l}\text { Two Cause-and-Effect Pathways for Subsidence } \\ \text { of Brackish Marsh Habitat in the Southeast } \\ \text { Pecan Island Study Area }\end{array}\end{array}$

66 


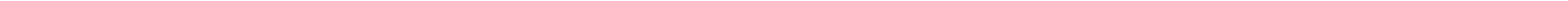




\section{LIST OF TABLES}

III-1 Background and Potential Geopressured GeothermalRelated Subsidence Rates

III-2 Summary of Development Scenarios $\quad 10$

III-3 Ratio of Combined Background and Potential Geopressured Geothermal-Related Subsidence Rates to Background Subsidence Rates

IV-1 Energy/Mass Flow Symbols and Their Definitions

IV-2 Partial Listing of References for Coastal Ecosystem Energy/Mass Flow Diagrams 
$\ominus$

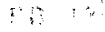

$\therefore \therefore$

$\ominus$ 


\section{INTRODUCTION}

\section{A. Purpose}

The existing natural environment of the Texas-Louisiana Gulf Coast is not static. Subsidence, or a lowering of the ground surface, is presently occurring as a result of several natural and man-induced processes. ${ }^{1}$ Any subsidence caused by geopressured geothermal resource development would be superimposed on these background processes.

The capacity of prospective geopressured geothermal development areas to absorb small additional rates of subsidence (such as estimated by EDAW-ESA, 1980) without producing adverse environmental impacts has not previously been studied. Of concern, for example, is whether subsidence of one centimeter per year extending over a subsidence bowl several tens of square kilometers in size would be sufficiently small to be indistinguishable from the present background subsidence now occurring in the Gulf Coast area? Reliable evaluation of environmental impacts of potential geopressured geothermal subsidence requires comparison of predicted subsidence rates to background subsidence rates.

Accordingly, the objectives of this report are to:

1. Establish for the Texas-Louisiana Gulf Coast the rates of subsidence caused by on-going natural and man-induced processes.

2. Compare these background rates of subsidence with estimated subsidence rates associated with potential geopressured geothermal resource development.

3. Evaluate the significance of potential geopressured geothermal-related subsidence rates in light of ongoing background subsidence rates.

1

In this report, presently occurring natural and man-induced subsidence are together called "background" subsidence, to distinguish them from any potential future subsidence caused by geopressured geothermal resource development. 


\section{B. Preceding Studies}

In 1977-78, ESA joined with Systems Control, Inc. in a project for Lawrence Berkeley Laboratory (LBL) to prepare subsidence case histories for four geothermal areas. One of these was the Chocolate Bayou oil and gas field near Houston, Texas, less than 15 kilometers from the Department of Energy (DOE)-General Crude Pleasant Bayou Design Well. This study involved a detailed evaluation of all conditions that could affect subsidence, including seismicity, geology and structure of reservoir and overburden materials, material properties, fluid production from shallow and deep zones, geohydrology, and pressure declines in the reservoir. Because of DOE and LBL interest in Chocolate Bayou, ESA also performed a data availability assessment of that field to determine whether sufficient data were available (and accessible) to support a realistic modeling effort.

In 1978-79, EDAW-ESA studied the environmental and economic effects of subsidence in nine areas around the world, including the Houston region, for which adequate data were available. This LBL-directed research continued in 1979-80 with the preparation of a subsidence research plan to pinpoint future research needs. As part of this project, EDAW-ESA, in conjunction with Gruy Federal (petroleum engineering consultants based in Houston), developed site-specific development scenarios and state-of-the-art subsidence estimates for four geopressured geothermal prospects.

In the process of performing the above work, the EDAW-ESA project team found that subsidence impact is sometimes discussed as if maximum subsidence occurs instantaneously. However, because subsidence occurs as a gradual, continuous function of time, depending on production, the rate of subsidence may be the key parameter in evaluating whether natural and man-made systems can adjust to subsidence. Therefore, the present study was undertaken to determine the significance of potential geopressured geothermal resource development-related subsidence rates in light of the ongoing subsidence rates induced by natural and man-induced processes. 


\section{Scope}

The comparison of background and potential geopressured geothermal development-related subsidence rates is given in Chapter III. Estimated potential geopressured-related rates at the Cuero, Pleasant Bayou, Gladys McCall, and Southeast Pecan Island prospects studied by EDAW-ESA (1980), as well as for two other prospects (Parcperdue and Armstrong), are presented (Figure I-1). Background rates for each of these sites are determined from material presented in the Appendix. As a summation for Chapter III, Table III-3 presents ratios for each site showing how many times greater than background rates alone would be potential and background rates together.

In Chapter IV, we examine the effect of subsidence on the Texas-Louisiana Gulf Coast. First, the various ground movements associated with subsidence (vertical surface movement, tilting, subsurface deformation, fissuring, and horizontal movement) are described. Next, possible effects of these ground movements on surficial processes (such as stream flow, sedimentation, lake formation, erosion, and tidal flow) are discussed. Finally, in the third section of Chapter IV, the relationships between ecosystems and subsidence, including the capabilty of geologic and biologic systems to adapt to subsidence, are analysed.

In light of the information presented in the previous chapters, Chapter $V$ addresses the actual potential for environmental impact caused by potential geopressured-related subsidence at each of the four prospects studied by EDAW-ESA (1980). A summary of these results is given in Chapter II. 


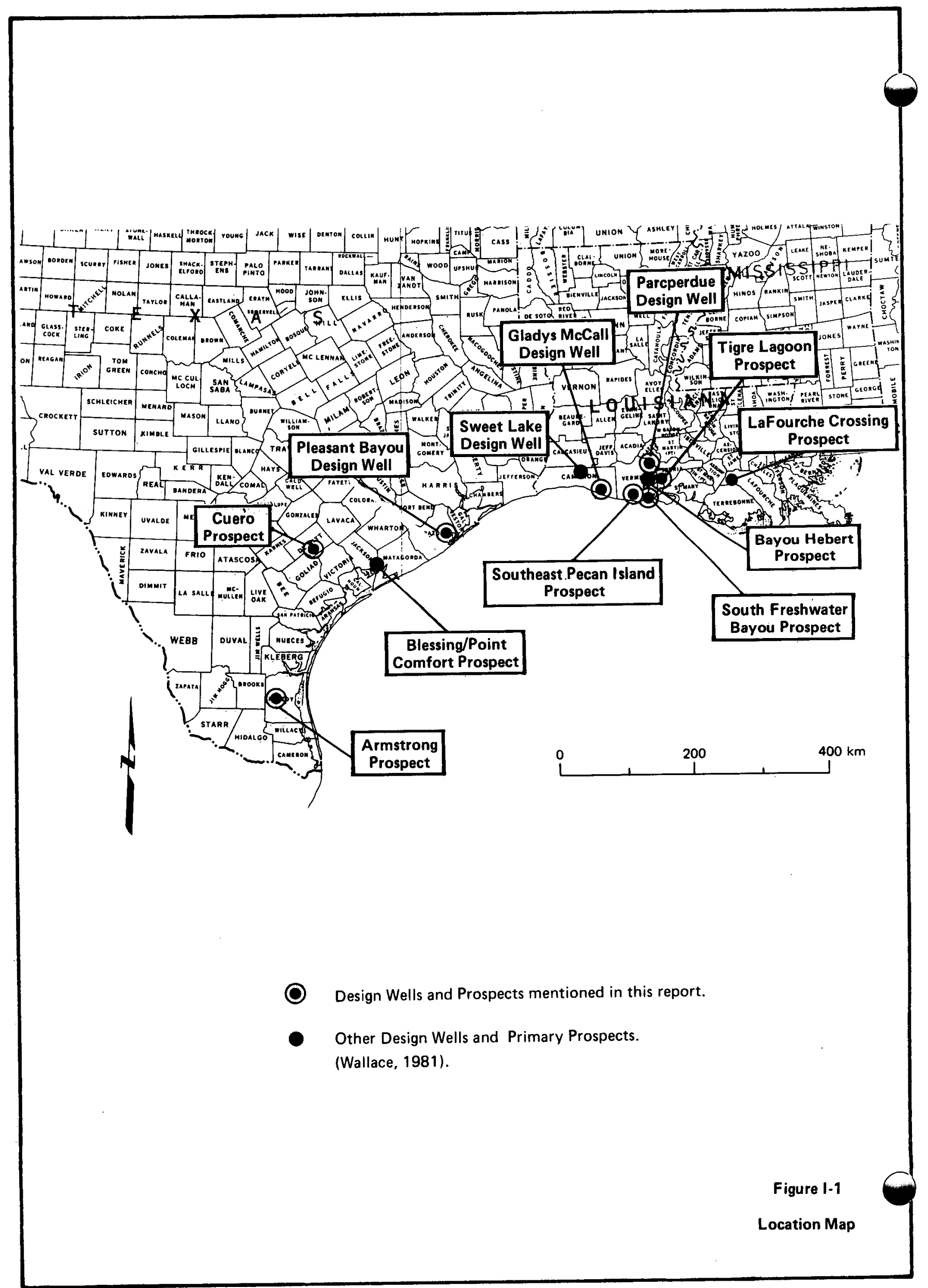




\section{SUMMARY}

The Texas-Louisiana Gulf Coast is currently experiencing varying rates of both man-induced and natural land subsidence. As a result, the Gulf Coast is a dynamic environment undergoing continuous changes in geomorphology and habitat. These changes are particularly evident in the near-sea-level coastal marshlands, where the fauna and flora are in a state of constant change as they adapt or fail to adapt to natural change. The presently occurring natural and man-induced rates of subsidence have been combined, for the purposes of this study, in order to provide a rate comparison between current (background) subsidence and estimated geopressured geothermal-related subsidence. The potential geopressured-related subsidence impacts discussed in the following paragraphs have been determined by evaluating the potential incremental change or acceleration of impacts over those caused by background subsidence.

\section{Cuero Prospect}

For the Cuero Prospect area, substantial alterations to the local hydrologic regime are not likely to occur. Therefore, no significant vegetation or wildlife impacts are anticipated from geopressured geothermal-related subsidence.

\section{$\underline{\text { Pleasant Bayou Prospect }}$}

For the Pleasant Bayou Prospect area, the combination of low rates and magnitude of projected geopressured geothermal-related subsidence with the upland nature of the affected habitats indicates that geopressured geothermal resource development is not expected to induce significant subsidence impacts. It is anticipated that this site would be the least impacted of the four prospects.

\section{- Gladys McCall Prospect}

The geopressured geothermal subsidence projected for the Gladys McCall Prospect area would significantly compound the impacts attributable to background subsidence, resulting in increased tidal inundation and loss of habitat, primarily involving brackish/intermediate marsh. However, it is anticipated that the Grand 
Chenier Ridge system (Highway 82) would tend to confine the impact area to the region south of the Ridge.

Southeast Pecan Island Prospect

For the Southeast Pecan Island Prospect area, impacts attributable to the incremental difference between background and geopressured geothermal-related subsidence would be significant owing to the magnitude of the projected geopressured geothermal-related subsidence and the characteristic vulnerability of the wetland habitats. Localized ecosystem disruption, and recreation and economic resource loss would produce the most significant geopressured geothermal-related subsidence impact of the four study areas. 


\section{GULF COAST SUBSIDENCE RATES}

\section{A. Estimated Potential Geopressured-Related Rates}

In 1980, EDAW-ESA, under the direction of the Lawrence Berkeley Laboratory and the Department of Energy (DOE), estimated potential subsidence which might stem from resource development of four Gulf Coast geothermal geopressured prospects. The prospects studied were Cuero (Texas), Pleasant Bayou (Texas), Gladys McCall (Louisiana), and Southeast Pecan Island (Louisiana) (Figure I-1). Of these, Pleasant Bayou and Gladys McCall have been drilled as DOE Design Wells. The Southeast Pecan Island site is itself no longer being considered for a DOE Design Well, but its location is less than ten miles west of a new prospect - South Freshwater Bayou - now under study as a site for a Design Well. The Cuero prospect is no longer being seriously considered for Design Well status.

Estimates of potential subsidence caused by geopressured geothermal resource development in the Gulf Coast area have also been made by other investigators (Coastal Environments, 1976; Kreitler and Gustavson, 1976; White and others, 1978; Gustavson and others, 1980; Janssen and Carver, 1981). The prospects studied include Tigre Lagoon (Louisiana), Armstrong (Texas), Pleasant Bayou (same as in the EDAW-ESA study), and Parcperdue (Louisiana). Of these, Pleasant Bayou and Parcperdue have already been drilled as DOE Design Wells. Armstrong and Tigre Lagoon are not now being considered for Design Wells.

The potential subsidence estimates made by Coastal Environments (1976), Kreitler and Gustavson (1976), and Gustavson and others (1980) for the Tigre Lagoon, Armstrong, and Pleasant Bayou prospects, respectively, are not included in our present study for the following reasons:

Tigre Lagoon - Subsidence was calculated for a short test period of only 20 days. For that short a time period, Coastal Environments (1976, p. 71) indicated that shale dewatering would not have any effect on subsidence. Their potential subsidence estimate was, therefore, based only on sandstone compaction. Also, the methods used to calculate subsidence at Tigre Lagoon were not presented, so other development assumptions used for this site are 
not known. It is not appropriate to extrapolate subsidence estimated for only 20 days into an annual subsidence rate, particularly without knowing details of the method and assumptions used.

Armstrong - Gustavson (personal commun., 1982) indicates that the total subsidence estimated in his report should not be transformed into subsidence rates.

Pleasant Bayou - The data and calculations presented (Gustavson and others, 1980) are for a somewhat hypothetical reservoir and are inconsistent within themselves, so that projected subsidence values and calculated subsidence rates are of questionable value.

\section{EDAW-ESA Estimates}

The EDAW-ESA subsidence estimates (see Table III-1) were based on certain assumptions, known cumulatively as "development scenarios", used to model reservoir development (EDAW-ESA, 1980, p. 8). Some of the assumptions common to all four sites are:

- Each site is developed with one well.

- No reinjection takes place at any depth.

- There is no surface distortion caused by movement of growth faults.

The development scenarios particular to each of the four subsidence analysis prospects are summarized in Table III-2.

Using the development scenarios, potential compaction in each geopressured reservoir was calculated using the following equations:

$$
\mathrm{C}_{\text {sandstone }}=\mathrm{H}_{\mathrm{ss}} \mathrm{C}_{\mathrm{m}} \Delta \mathrm{p}
$$

and

$$
\mathrm{C}_{\text {shale }} \quad=\mathrm{H}_{\mathrm{sh}} \mathrm{C}_{\mathrm{m}} \Delta \mathrm{pU} \%
$$


Table III-1

\section{Background and Potential Geopressured Geothermal-Related Subsidence Rates}

\begin{tabular}{|c|c|c|c|c|c|c|c|}
\hline \multirow[b]{3}{*}{$\begin{array}{l}\text { Geopressured Geothermal } \\
\text { Design Well or Prospect }\end{array}$} & \multirow{3}{*}{$\begin{array}{l}\text { Production } \\
\text { or Test } \\
\text { Life (yrs) }\end{array}$} & \multicolumn{2}{|c|}{ Background Subsidence } & \multicolumn{4}{|c|}{ Potential Geopressured-Related Subsidence } \\
\hline & & \multirow[b]{2}{*}{$\begin{array}{l}\text { Rate } \\
(\mathrm{mm} / \mathrm{yr})\end{array}$} & \multirow{2}{*}{$\begin{array}{l}\text { Total Over } \\
\text { Production } \\
\text { or Test } \\
\text { Life }(\mathrm{mm})\end{array}$} & \multicolumn{3}{|c|}{ Rate $(\mathrm{mm} / \mathrm{yr})$} & \multirow{2}{*}{$\begin{array}{l}\text { Total Over } \\
\text { Production } \\
\text { or Test Life } \\
(\mathrm{mm})\end{array}$} \\
\hline & & & & $\begin{array}{l}\text { First } \\
\text { Year }\end{array}$ & $\begin{array}{l}\text { Middle } \\
\text { Year }\end{array}$ & $\begin{array}{l}\text { Last } \\
\text { Year }\end{array}$ & \\
\hline \multicolumn{8}{|l|}{ EDAW-ESA (1980, Appendix G) } \\
\hline Cuero, TX & 20 & 2 & 40 & 16 & 3 & 0.3 & 85 \\
\hline Pleasant Bayou, TX & 5.5 & 6 & 30 & 7 & 3 & 0.5 & 16 \\
\hline Gladys McCall, LA & 20 & 5 & 100 & 7.7 & 7 & 5 & $100+$ \\
\hline Southeast Pecan Island, LA & 20 & 6 & $100+$ & 14 & 12 & 8 & $200+$ \\
\hline \multicolumn{8}{|l|}{ Other Studies } \\
\hline $\begin{array}{l}\text { Parcperdue, LA (Janssen } \\
\text { and Carver, 1981) }\end{array}$ & 0.75 & 3 & 2 & 2 & - & - & $1+$ \\
\hline $\begin{array}{l}\text { Pleasant Bayou, TX } \\
\text { (White and others, 1978) }\end{array}$ & 5 & 6 & 30 & 60 & - & 9.3 & 147 \\
\hline $\begin{array}{l}\text { Armstrong, TX } \\
\text { (White and others, 1978) }\end{array}$ & 5 & 2 & 10 & 55 & - & 8.7 & 137 \\
\hline
\end{tabular}


Table III-2

\section{Summary of Development Scenarios}

\begin{tabular}{|c|c|c|c|c|c|c|c|}
\hline $\begin{array}{l}\text { Geopressured Geothermal } \\
\text { Design Well or Prospect }\end{array}$ & 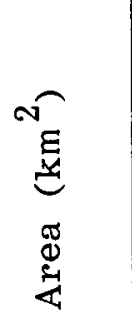 & 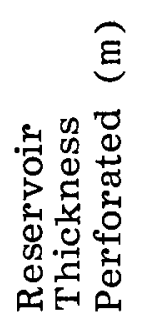 & 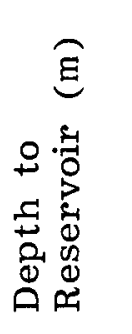 & 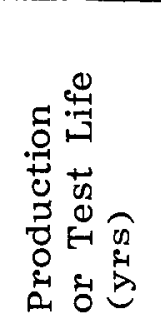 & 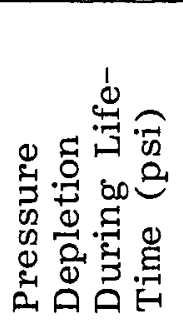 & 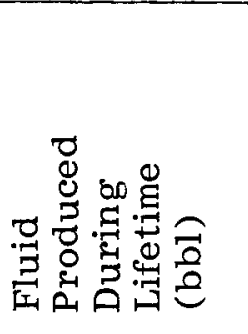 & 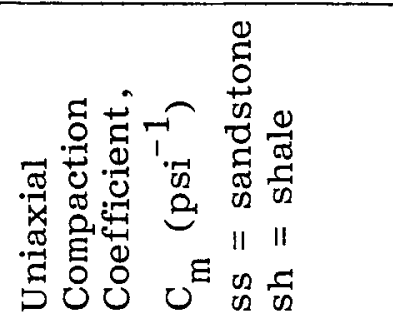 \\
\hline \multicolumn{8}{|l|}{ EDAW-ESA $(1980$, p. 8,65$)$} \\
\hline Cuero, TX & 28 & 60 & 3,850 & 20 & 3,766 & $40,930,000$ & $\begin{array}{l}\text { ss } 6 \times 10^{-7} \\
\text { sh } 3 \times 10^{-6}\end{array}$ \\
\hline Pleasant Bayou, TX & 47 & 18 & 4,510 & 5.5 & 2,768 & $16,921,000$ & $\begin{array}{l}\text { ss } 6 \times 10^{-7} \\
\text { sh } 3 \times 10^{-6}\end{array}$ \\
\hline Gladys McCall, LA & 41 & 150 & 4,570 & 20 & 4,581 & $251,174,000$ & $\begin{array}{l}\text { ss } 6 \times 10^{-7} \\
\text { sh } 3 \times 10^{-6}\end{array}$ \\
\hline Southwest Pecan Island, LA & 52 & 150 & 4,265 & 20 & 3,610 & $247,422,000$ & $\begin{array}{l}\text { ss } 6 \times 10^{-7} \\
\text { sh } 3 \times 10^{-6}\end{array}$ \\
\hline \multicolumn{8}{|l|}{ Other Studies } \\
\hline $\begin{array}{l}\text { Parcperdue, LA (Janssen } \\
\text { and Carver, 1981) }\end{array}$ & 3.8 & 15 & 4,080 & $\begin{array}{c}0.75 \\
(9 \text { mos })\end{array}$ & 3,000 & $?$ & ss \& sh $4 \times 10^{-7}$ \\
\hline $\begin{array}{l}\text { Pleasant Bayou, TX } \\
\text { (White and others, 1978) }\end{array}$ & 41 & 255 & 4,665 & 5 & 340 & $?$ & $\operatorname{ss} 6.6 \times 10^{-6}$ \\
\hline $\begin{array}{l}\text { Armstrong, TX } \\
\text { (White and others, 1978) }\end{array}$ & 41 & 150 & 3,655 & 5 & 340 & $?$ & $\operatorname{ss} 6.6 \times 10^{-6}$ \\
\hline
\end{tabular}


where,

$$
\begin{array}{ll}
\mathrm{C}_{\text {sandstone }} & =\text { compaction of sandstone }(\mathrm{ft}) \\
\mathrm{C}_{\text {shale }} & =\text { compaction of shale }(\mathrm{ft}) \\
\mathrm{H}_{\mathrm{ss}} & =\text { thickness of perforated sandstone }(\mathrm{ft}) \\
\mathrm{H}_{\text {sh }} & =\begin{array}{l}
\text { thickness of shale within and directly } \\
\text { surrounding perforated sandstone }(\mathrm{ft})
\end{array} \\
\mathrm{C}_{\mathrm{m}} & =\text { uniaxial compaction coefficient }\left(\mathrm{psi}^{-1}\right) \\
\Delta \mathrm{p} & =\text { pressure drop vertically averaged }(\mathrm{psi}) \\
\mathrm{U} \% & =\text { degree of consolidation }
\end{array}
$$

The $\mathrm{C}_{\mathrm{m}}$ values used (see Table III-2) were the most probable based on laboratory data available at the time of the study. The rate of shale dewatering was taken into account by the U\% term. Compaction was transmitted to the land surface as subsidence using Geertsma's nucleus-of-strain method (Geertsma, 1973).

Potential subsidence was calculated over the modeled production period of each reservoir, 20 years for the Cuero, Gladys McCall, and Southeast Pecan Island sites and 5.5 years for the Pleasant Bayou site. Based on the modeled annual pressure drops, it was found that potential subsidence rates decreased non-linearly over the production life of each well because of the effect of shale dewatering. To show this non-linearity, Table III-1 presents potential subsidence rates for the first, middle, and last years of production.

At the centers of potential subsidence bowls analyzed by EDAW-ESA, subsidence rates ranged from 7 to 16 millimeters per year $(\mathrm{mm} / \mathrm{yr})$ for the first year of production and from 0.3 to $8 \mathrm{~mm} / \mathrm{yr}$ for the last year of production. The Southeast Pecan Island prospect in Louisiana has the greatest potential subsidence rate, whereas the lowest rate was estimated for Pleasant Bayou. Correspondingly, the largest total amount of subsidence estimated was more than $200 \mathrm{~mm}$, or about 9 inches, over 20 years of production at Southeast Pecan Island and the smallest total amount estimated over production life ( 5.5 years) was $16 \mathrm{~mm}$, or about onehalf inch, at Pleasant Bayou. 


\section{Other Estimates}

The subsidence calculations made in the other studies (see Table III-1) were not based on the same assumptions used to formulate the EDAW-ESA estimates. In the Parcperdue study (Janssen and Carver, 1981), subsidence was calculated over a shorter period ( 9 months) than was used by EDAW-ESA (20 or 5.5 years). Rates were based on a lumped sandstone/shale compaction coefficient which was an order of magnitude less than the coefficient EDAW-ESA (1980) used for sandstone alone. This means that the Parcperdue reservoir was modeled as firmer and more cemented than the reservoirs studied by EDAW-ESA (1980). Based on these and other development assumptions (Table III-2), an extrapolated annual rate for the Parcperdue site is relatively low: only $2 \mathrm{~mm} / \mathrm{yr}$.

White and others (1978), in their early study of the Pleasant Bayou and Armstrong sites, estimated subsidence based on compaction of sandstone only. However, for the test periods they considered ( 5 years), shale dewatering may also be an important factor in potential reservoir compaction. The thickness of reservoir used in the Pleasant Bayou calculations by White and others (1978) was fourteen times greater than the thickness used by EDAW-ESA. This greater thickness, along with a higher compaction coefficient, leads to higher rates $(60 \mathrm{~mm}$ the first year decreasing to $9 \mathrm{~mm}$ the last year) than estimated by EDAW-ESA ( 7 $\mathrm{mm}$ the first year decreasing to $0.5 \mathrm{~mm}$ the last year) for Pleasant Bayou.

\section{B. Background Rates}

Subsidence is presently occurring in the Texas-Louisiana Gulf Coast as a result of several natural and man-induced processes. As explained in the Introduction, both natural and man-induced subsidence are together referred to as "background subsidence" in this report to distinguish them from any potential future subsidence caused by geopressured geothermal resource development. Appendix contains a discussion of background subsidence rates in the TexasLouisiana Gulf Coastal Plain.

Background subsidence rates for the four sites examined in EDAW-ESA's 1980 report are shown in Table III-1. Also shown are background rates for the three sites for which potential geopressured-related subsidence has been estimated by 
other investigators. Background rates at the Pleasant Bayou and Parcperdue sites were derived from recent leveling surveys at these sites (Gustavson, 1979; Van Sickle and Groat, 1981). Background rates for the other sites were estimated from non-site-specific subsidence analyses (see the Appendix). Estimates of total background subsidence over the hypothetical production or test life of a well at each site are also given in Table III-1.

Background subsidence rates for the three Louisiana prospects are about 5-6 $\mathrm{mm} / \mathrm{yr}$, except for Parcperdue. Rates at Parcperdue are lower, about $3 \mathrm{~mm} / \mathrm{yr}$, possibly because this site is not located on the rapidly consolidating Holocene deposits, but rather on the older Quaternary sediments, which are more consolidated.

Both the Cuero and Armstrong prospects in Texas have background rates of around $2 \mathrm{~mm} / \mathrm{yr}$. These rates are low, mainly because the prospects are not in rapidly consolidating Holocene deposits nor in areas greatly affected by maninduced subsidence processes. In contrast, Pleasant Bayou is located near Houston where background subsidence rates are higher (around $6 \mathrm{~mm} / \mathrm{yr}$ ) owing to groundwater and petroleum extraction.

\section{Comparison of Background and Potential Geopressured-Related Rates}

Background and potential geopressured-related subsidence rates are compared in Figures III-1 through III-14, in which subsidence rates have been superimposed on topographic maps of the prospects under study. Maps comparing rates for the first and last years of modeled production or testing (where data were available) and maps comparing total subsidence have been prepared for each site.

A summary of the comparisons is given in Table III-3. The ratios shown indicate the relative increase in subsidence rates resulting from the addition of potential geopressured geothermal-related subsidence to background subsidence. 
Table III-3

Ratio of Combined Background and Potential Geopressured Geothermal-Related Subsidence Rates

To Background Subsidence Rates

\begin{tabular}{|c|c|c|c|c|}
\hline \multirow{2}{*}{$\begin{array}{l}\text { Geopressured Geothermal } \\
\text { Design Well or Prospect }\end{array}$} & \multirow{2}{*}{$\begin{array}{l}\text { (Total Background }+ \\
\text { Total Potential) } \\
\div \text { Total Background }\end{array}$} & \multicolumn{3}{|c|}{$\begin{array}{c}\text { (Background Rate + Potential Rate) } \\
\div \text { Background Rate }\end{array}$} \\
\hline & & First Year & Middle Year & Last Year \\
\hline EDAW-ESA (1980) & & & & \\
\hline Cuero, TX & 3 & 9 & 3 & 1 \\
\hline Pleasant Bayou, TX & 2 & 2 & 2 & 1 \\
\hline Gladys McCall, LA & 2 & 3 & 2 & 2 \\
\hline Southeast Pecan Island, LA & 3 & 3 & 3 & 2 \\
\hline Other Studies & & & & \\
\hline $\begin{array}{l}\text { Parcperdue, LA } \\
\text { (Janssen and Carver, 1981) }\end{array}$ & 1 & 2 & - & - \\
\hline $\begin{array}{l}\text { Pleasant Bayou, TX } \\
\text { (White and others, 1978) }\end{array}$ & 6 & 10 & - & 3 \\
\hline $\begin{array}{l}\text { Armstrong, TX } \\
\text { (White and others, 1978) }\end{array}$ & 10 & 30 & - & 5 \\
\hline
\end{tabular}




\section{EDAW-ESA Estimates}

As indicated in Table III-3, combined rates range from 1 to 9 times greater than background subsidence rates alone. The highest ratio is for the inland Cuero site and is only valid for the first year, the ratio dropping to 1 for the last year. All other ratios are 3 or less for any year of production.

Combined total subsidence ranges from 2 to 3 times background subsidence alone. The highest ratio for total subsidence was for the Texas site of Cuero, owing to the fact that the background subsidence is very low $(2 \mathrm{~mm} / \mathrm{yr})$ in this area. The other Texas site, Pleasant Bayou, has the lowest ratio because background subsidence is high $(6 \mathrm{~mm} / \mathrm{yr})$ due to withdrawal of water and oil and gas. Projected total subsidence at the Louisiana sites could be 2-3 times greater than background subsidence alone, based on EDAW-ESA estimates at these sites.

\section{Other Estimates}

Comparison of background and potential geopressured-related subsidence was also made for prospects analyzed by other investigators (see Table III-3). Because the ratios for these studies cannot be compared directly with those for the EDAW-ESA studies (owing to differences in development scenarios and in methods of subsidence calculation), only the EDAW-ESA ratios are referred to in this report. Nevertheless, a few comments can be made about the ratios based on the other studies:

o The ratio for Parcperdue might be higher if shale dewatering had been taken in to account in the subsidence calculation.

- The ratio for the Pleasant Bayou prospect might be lower if the same compaction coefficient and reservoir thickness used by EDAW-ESA had been employed in the study by White and others (1978). 


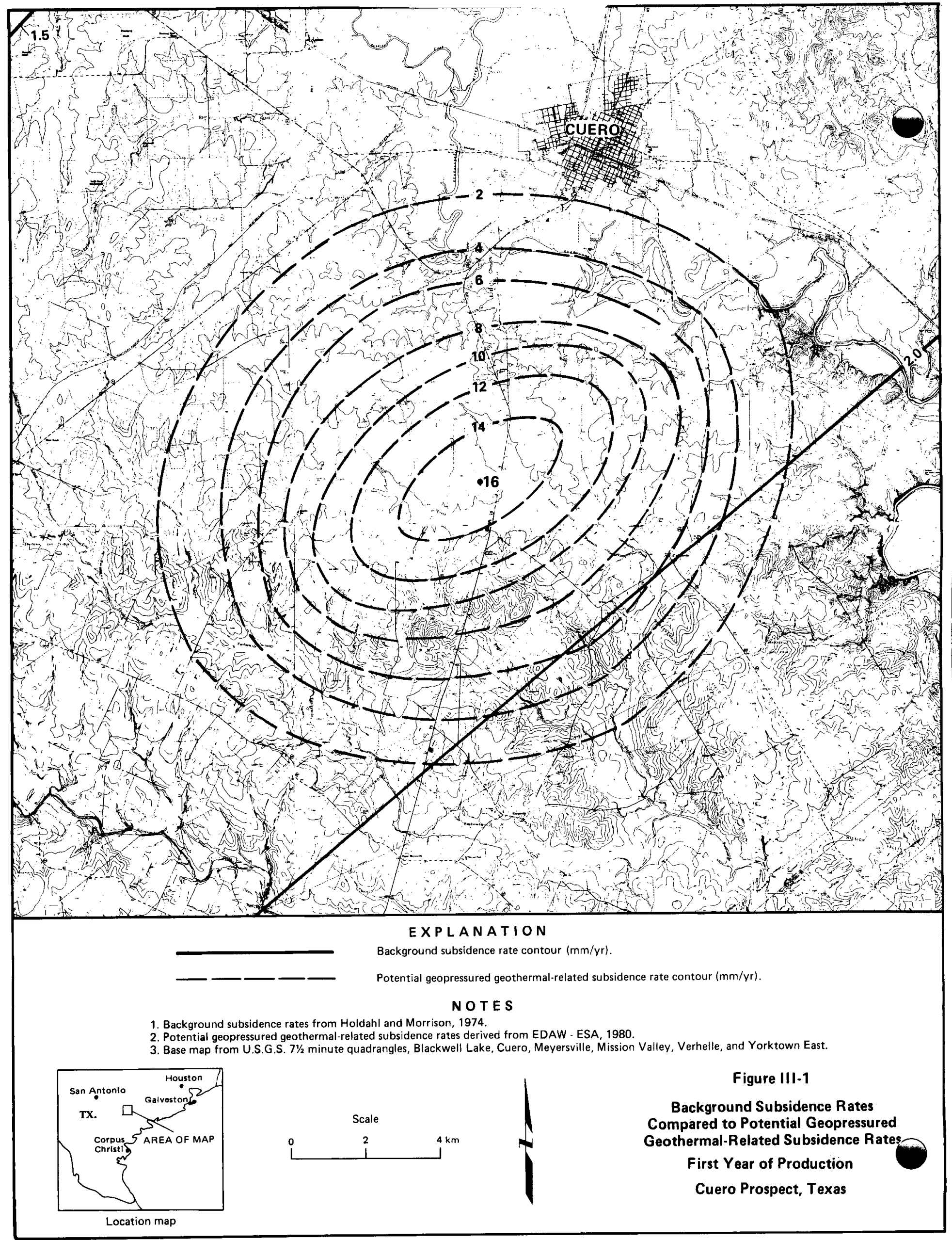




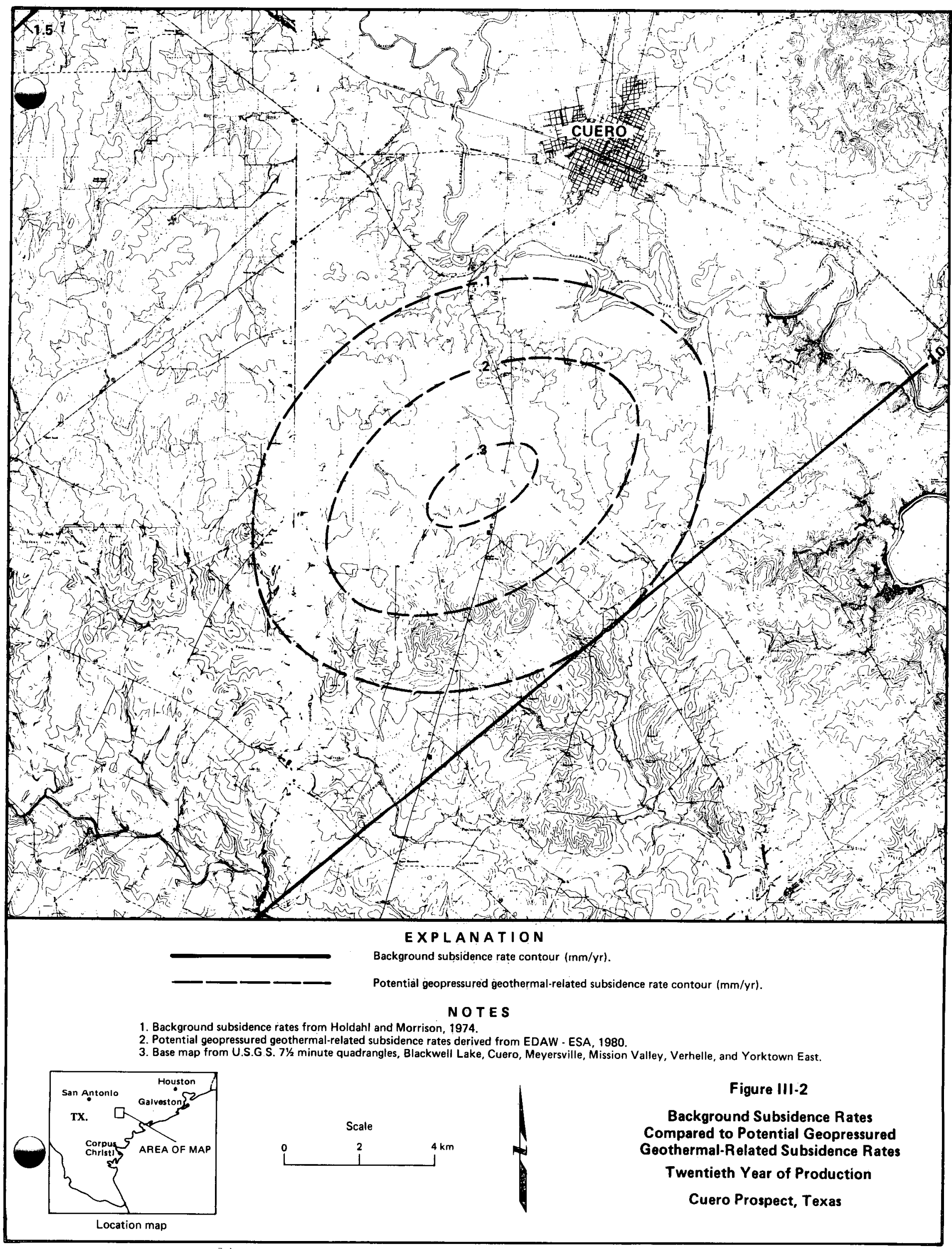




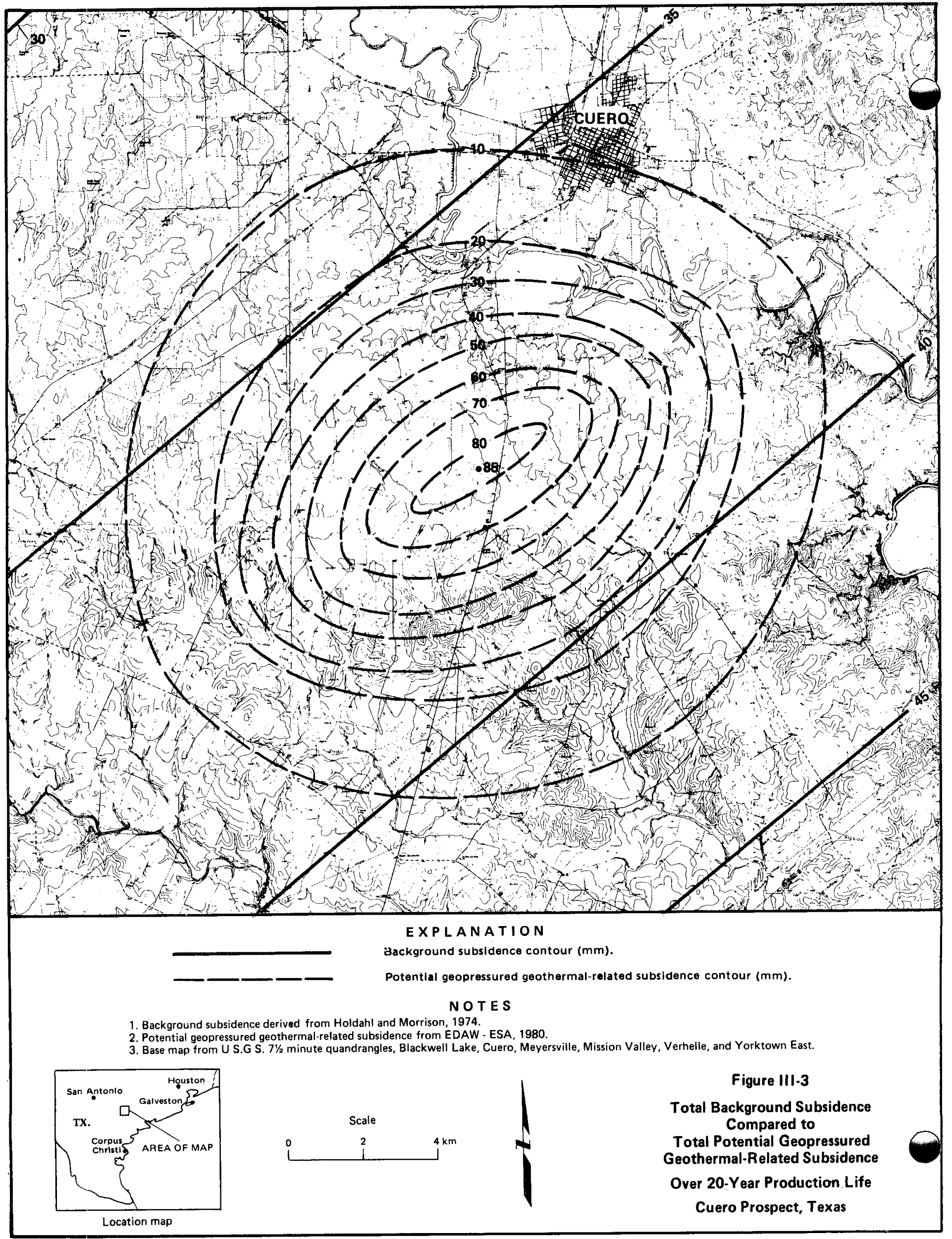




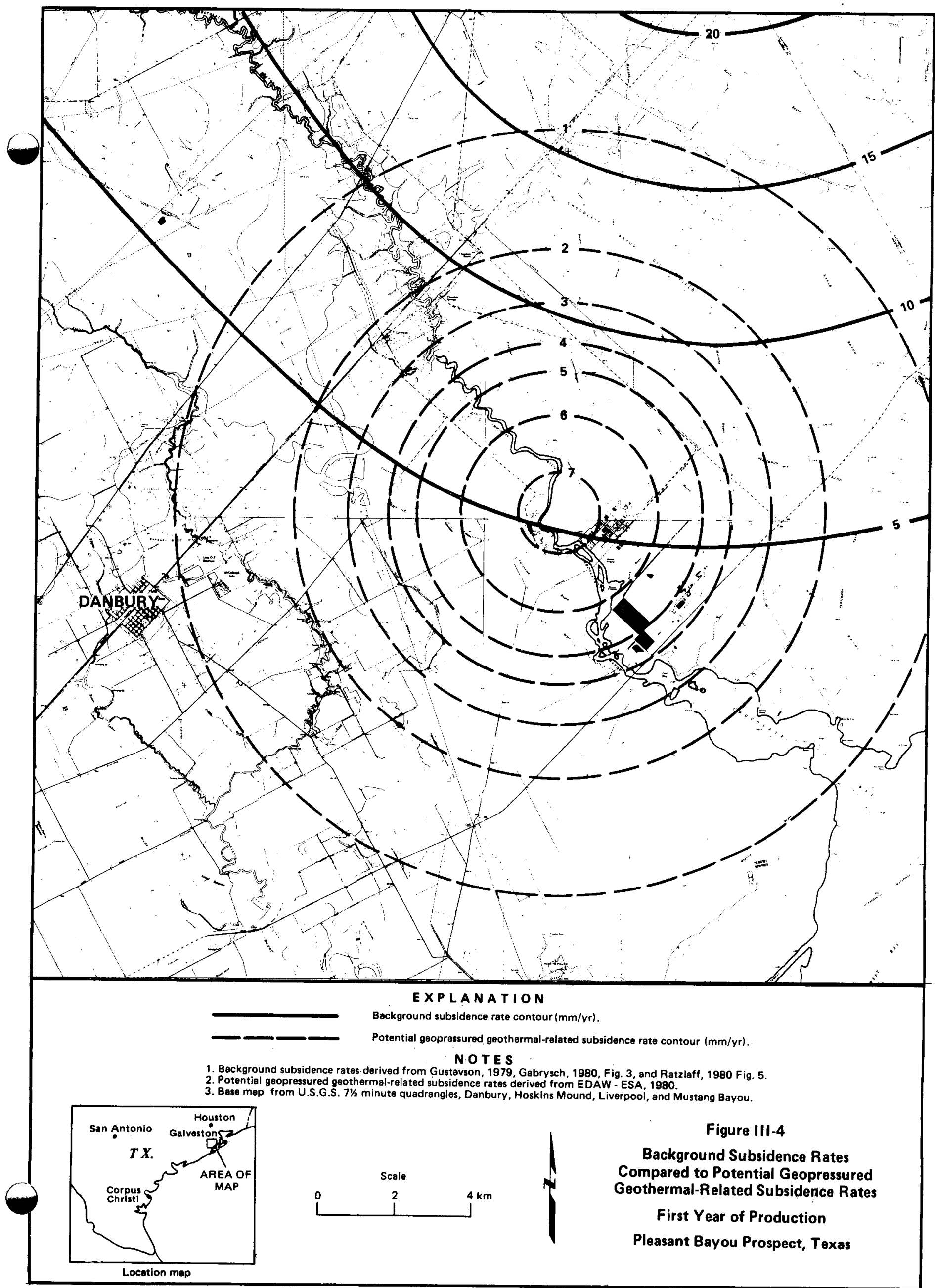




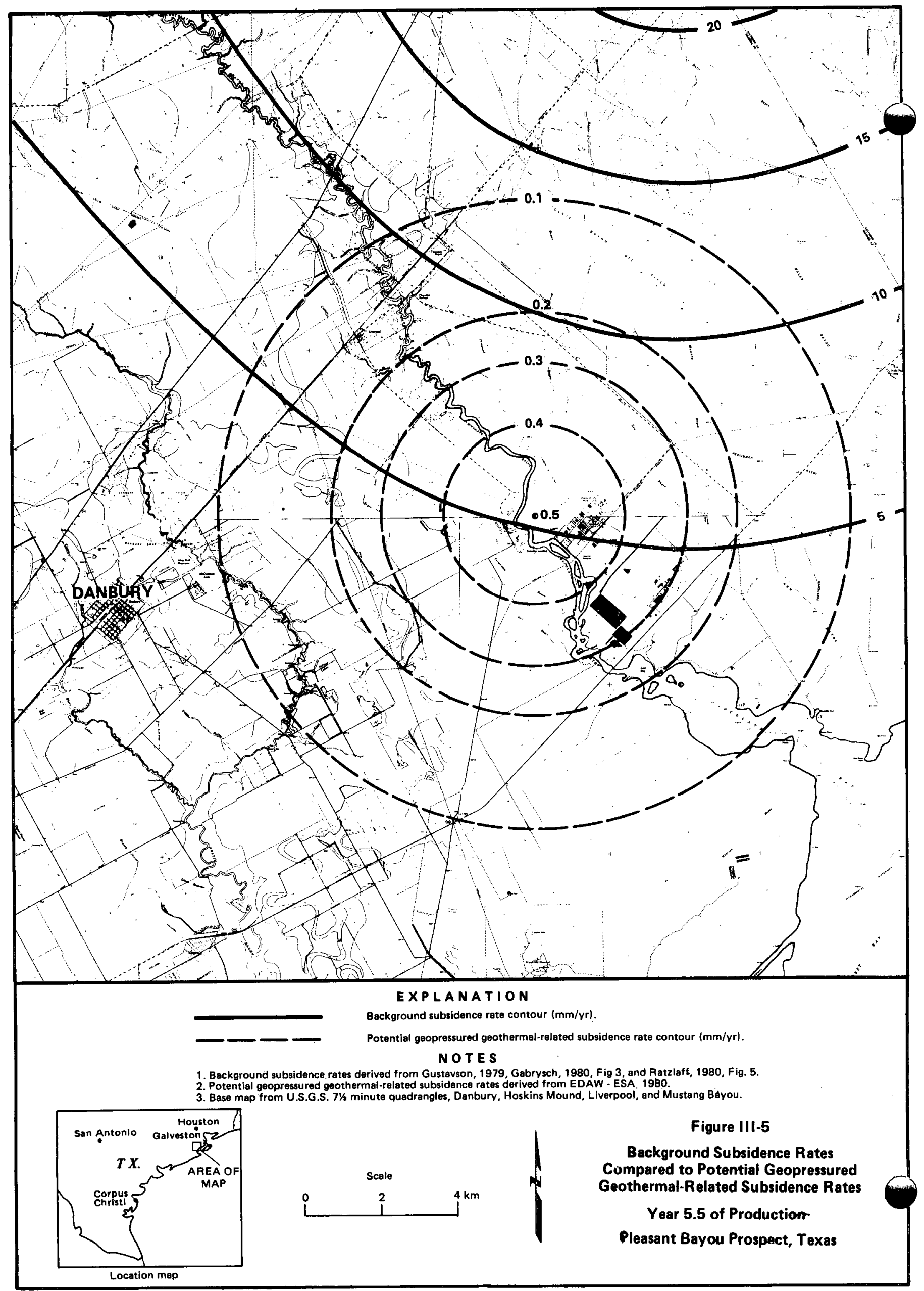




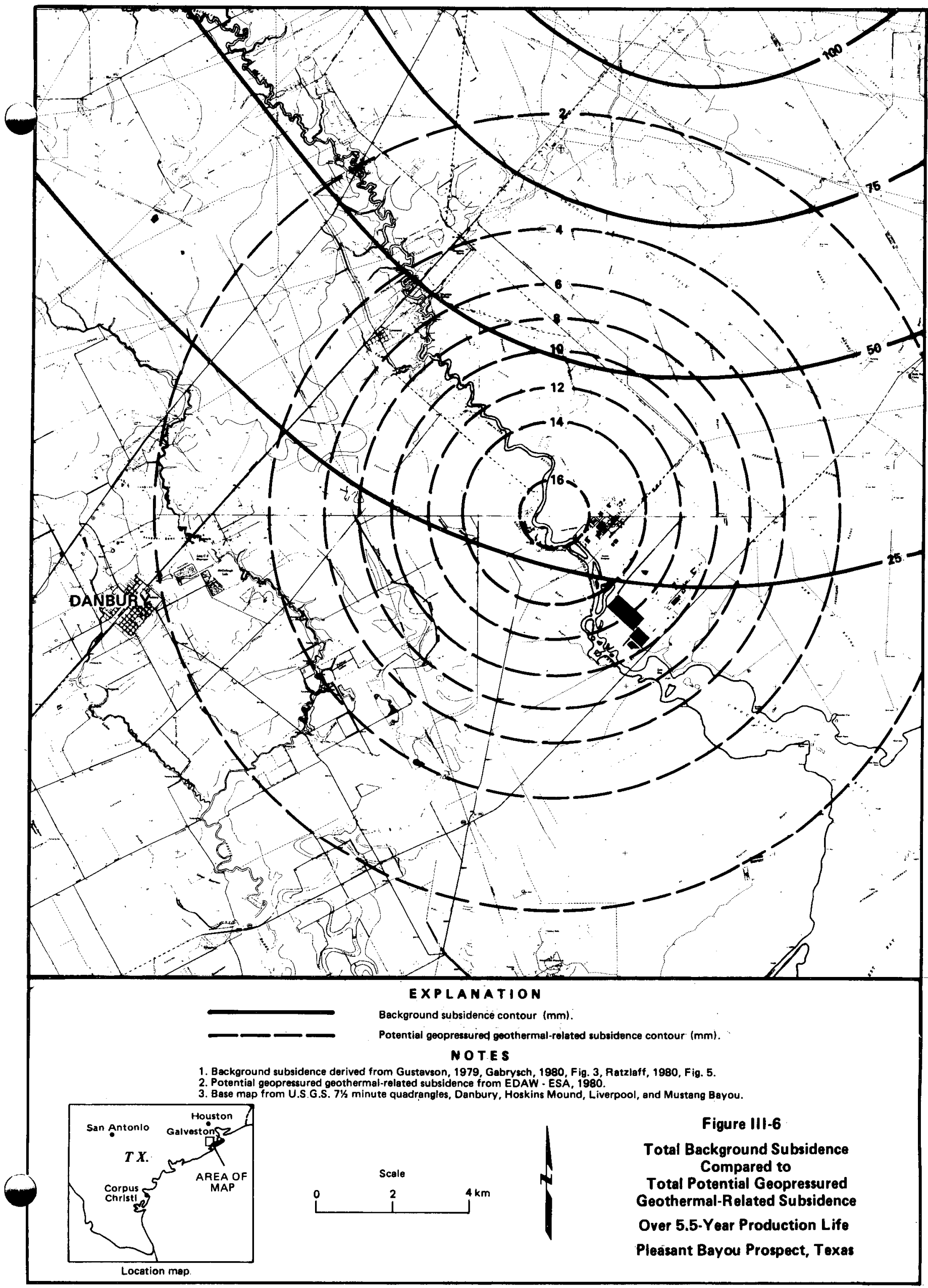




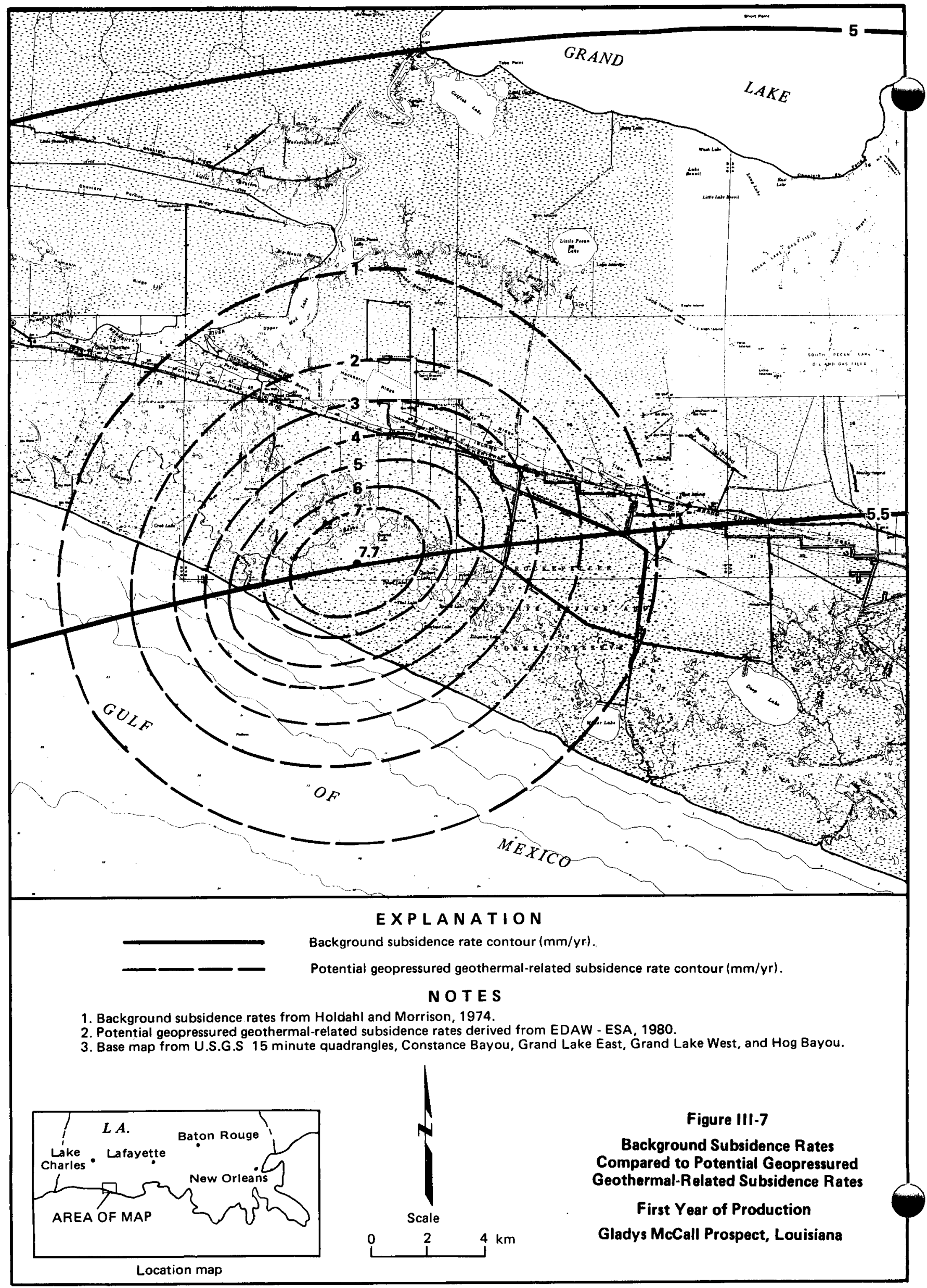




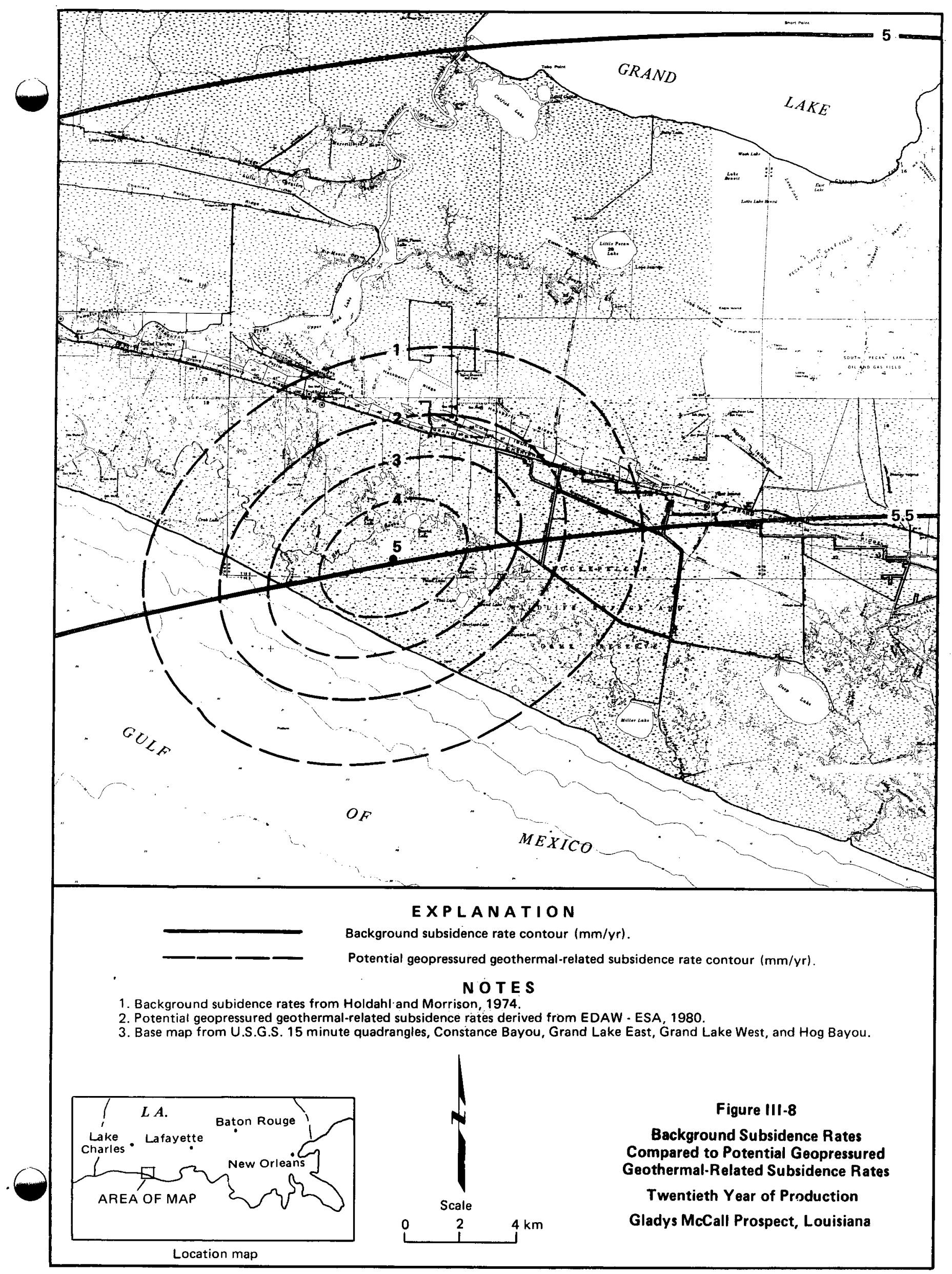




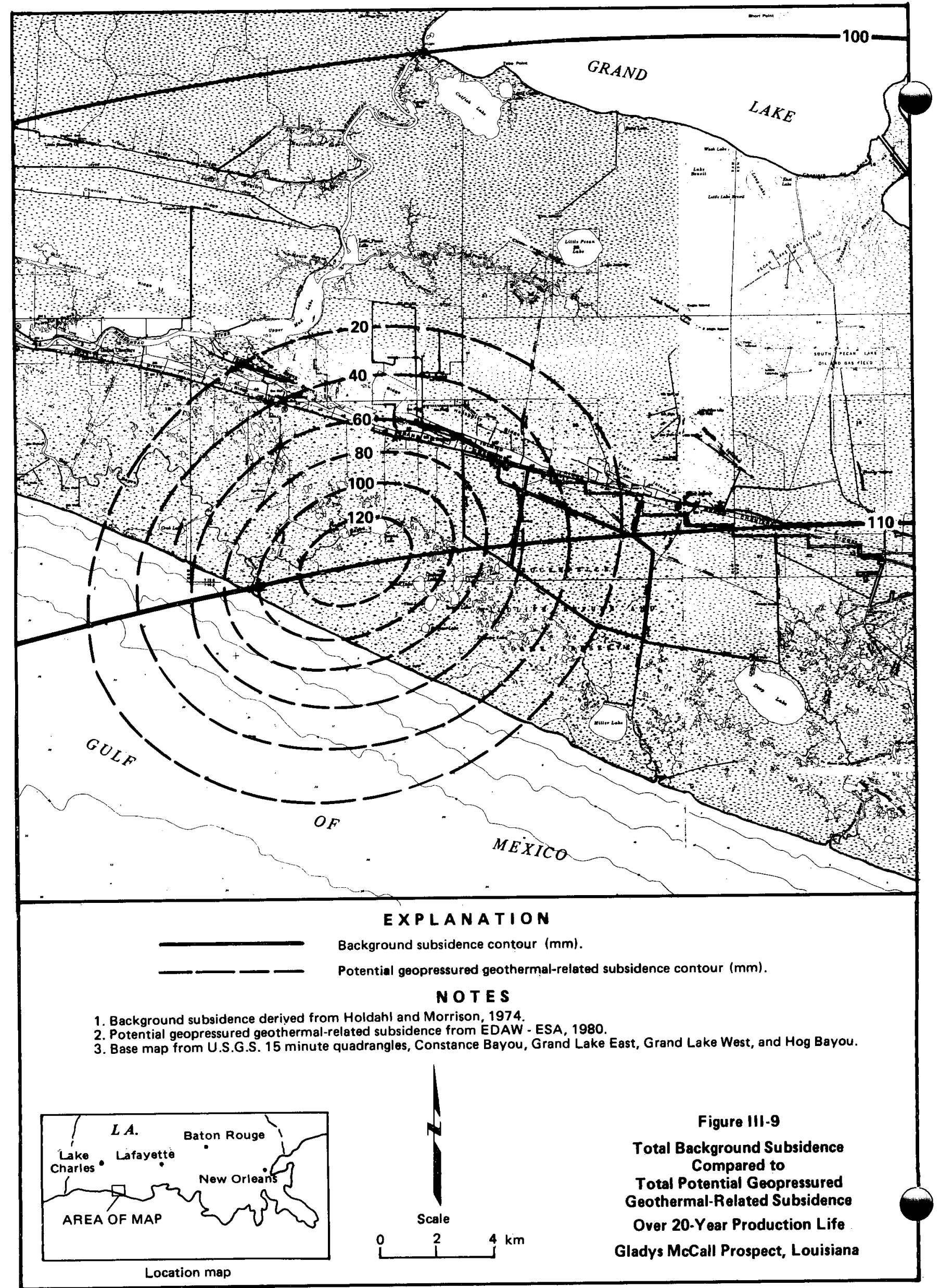




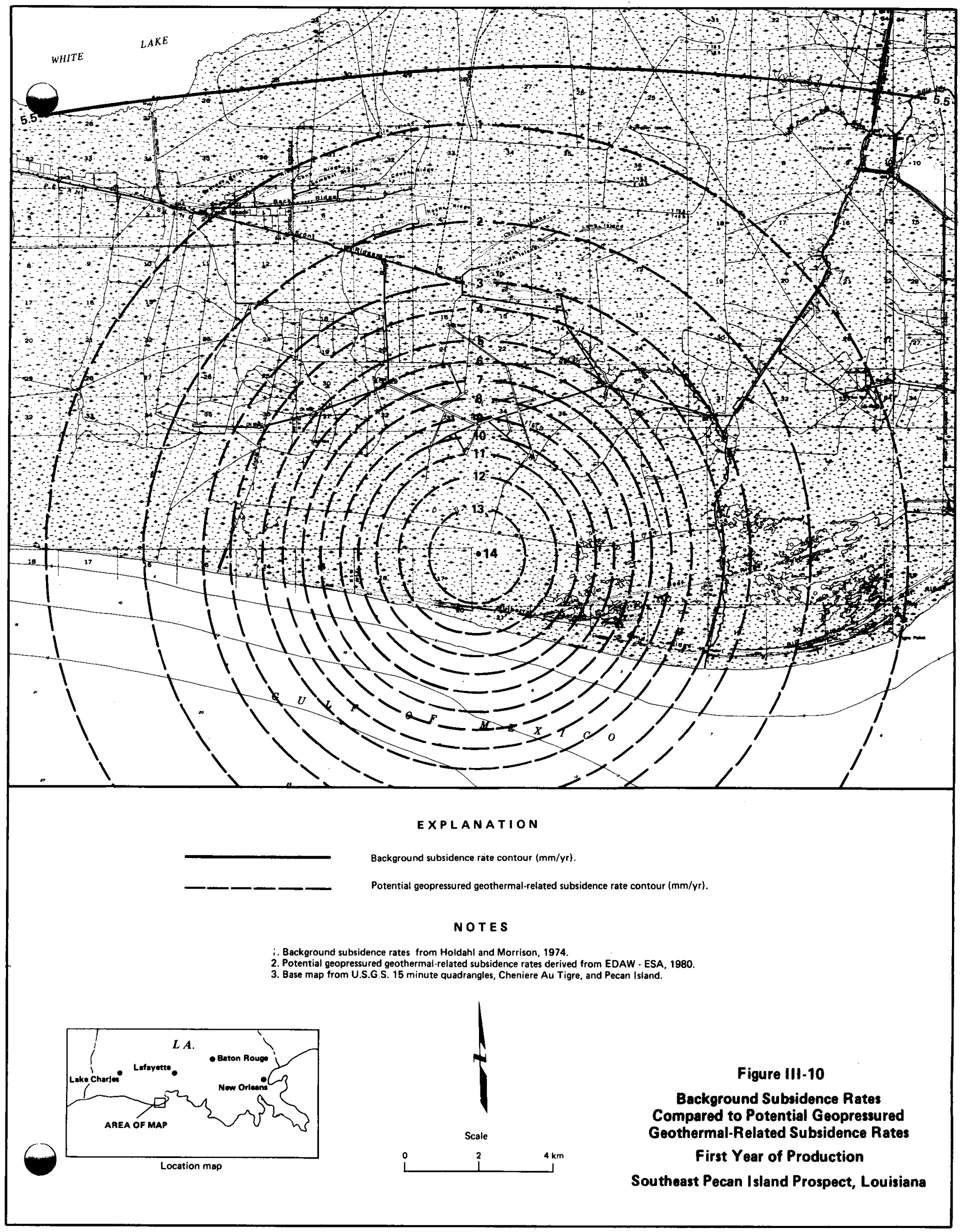




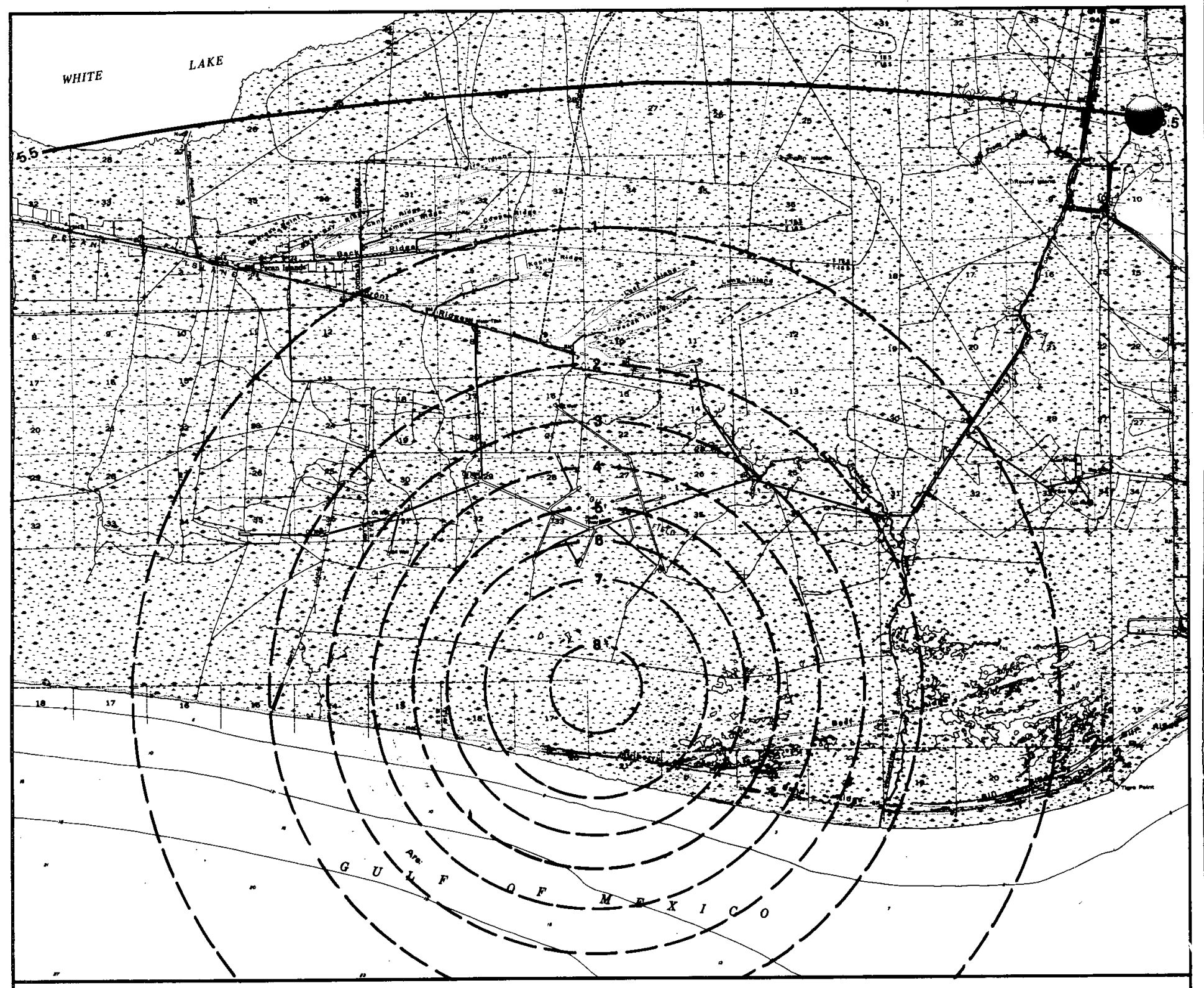

EXPLANATION

Background subsidence rate contour $(\mathrm{mm} / \mathrm{yr})$

Potential geopressured geothermal-related subsidence rate contour $(\mathrm{mm} / \mathrm{vr})$.

NOTES

1. Background subsidence rates from Holdahl and Morrison, 1974

2. Potential geopressured geothermal-related subsidence rates derived from EDAW - ESA, 1980

3. Base map from U.S.G.S. 15 minute quadrangles, Cheniere Au Tigre, and Pecan Island.

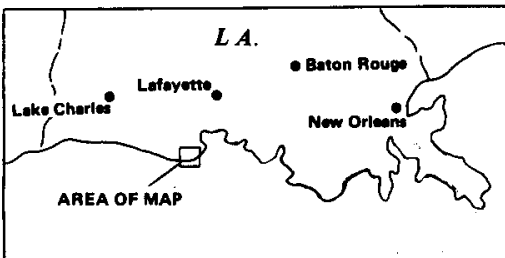

Location map

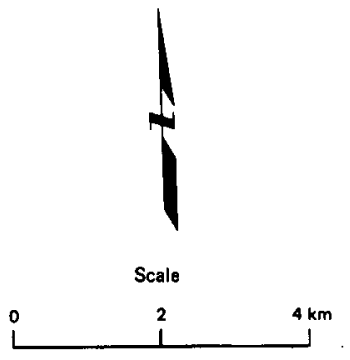

Figure III-11

Background Subsidence Rates Compared to Potential Geopressured Geothermal-Related Subsidence Rates

Twentieth Year of Production

Southeast Pecan I sland Prospect, Louisiana 


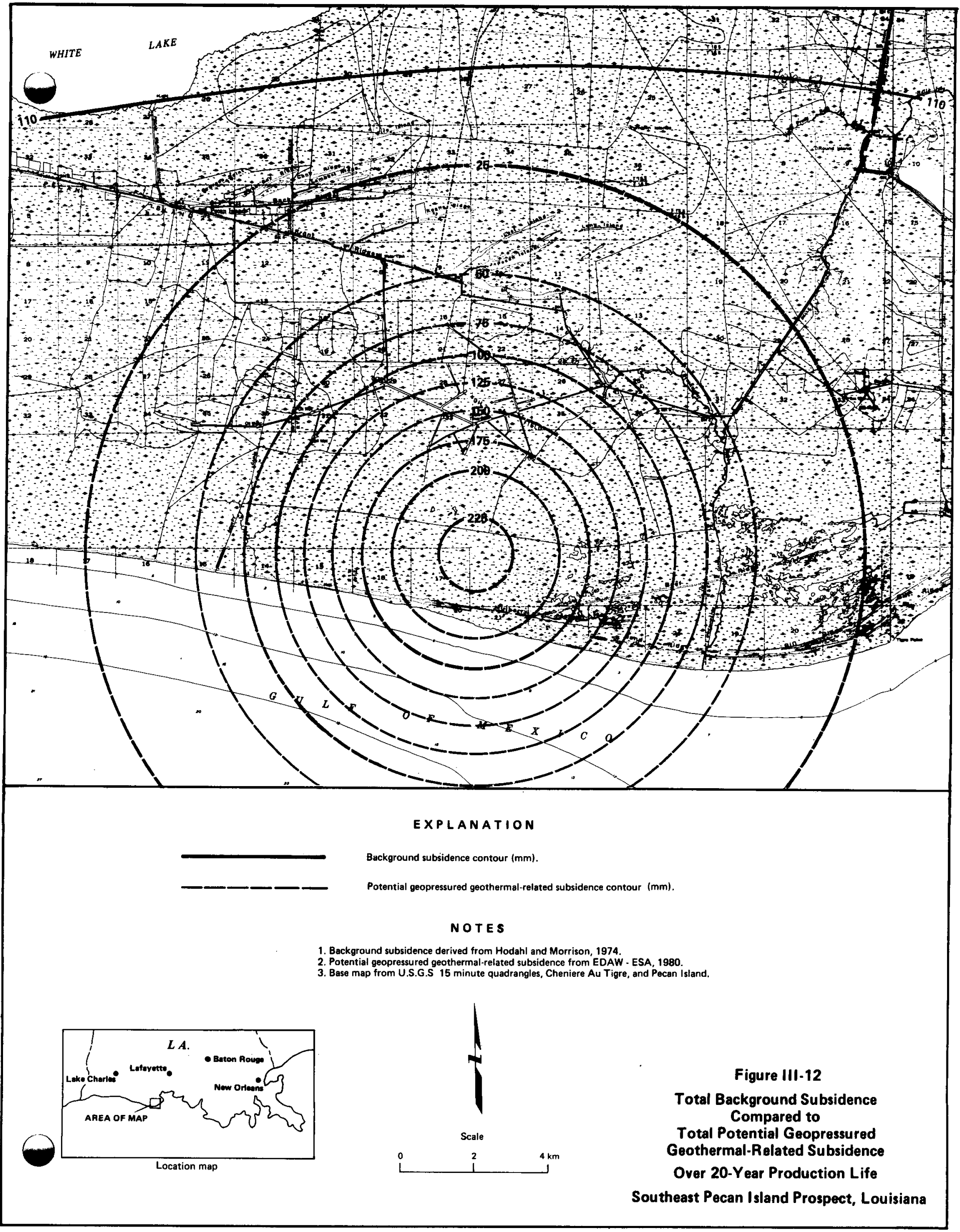




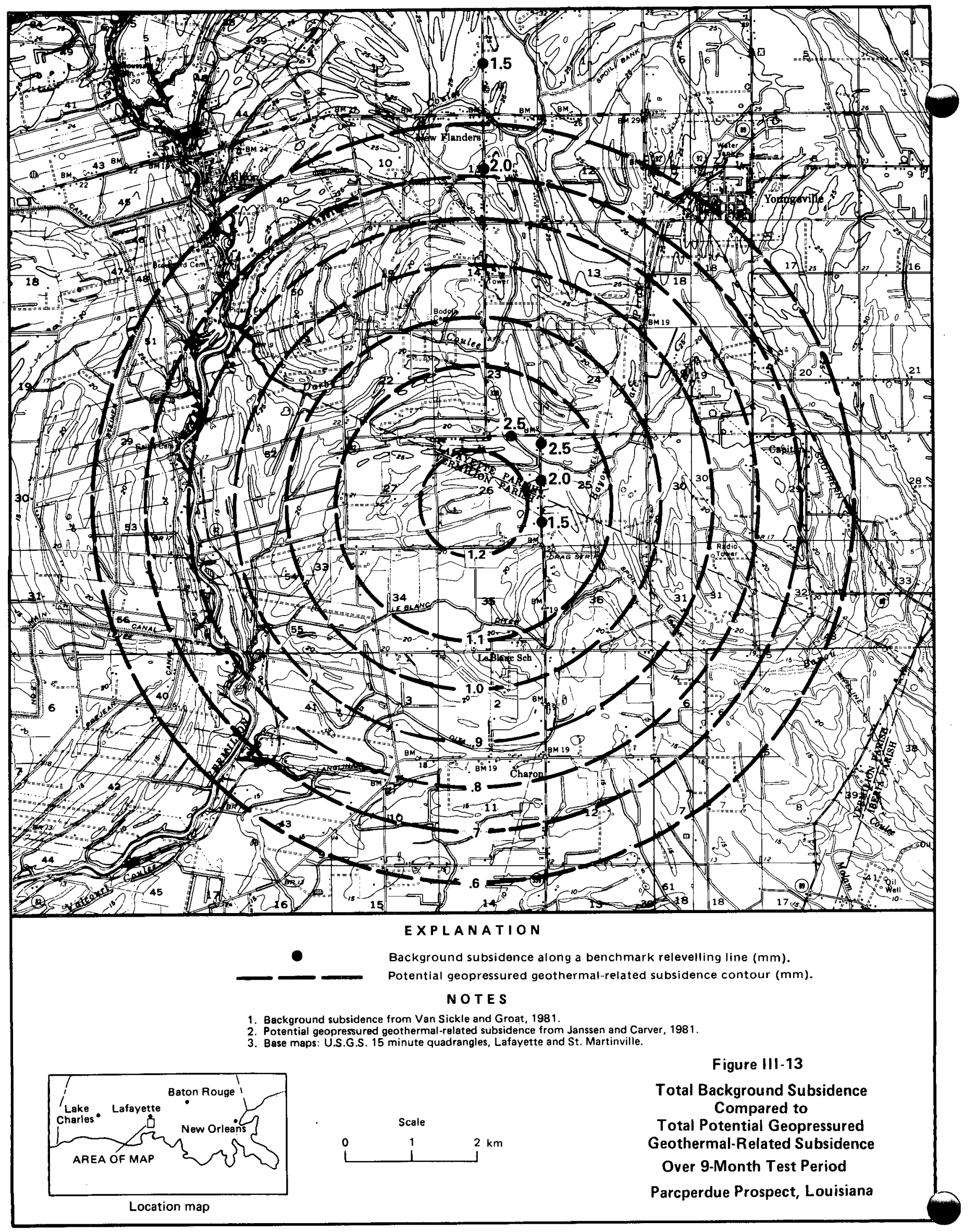



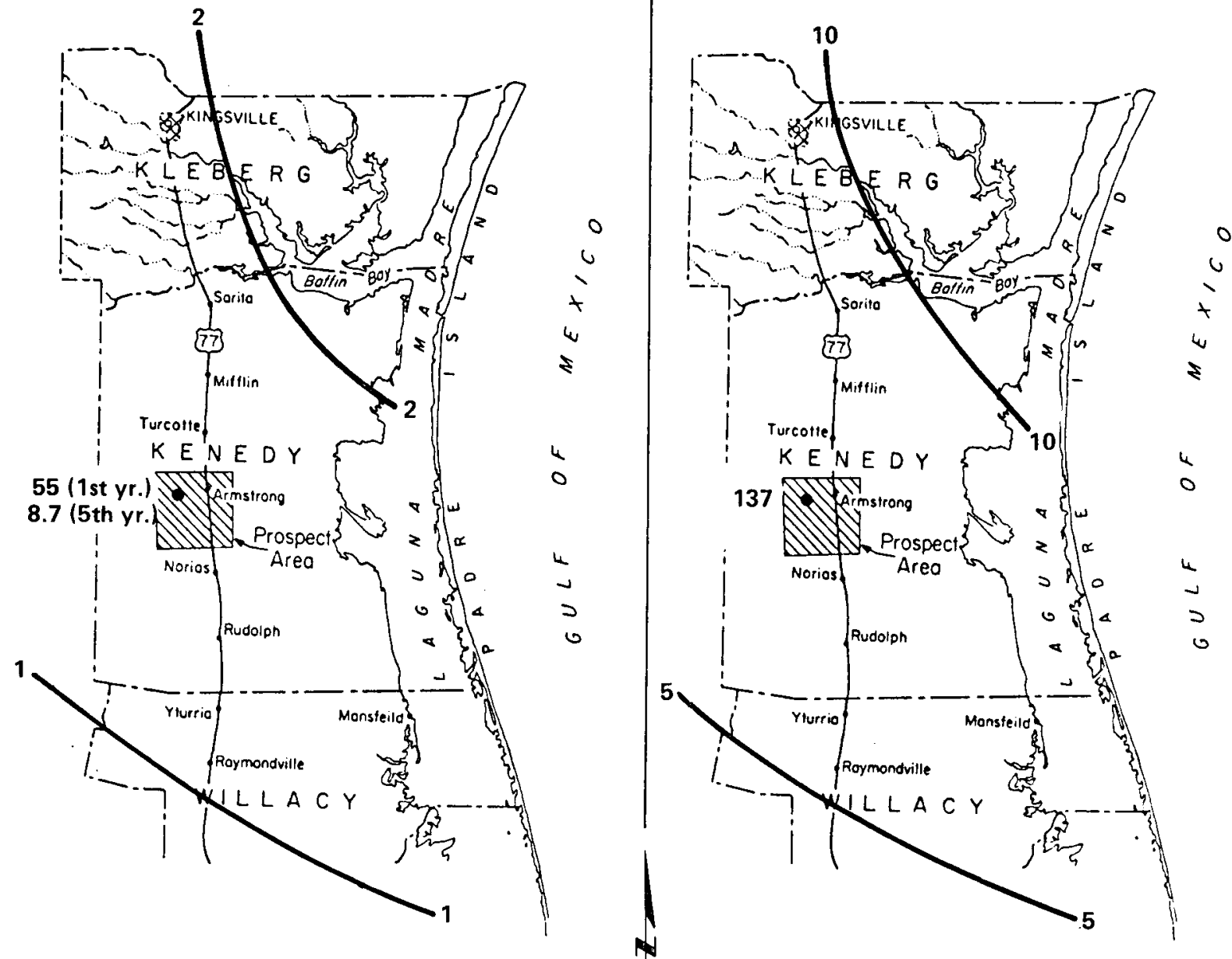

A.

Background Subsidence Rates Compared to Geopressured Geothermal-Related Subsidence Rates

First and Fifth Years of Test Period

Armstrong Prospect, Texas

EXPLANATION

Background subsidence rate contour ( $\mathrm{mm} / \mathrm{yr}$ ).

55

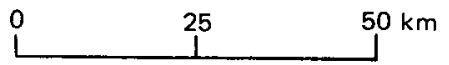

B.

Total Background Subsidence Compared to Total Geopressured Geothermal-Related Subsidence

Over 5-Year Test Period

Armstrong Prospect, Texas

\section{EXPLANATION}

Potential geopressured geothermal related subsidence rate at site $(\mathrm{mm} / \mathrm{yr})$.

137 Potential geopressured geothermal related subsidence at site $(\mathrm{mm})$.

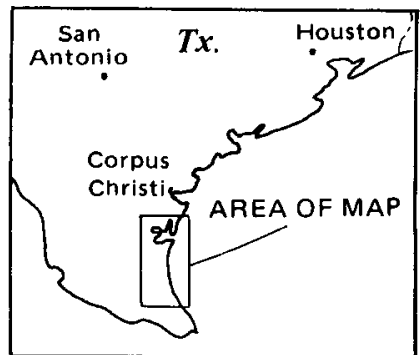

Notes:

1. Background subsidence from Holdahl and Morrison, 1974

2. Potential geopressured geothermal-related subsidence rate

derived from White and others, 1978.

Figure III-14

3. Base map from White and others, 1978, p. 148 
$\theta$ 30 


\section{ENVIRONMENTAL RESPONSE TO SUBSIDENCE}

In order to evaluate environmental response to subsidence, it is necessary to establish the relationships, or linkages, between subsidence phenomena and surficial processes and ecological systems (Figure IV-1).

The first step in this process is to identify and describe ground movements attributed to subsidence. The second step is to determine the extent to which these ground movements can affect the geohydrologic regimes that dictate the biological character of a given region. The third step is to identify the potential occurrence and severity of ecosystem perturbations resulting from altered geohydrologic regimes. This step involves describing existing regional habitats or ecosystems, identifying those factors affecting the component biological communities, and evaluating the potential floral and faunal impacts. A stepwise discussion of this process is presented in the following sections.

\section{A. Subsidence-Related Ground Movements}

The following summary of subsidence-related ground movements is taken from Viets and others (1979). This summary is an oversimplification of the problem, in that the phenomena discussed here (and underlined in the next three paragraphs) as discrete events actually occur simultaneously and change in time as the subsidence bowl develops. More detailed information can be found in Viets and others (1979) and in EDAW-ESA (1980).

The removal of water, gas, or oil, or the mining of solids from below the ground surface, can result in the formation of a subsidence bowl, a depression in the ground surface which develops in response to subsurface compaction (Figure IV-2). The profile of this vertical settlement or subsidence bowl generally depends on the local geology and the depth and areal extent of the material removed as well as the nature of the subsurface materials being withdrawn.

As the subsidence bowl deepens, tilting of the ground surface toward the center occurs in most parts of the bowl, except at the edge and in the center where the surface remains in its original orientation. The developing curvature of the bowl introduces strain and horizontal movement in the ground surface with all 


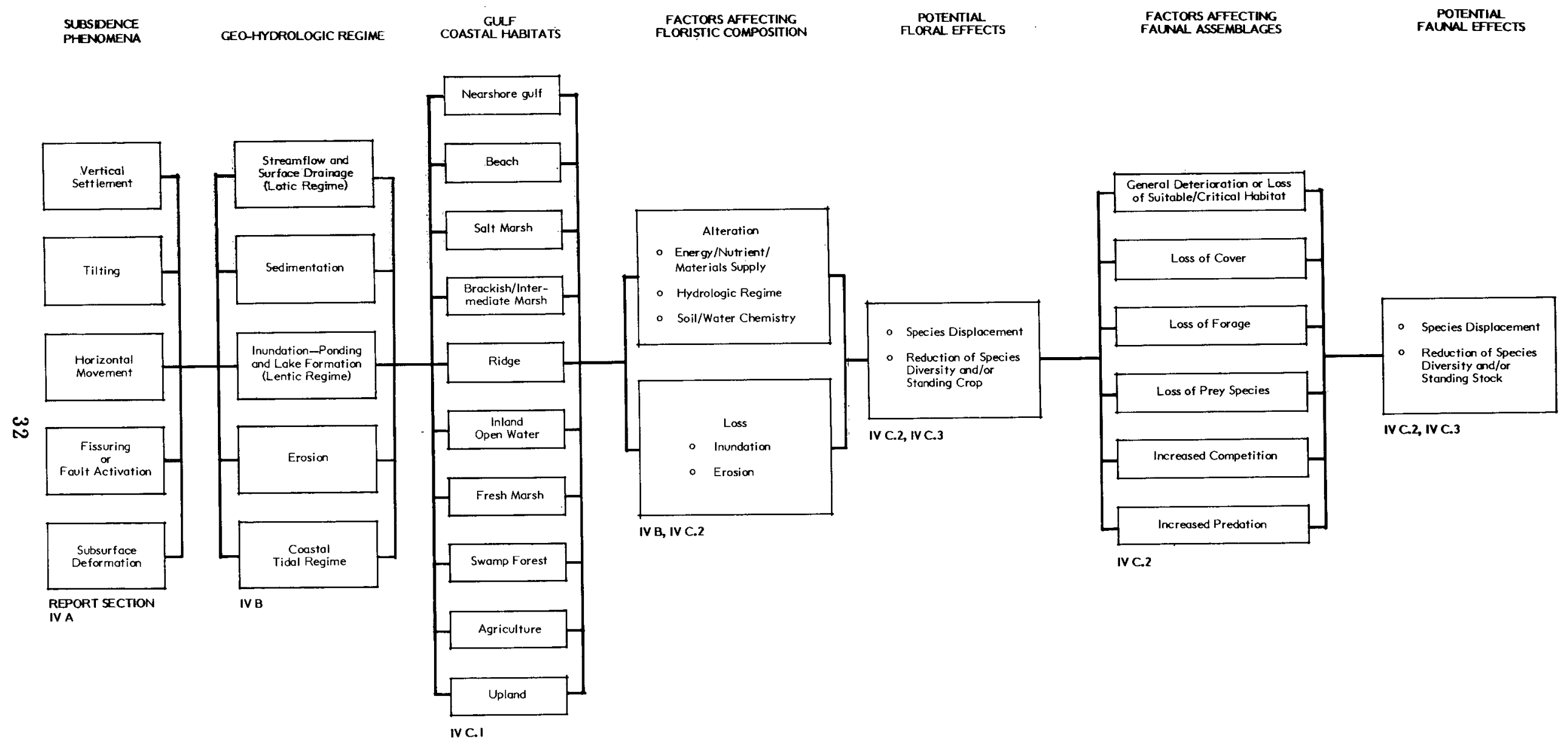

Figure IV-1 Flowchart Depicting the Potential for Adverse Impacts Due to the Linkages Between Subsidence Phenomena, Surficial Between Subsidence Phenomena,
Processes, and Ecological Systems 

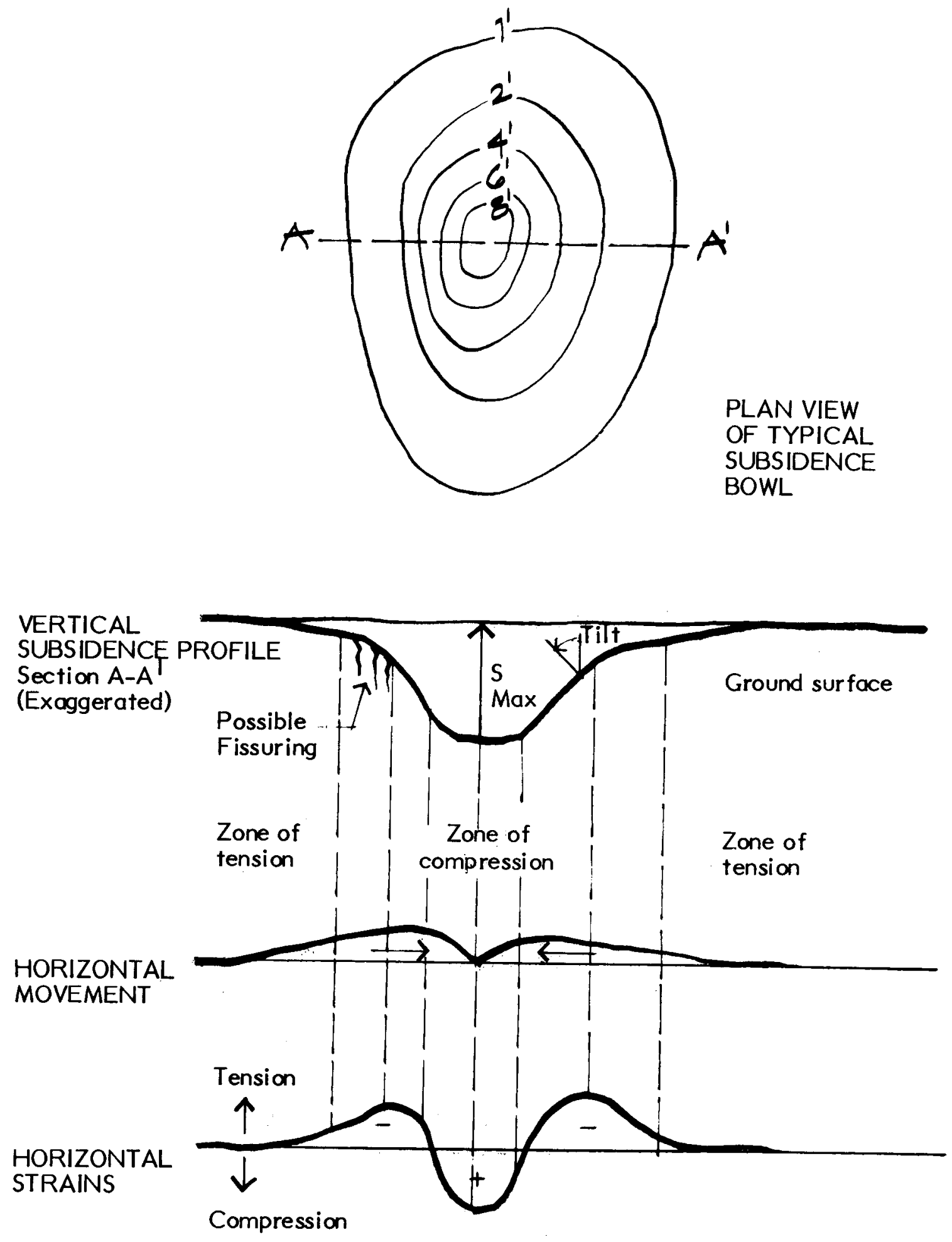
points on the ground surface within the bowl being displaced toward the center. In the outer part of the bowl, the surface is in tension and in the middle of the bowl, the surface is in compression. If the tensional strains in the outer portion of the bowl become large enough, tension cracks or fissures in the ground surface may result. Fissuring may also occur within the bowl at locations such as existing faults, where the vertical subsidence is concentrated due to some subsurface discontinuities.

In addition to surface alterations, both vertical and horizontal subsurface deformations occur. Vertical deformations occur within the zones of fluid withdrawal due to vertical compaction of the geologic formations and within the overlying materials as they subside because of the loss of support. Horizontal movements and strains develop below the surface just as they do at the surface. These vertical and horizontal deformations may be relatively uniform or they may be concentrated along geologic discontinuities and pre-existing faults.

\section{B. Effects of Subsidence on Surficial Processes}

The surficial processes and regimes which are most vulnerable to the effects of subsidence phenomena include: stream flow and surface drainage (lotic regime), sedimentation, ponding and lake formation (lentic regime), erosion, and tidal flow.

To discuss the potential alterations of these processes or regimes resulting from discrete subsidence phenomena is at best difficult and necessarily artificial. Such alterations result not only from vertical settlement but also from surface tilt, fissuring, horizontal land movement, and subsurface deformation, all occurring simultaneously to produce the effects perceived. Thus, in following the discussion below, it is necessary to keep in mind the dynamic and complex interrelationships that must be occurring for these effects to be manifested. A major source of information for this discussion was Viets and others (1979).

The effects of vertical settlement on surface stream flows and drainage channels are numerous and complex. The formation of a subsidence bowl beneath a streambed acts as a catch basin, collecting water at a low point on the stream profile. Over-bank flooding results if the capacity of the stream channel is exceeded, inundating surrounding lands and creating a new or extended floodplain. 
Ponding of water at one point along the stream increases the rate of sediment deposition in that portion of the stream, reducing the amount of sediment discharged downstream.

Land surface tilt has similar effects on stream flows and drainage patterns. Tilting can result in an increase in the gradient of a streambed with a commensurate increase in the rate of water flow, stream scouring, and erosion through the affected portion of the stream. A gradient decrease tends to have the opposite effect with lower flow rates and greater sedimentation. Tilting over considerable horizontal distances alters surface drainage patterns in areas of low topographic relief. Disruption of surface drainage can result in the formation of new ponds and marshes as well as the abandonment of existing wetlands. In this respect, fissuring or fault activation can have similar effects by producing a subsidence block which may cause diversion of existing stream flow, drainage patterns, and deltaic distributaries.

The effects of the abandonment of a deltaic distributary system, regardless of the cause, can be significant, as described by Morgan (1967) and summarized here. With the abandonment of a deltaic distributary system, sedimentation ceases, but subsidence continues and becomes the dominant modifying process (Figure IV-3). The more massive distributary levees tend to subside more rapidly than the adjacent marshes, consequently dragging down the adjacent marsh to form elongated open ponds or levee flank depressions paralleling the outer levee margin. With continuing subsidence, aided by wave erosion of their banks, the levee flank depressions as well as lakes and ponds gradually enlarge and coalesce. In a comparatively few years, marshy interdistributary basins thus become open bays connected with the Gulf.

Subsidence beneath standing water bodies such as large ponds, lakes, reservoirs, or bays increases their depth and extent, of ten at the expense of adjacent habitat. Open water bodies carry greater tidal and wind forces. Increased wave fetch across the expanding water body accelerates bank erosion (Morgan, 1972) and loss of adjacent habitats.

Subsidence and the apparent rise in groundwater level may also have serious repercussions (Viets and others, 1979; Figure IV-4). The apparent rise in the 

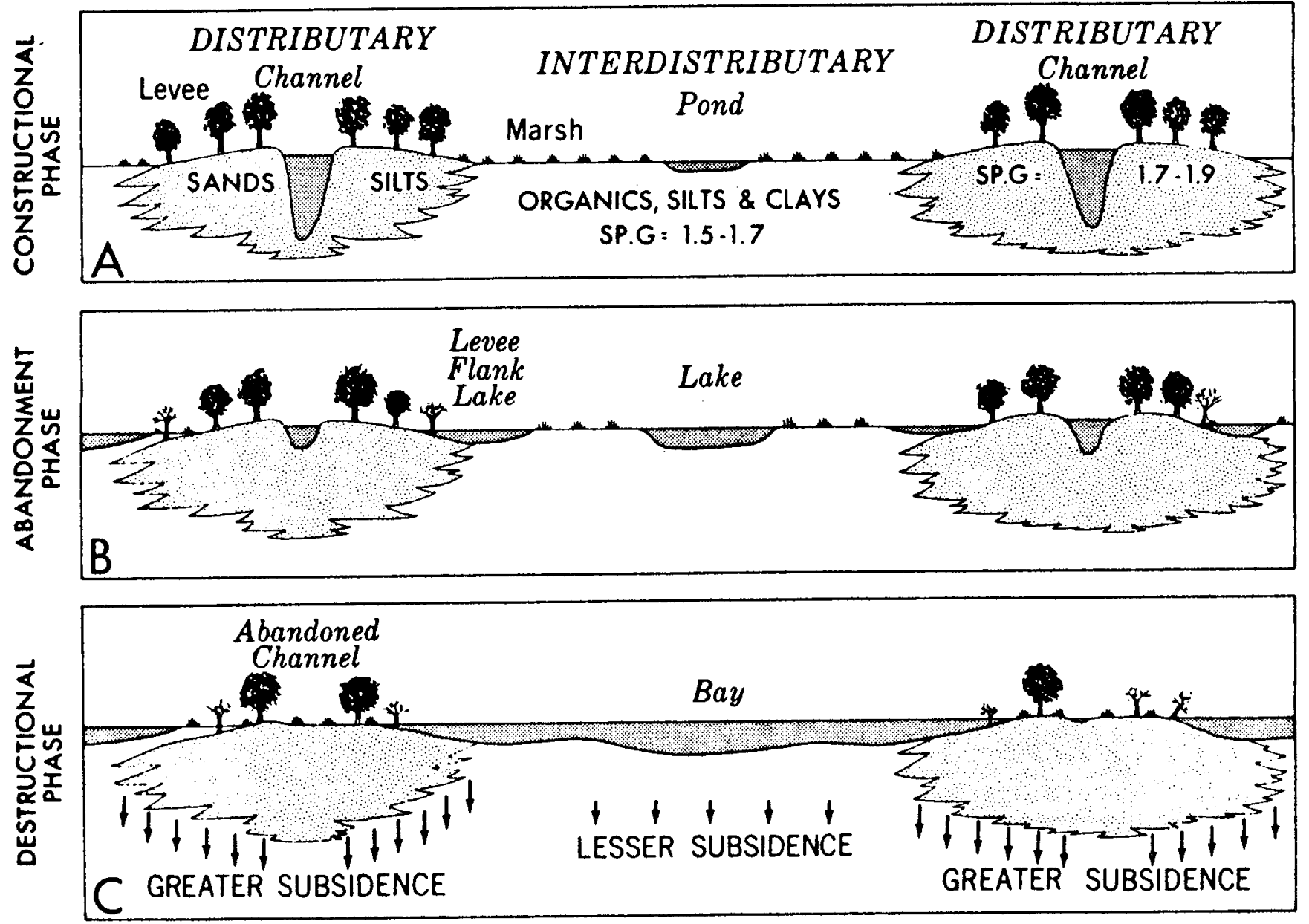

SP. G. = specific gravity 

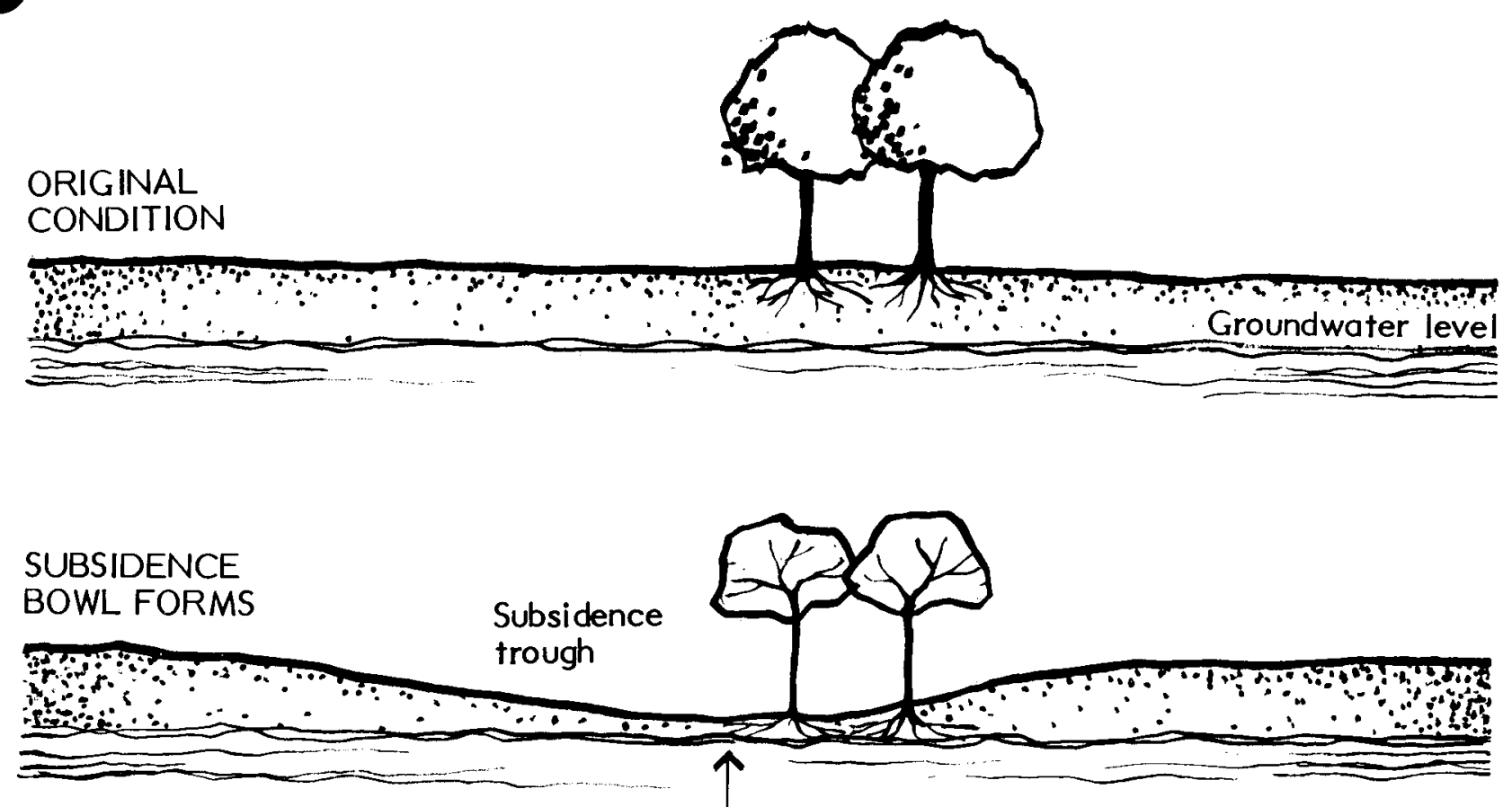

Rising water level drowns plant roots, interferes with subsurface drainage, and reduces agricultural productivity

MAJOR

SUBSIDENCE

BOWL FORMS

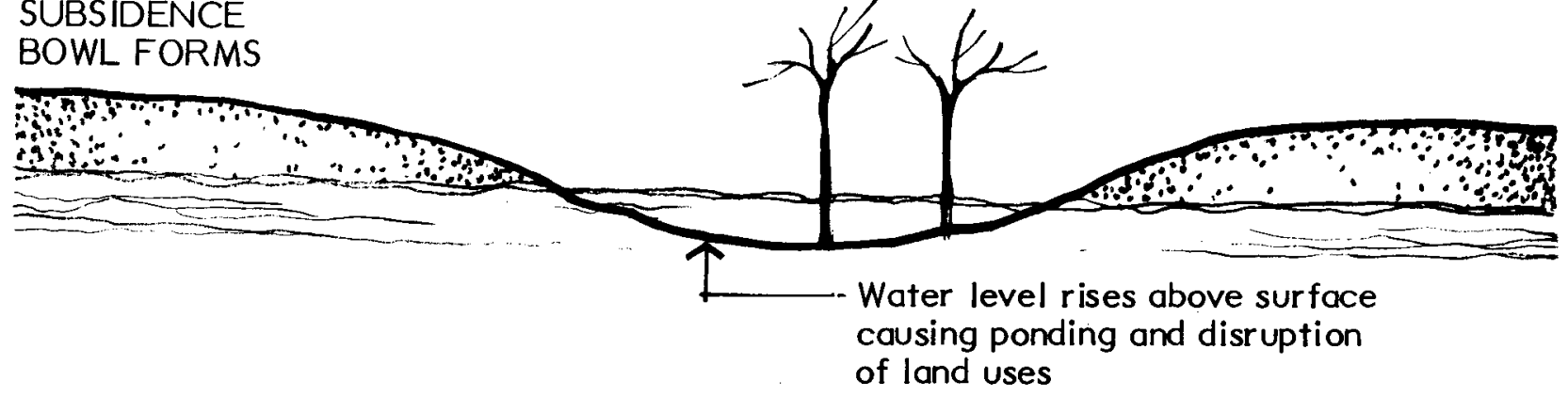


water table can disrupt subsurface drainage and drown root systems. In severe cases where the land surface subsides below the level of the existing water table, ponding will occur.

The vertical subsidence of the land surface at or near the Gulf coastline permits tidal encroachment and land loss resulting from permanent inundation. Subsidence of barrier islands, coastal marshes, and other natural storm buffers is particularly significant as their ability to reduce storm impact is reduced. Subsidence beneath barrier islands widens inlets and tidal passes between islands, allowing greater access during storms. The subsidence and subsequent submergence of marshland reduces the ability of the coastal marshes to absorb storm tidal force. The acceleration of shoreline erosion attributable to subsidence permits tidal intrusion further inland, accompanied by increasing salinities and alteration of marsh floristic composition.

\section{Effects of Subsidence on Gulf Coast Ecosystems}

\section{Gulf Coast Habitats}

The following discussion describes the characteristic habitats of the TexasLouisiana Gulf Coast. These habitats have been organized into ten categories: Nearshore Gulf, Beach, Salt Marsh, Brackish/Intermediate Marsh, Ridge, Inland Open Water, Fresh Marsh, Swamp Forest, Agriculture, and Upland. The narrative descriptions are accompanied by a diagrammatic habitat cross-section (Figure IV5). This depiction should not be viewed as absolute either in sequence or content but rather as representative and sum mational.

It is not suggested that the habitat descriptions as presented here occur throughout the Texas-Louisiana Gulf Coast. In fact, there is considerable variation among local physiographic units. For example, the occurrence of upland prairie grassland is extensive in coastal Texas, whereas coastal Louisiana is dominated by various forms of emergent vegetation. The Chenier Plain of southwestern Louisiana differs considerably in habitat sequence from that of the BarrierStrandplain system of Texas. Likewise, the active Deltaic Plain of southeastern Louisiana does not exhibit the same characteristics as the Chenier Plain region. 
The approach here has been to describe the major characteristic features of the various habitat types including the dominant floristic composition and faunal assemblages. The purpose of identifying the dominant biological assemblages for each habitat has been well-stated by Copeland (1970): "Such an inventory of components alone gives little idea of the way the system works, but the presence of characteristic species with known special adaptations suggests the nature of the system."

One habitat that is not discussed here is Impounded Marsh. Although this marsh type represents (in terms of areal extent) a significant proportion of the available Gulf coastal habitat, the species and assemblages that comprise and use this habitat are characteristic of the other marsh types discussed in this report.

The habitat summaries presented here were developed primarily from the following four sources: An Ecological Characterization Study of the Chenier Plain Coastal Ecosystem of Louisiana and Texas, Volumes I and II (Gosselink and others, 1979); Environmental Geologic Atlas of the Texas Coastal Zone - GalvestonHouston Area (Fisher and others, 1972); Cooperative Gulf of Mexico Estuarine Inventory and Study, Louisiana (Perret and others, 1971); and Community Structure and Carbon Budget of a Salt Marsh and Shallow Bay Estuarine System in Louisiana (Day and others, 1973).

\section{a. Nearshore Gulf}

The boundary area of the nearshore Gulf has been defined as "all water between the coastline and the 9 meter depth contour in the Gulf of Mexico" (Gosselink and others, 1979). This area definition consequently includes open bays, estuaries, mudflats, grassflats, and the intertidal zone.

The southeastern Louisiana coastline is very discontinuous because of the active deltaic processes occurring in that area. As a result, there have developed numerous bays, estuaries, and tidal inlets. The coastline of southwestern Louisiana in contrast is somewhat older and more defined (Perret and others, 1971). As a result of this relatively continuous shoreline, there are fewer bays and inlets. For much of the Texas coastline, the nearshore Gulf can be defined as extending 

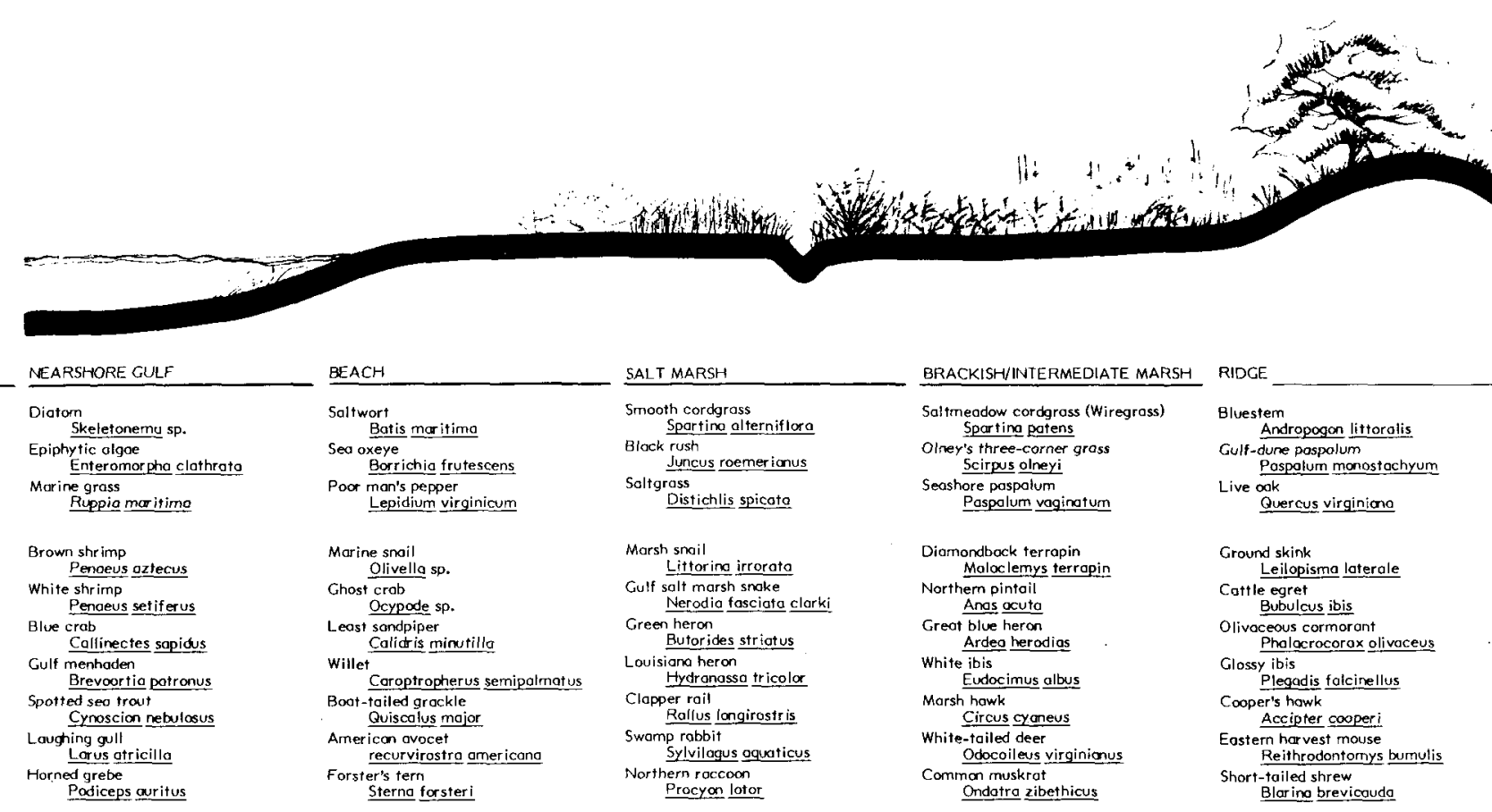

HABITATS

PRODUCERS

CONSUMERS
BEACH

Salt wort
Batis maritima

Borrichia frutescen
Ped oxeye

man's pepper
Lepidium virginicum

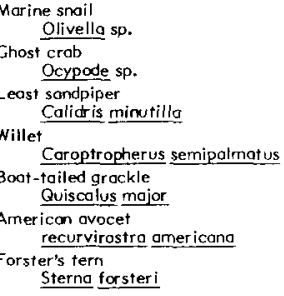

Distichlis spicoto$$
\text { Littorina irrorata }
$$

Nerodia fasciata clo

isiana heron

Rallus longirustris

ylvilogus oquaticus

Procyon lotor
RIDGE

Bluestem

Andropogon littoralis

dure pospol um
Paspalum monastochyum Live ook

Quercus virginiono

Ground skink Leilopisma laterale

Cottle egret
Bubulcus ibis

Olivaceous cormorant
Phalgcrocorax olivaceus

Glossy ibis

Plegadis faicinellus

Cooper's hawk

Accipter cooperi

Eostern har vest mouse
Reithrodontornys bumulis

Short-tailed shrew

Blarino brevicauda 


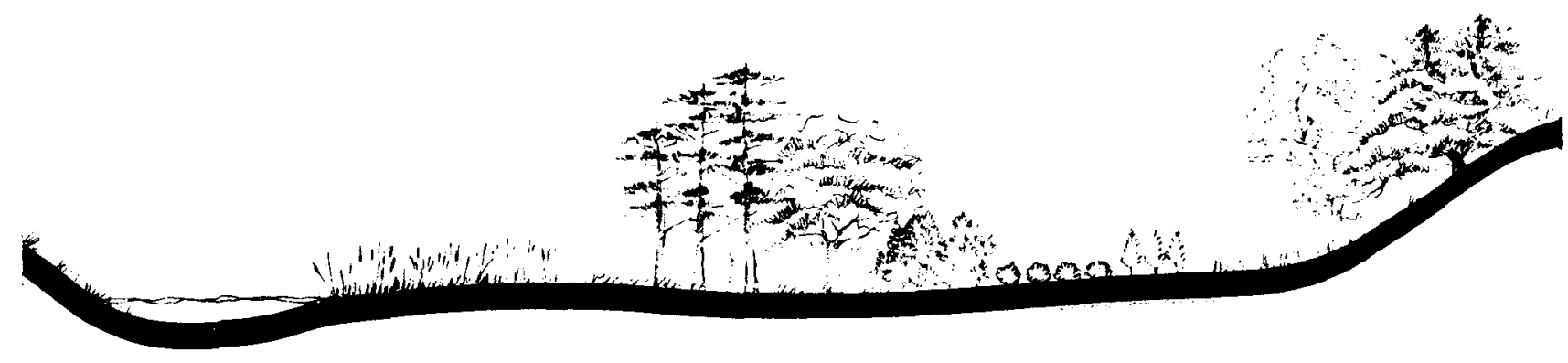

INLAND OPEN WATER

Benthic algoe
Euglend $5 p$

Pennate Diatom

Pinular ia biceps

Dinoflagellate
Procont:

Procontrum gracile

Diamondback water snake
Nerodia rhombifera

Btue catfish

Ictalurus furcotus

Spotted gar

Lepisosteus oculatus

eckled worm e

Mot My waphis punctatus

Ams fulvit

Anos fulvigula

Pelecanus erythrorhynchus

Nearctic river ofter
FRESH MARSH

Maidencane

Panicurr hemitomon

Soggittar io folcato

Saltmeadow cordgrass (Wiregrass)

Spartina patens

Gulf coost tood
Bufo vollice

American alligator

Alligator mississippiensi

Little blue heron

Florida coervlea

Least bittern

Ixobrychus exilis Nyctanossa violocea
Noton

Nutrio

Red wolf
Conis rufus
SWAMP FOREST

Water fupelo

Nyssa aquatica

Water ook

Baldc pereus nigro

Toxodium distichum
Talderess

Squirrel treefrog

Hyla squirello

Cottonmouth

Agkistrodon piscivorus

Pileated woodpecker Dryocopus pileutus

Great horned ow

Bubo virginianus

Lle bat

Virginio opossurealis

Oidelphis virginiono
Oing

Bobeat Lynx rufus
AGRICULTURE

Rice Fields

Pasture/grazing

Domestic croplands

Central newt

Imus viridescens

Glossy crayfish srake
Regina grahamii

Conardo goose

Bronto conadensis

Red-winged blackbird

Agcloius phoeniceus

Corws brachyrynchos Marsh rice ra

Oryzomys palustris

roy fox

Urocyon cinereoor genteus
UPLAND

$$
\begin{aligned}
& \text { Indiangrass } \\
& \text { Loblorghastrum sp. } \\
& \text { Pinus pin taeda } \\
& \text { Live-ock } \\
& \text { Quercus virginiona }
\end{aligned}
$$

Prairie king snake Lampropeltis colligaster

Blue jay

Cyanocitto cristata

Red-shouldered howk

Buteo lineotus

Common screech
Otus osio

Turkey vulture

Cathartes aura

Gray squirrel

Sciurus carolinensis

Northern raccoon
Procyon lotor

Figure IV-5 Diagrammatic Habitat Cross Section 
seaward from the barrier-strandplain beaches. The coastal bays and estuarine systems of this region are semi-enclosed by the barrier-strandplain system and thus, for the purposes of this report, are categorized as inland open waters.

The predominant producers in the nearshore Gulf are phytoplankton including diatoms (Asterionella sp., Navicula sp., Skeletonema sp.) and dinoflagellates (Ceratium sp., Exuviaella sp., Gonyaulaux sp.). Production from marine grasses (Ruppia maritima, Thalassia testudinum, Diplanthera wrightii) and algae (Enteromorpha clathrata, Cladophera dalmatica) is less important.

The principal consumers are characterized by zooplankton; benthic invertebrates such as penaeid shrimp (Penaeus setiferus, $\underline{P}$. aztecus), marine snails (Melampus bidentata), oysters (Crassostrea virginica) and blue crab (Callinectes sapidus); and fish such as gulf menhaden (Brevoortia patronus), spotted sea trout (Cynoscion nebulosus) and red drum (Sciaenops ocellata). In general, fish species diversity is lower in comparison to inland open water as a result of the lower habitat diversity of the nearshore Gulf.

There are numerous fish-eating birds that utilize this habitat including the horned grebe (Podiceps auritus), black skimmer (․ㅡchops niger), laughing gull (Larus atricilla) and lesser scaup (Aythya affinis).

\section{b. Beach}

In the chenier and deltaic regions of coastal Louisiana there is typically a landward transition from beach to salt marsh. In the barrier-strandplain of coastal Texas, the Gulfward beach habitat grades landward into a beach ridgebarrier flat habitat. The functional significance of the beach habitat in either system is the buffering effect it has on adjacent habitats, partially protecting these areas from strong wind and tidal forces.

Plant production in the beach habitat is of ten limited by the availability of nutrients and freshwater. Typical vegetation includes saltwort (Batis maritima), sea-oxeye (Borrichia frutescens) and poor man's pepper (Lepidum virginicum). Resident vegetation and additional plant material deposited on beach sands by tidal action together serve as a food source for the beach meiofauna. The meiofaunal 
assemblage consists primarily of small detritivores and first-order consumers. These animals in turn provide a food source for higher order consumers.

While reptiles and amphibians are scarce in this habitat, birds are numerous. Shore birds such as avocets (Recurvirostra americana), sandpipers (Calidris minutilla) and willets (Caroptropherus semipalmatus) utilize the beach meiofauna and the infauna of adjacent tidal flats as a primary food source. Fish-eating birds of adjacent wetlands and the nearshore Gulf of ten use the beach

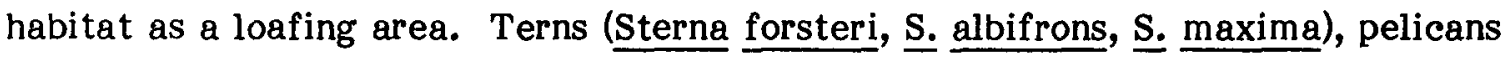
(Pelecanus erythrorhynchos), and gulls (Larus atricilla) are representative of this group.

\section{c. Salt Marsh}

The characteristic cheniers (ridges) of the southwestern Louisiana coastal chenier plain system tend to restrict the salt marsh distribution in this region to narrow bands along a generally continous shoreline. The salt marshes of the southeastern Louisiana deltaic plain are not so restricted and are considerably more expansive. In coastal Texas, salt marshes occur along the margins of bays, estuaries, and beach ridge-barrier flats.

Salinities characteristic of salt marshes tend to vary in response to the different components of the local hydrologic regime, including frequency of tidal inundation and freshwater inflows. In general, salinities are highest during late summer when rainfall is low and tides are high. Lowest salinities occur in spring during periods of peak freshwater inflows. Salinities that have been identified in the literature as representative of salt marshes include: 18-30 parts per thousand (ppt) (Cowardin and others, 1979), 12.4 ppt (Gosselink and others, 1979), and $18^{+}$ppt (Montz, 1977).

Elevational distribution of salt marshes also tends to vary with hydrologic regime and topographical features. For Davis Bay, Mississippi, Eleuterius and Eleuterius (1979) have described the marsh surface in the zone of smooth cordgrass (Spartina alterniflora), the dominant salt marsh halophyte, as occurring from 24 centimeters below mean low water (MLW) to 54 centimeters above MLW. Sasser 
(1977) found that in eastern Louisiana, marshes varied in elevation from approximately 9 centimeters below local mean sea level (MSL) to 9 centimeters above MSL.

Because of the saline regime of coastal salt marshes, this habitat supports the lowest floral species diversity of the wetland habitats. Gulf coastal salt marshes tend to be dominated by smooth cordgrass (Spartina alterniflora), with blackrush (Juncus roemerianus), saltgrass (Distichlis spicata), and saltwort (Batis maritima) being common.

Estimates of primary productivity for a Spartina alterniflora dominant salt marsh range from $750 \mathrm{~g} / \mathrm{m}^{2} / \mathrm{yr}$ to $2,600 \mathrm{~g} / \mathrm{m}^{2} / \mathrm{yr}$ (Kirby and Gosselink, 1976). Gosselink has elsewhere (1979) reported an annual productivity estimate of $2,200 \mathrm{~g} / \mathrm{m}^{2} / \mathrm{yr}$ for salt marshes in Louisiana. Of this net production, only a small percentage is consumed by grazers (Day and others, 1973). Smalley (1959) estimates that less than 10 percent of the emergent salt marsh vegetation is directly grazed, with the bulk of the primary consumption occurring through the detritus chain (Gosselink and others, 1979; Odum and de la Cruz, 1967).

Consumers that are characteristic of this habitat include: spiders and insects; reptiles such as the Gulf salt marsh snake (Nerodia fasciata clarki) and American alligator (Alligator mississippiensis); birds such as the green heron (Butorides striatus) and clapper rail (Rallus longirostris); and mammals including the swamp rabbit (Sylvilagus aquaticus) and northern raccoon (Procyon lotor).

\section{d. Brackish/Intermediate Marsh}

The boundary line, or transition zone, between brackish marsh and intermediate marsh is less distinct than for other wetland habitats. Floral and faunal assemblages, of ten considered to be characteristic of either brackish or intermediate marsh, tend to overlap. For this reason, and because of the overall similarity of these two habitat types, they will be discussed here under one category.

The brackish/intermediate marsh is the most extensive wetland habitat type of the Gulf Coast. These marshes tend to form broad vegetative bands 
paralleling the coastline and main distributary channels. The tidal flushing frequency in this habitat is less than for salt marsh while the effects of freshwater inflows are more pronounced.

As with salt marsh, reported values for characteristic salinities tend to vary. Chabreck (1972) identified an average salinity for brackish marsh as $5.1 \mathrm{ppt}$ ranging upwards to $13 \mathrm{ppt}$. Other values reported in the literature include 5-18 ppt (Cowardin and others, 1979) and 8-18 ppt (Montz, 1977). The average salinities reported for intermediate marsh are somewhat lower at 0.5-5 ppt (Cowardin and others, 1979), 1-8 ppt (Montz, 1977), and 2.2-6 ppt (Chabreck, 1972).

Characteristic species of vegetation include the dominant salt meadow cordgrass or wiregrass (Spartina patens), saltgrass (Distichlis spicata), Olney's three-corner grass (Scirpus olneyi), and seashore paspalum (Paspalum vaginatum). As Gosselink and others (1979) have noted, species diversity tends to be higher in this marsh type, probably due to the occurrence of opportunists such as bulltongue (Saggittaria falcata) and common reed (Phragmites communis) which are normally considered fresh marsh species. The brackish/intermediate marsh is the most productive of all marsh habitats (Craig and Day, 1977) with primary productivity estimated at $2,800 \mathrm{~g} / \mathrm{m}^{2} / \mathrm{yr}$ (Gosselink and others, 1979).

Typical wildlife species include: numerous species of invertebrates; reptiles such as the diamond back terrapin (Malaclemys terrapin); birds, primarily as migrants, including the great blue heron (Ardea herodias), northern pintail (Anas acuta), and white ibis (Eudocimus albus); and several species of mammals including the common muskrat (Ondatra zibethicus), white-tailed deer (Odocoileus virginianus), northern raccoon (Procyon lotor), and the endangered red wolf (Canis rufus).

\section{e. Ridge}

For the purposes of the present study, the ridge habitat category includes: chenier ridges, beach ridges, and natural and man-made levees. The natural ridges of the chenier system of southwestern Louisiana and the coastal Texas barrier-strandplain system are, in general, confined to areas proximal to the coastline, occurring less frequently further inland. In contrast, man-made ridges 
consisting of spoil banks and levees are more numerous in inland areas, occurring along distributary channels and water courses and forming perimeters of marsh impoundments.

Floristic composition, typical of the coastal ridge habitat, include bluestem (Andropogen littoralis), sea oats (Uniola paniculata), gulf-dune paspalum (Paspalum monostachyum), and coastal sand bur (Cenchrus incertus). Inland ridges, generally above tidal influence, support vegetation such as live oak (Quercus virginiana), salt cedar (Tamarix gallica), and button bush (Cephalanthus occidentalis).

As with vegetation, faunal assemblages vary greatly depending on the type of ridge (levee, spoils bank, chenier, etc.) and the influencing hydrologic regime. Characteristic species include reptiles such as the ground skink (Leilopisma laterale) and racer (Coluber constrictor); and mammals such as the short-tailed shrew (Blarina brevicauda), fox squirrel (Sciurus niger), eastern harvest mouse (Reithrodontomys bumulis) and white-tailed deer (Odocoileus virginianus). Ridge systems also provide roosting and nesting sites for numerous species of birds including the olivaceous cormorant (Phalacrocorax olivacieous), glossy ibis (Plegadis falcinellus), Cooper's hawk (Accipter cooperi), and red-winged blackbird (Agelaius phoeniceus).

\section{f. Inland Open Water}

The inland open water habitat includes inland bayous, canals, rivers, ponds, and lakes, as well as the semi-enclosed bays and estuaries of coastal Texas. Salinities within these bodies of water vary as a function of hydrologic regime and proximity and access to Gulf waters. The bays, estuaries, and lagoons of Texas are relatively low-energy environments protected by barrier islands and peninsulas. These estuarine systems are generally shallow and well-mixed. Coastal lakes and ponds located adjacent to bay margins vary in depth from a few centimeters to a few meters.

Because of the high diversity of available habitat features, the vegetation and wildlife diversities are correspondingly high. Aquatic vegetation includes phytoplankton and benthic algae. Invertebrate species are numerous, representing 
most taxa. In the portions of Texas estuaries where the salinity range is from 8-15 ppt, the brackish water clam, Rangia cuneata, is the dominant benthic invertebrate.

The fresher water bodies support amphibians as well as reptiles including the diamond back water snake (Nerodia rhombifera). Fishes characteristic of these inland waters include spotted gar (Lepisosteus oculatus), speckled worm eel (Myrophis punctatus), ribbon shiner (Notropis fumeus), and blue catfish (Ictalurus furcatus). Birds utilizing these habitats include wood ibis (Mycteria americana), northern shoveler (Anas clypeata), gadwall (Anas strepera), and mottled duck (Anas fulvigula).

\section{g. Fresh Marsh}

Fresh marsh provides a major habitat for migratory water fowl and occurs throughout much of the Gulf coastal zone. The hydrologic regime is dominated by freshwater inflows, precipitation, and shallow groundwater. Fresh marsh experiences a lower frequency of tidal inundation than does salt or brackish/intermediate marsh. As a result, detritus export is reduced and organic material tends to accumulate. Salinity values characteristic of this habitat have been estimated at: less than $0.5 \mathrm{ppt}$ (Cowardin and others, 1979) and 0-1 ppt (Montz, 1977).

Floral species diversity in fresh marsh is generally higher than for other marsh types. This may in part be accounted for by the presence of annuals which tend to form a less stable community complex (Gosselink and others, 1979). Submergent vegetation is dominated by fanwort (Cabomba carolina), coontail (Ceratophyllum demersum), and pondweed (Potamogeton spp.). Characteristic emergent species include maidencane (Panicum hemitomon), salt meadow cordgrass (Spartina patens), bulltongue (Saggitaria falcata), and alligator weed (Alternanthera philoxeroides). Gosselink and others (1979) have tentatively estimated primary productivity for fresh marsh to be approximately $2,200 \mathrm{~g} / \mathrm{m}^{2} / \mathrm{yr}$.

The invertebrate taxa are well represented in fresh marshes with insects assuming many of the functional roles that crustaceans occupy in the more saline habitats (Gosselink and others, 1979). Amphibian and reptile diversities are 
higher in fresh marsh than in other marsh types. Representative amphibians include the Gulf Coast toad (Bufo valliceps) and the marbled salamander (Ambystoma opacum). Reptiles include the American alligator (Alligator mississippiensus). Bird species diversity is comparable to that of other marsh types. Characteristic species are the yellow-crowned night heron (Nyctanassa violacea), little blue heron (Florida caerulea), and the least bittern (Ixobrychus exilis). Mammalian species are similar to those of the brackish/intermediate marsh. Nutria (Myocaster coypus) is the most abundant large herbivore and a commercially important fur species. Other mammals include northern raccoon (Procyon lotor) and coyote (Canis latrans).

\section{h. Swamp Forest}

These forested freshwater wetlands are typically located in the upper floodplains of major river systems beyond the influence of brackish waters. Soils of this habitat are generally saturated or submerged a minimum of one month per year. Swamp forests are functionally similar to marshes; however, woody vegetation and elevational differences contribute to a spatial heterogeneity not found in marshes (Gosselink and others, 1979).

A high floral species diversity is associated with the spatial heterogeneity and varying soil moisture of the swamp forest. Characteristic vegetation includes water tupelo (Nyssa aquatica), water oak (Quercus nigra), baldcypress (Taxodium distichum), and wax myrtle (Myrica cerifera). Primary productivity is estimated by Conner and Day (1976) at $1140-1574 \mathrm{~g} / \mathrm{m}^{2} \mathrm{yr}$.

Amphibians and reptiles, well-represented in the swamp forest, include such species as the squirrel tree frog (Hyla squirella), snapping turtle (Chelydra serpentina), Texas rat snake (Elaphe obsoleta lindheimeri), and western cottonmouth (Agkistrodon piscivorus). Representative birds include the greater horned owl (Bubo virginianus), pileated woodpecker (Dryocopus pileatus), and brown thrasher (Taxostoma refum). Mammalian species that inhabit swamp forest include the Virginia opossum (Didelphis virginiana), North American mink (Mustela vision), seminole bat (Lasiurus borealis), and bobcat (Lynx rufus). 


\section{i. $\quad$ Agriculture}

This habitat classification includes rice fields, pasture/grazing land, and other domestic cropland. These areas are discussed here only within the context of habitat provided for wildlife.

In general, the conversion of natural habitats to agricultural lands results in a reduction of available wildlife habitat. However, certain species can benefit from the conversion if an exploitable habitat is enlarged or created. This is particularly true for waterfowl. Pasture lands provide habitat for a number of different taxa. Amphibians such as the central newt (Notophthalmus viridescens) and bullfrog (Rana catesbeiana) utilize the numerous ponds that form in low areas whereas reptiles including the ornate box turtle (Terrapene ornata) and the prairie kingsnake (Lampropeltis $\underline{\text { calligaster }}$ calligaster) inhabit dryer areas. Birds representative of this habitat include the Canada goose (Branta canadensis), cattle egret (Bubulcus ibis), common crow (Corvus brachyrynchos), and house sparrow (Passer domesticus). Several species of mammals that utilize these areas include the striped skunk (Mephitis mephitis), coyote (Canis latrans), and the endangered red wolf (Canis rufus).

The conversion of prairie or fresh marsh to rice fields has been widespread in the Gulf coastal region. Some species have benefited from this conversion. Gosselink and others (1979) report that the amphibian species diversity of rice fields is exceeded only in the swamp forest habitat where arboreal niches are available. Representative amphibians and reptiles include the upland chorus frog (Pseudacris triseriata), eastern narrow-mouthed toad (Gastrophryne carolinensis), glossy crayfish snake (Regina grahamii), and Mississippi mud turtle (Kinosternon subrubrum).

During fall, winter, and spring, when they are partially flooded, rice fields provide habitat for numerous species of waterfowl including the Canada goose (Branta canadensis), snow goose (Chen caerulescens), and king rail (Rallus elegans). In summer, rice fields provide nesting habitat for the mottled duck (Anas fulvigula) and the common gallinule (Gallinula chloropus). Opportunistic species such as the house sparrow (Passer domesticus), red-winged blackbird (Agelaius phoeniceus), and the European starling (Sturnus vulgaris) feed on waste grain 
(Gosselink and others, 1979). Mammalian species that utilize rice fields are similar to those of the pasture and fresh marsh habitats.

\section{j. Upland}

The upland habitat classification includes prairie grasslands and upland forests and woodlands. Coastal prairies are generally located between coastal marshes and upland forests and consist of a mixture of short, medium, and tall grasses. Snyder and others $(1978$, p. 17) have described the coastal prairies as: "a fire disclimax ecosystem; a subclimax seral stage maintained through time by the periodic disruptive forces of fire." Without periodic fires, the grasslands would gradually evolve into woody brushland. In contrast, forest or woodland habitat is characterized by a high biomass of standing vegetation and surface litter. The upland hydrologic regime is dominated by precipitation and ephemeral surface drainage.

The floristic composition of the coastal prairie is characterized by bluestem (Andropogen spp.) and indiangrass (Sorghastrum spp.). The primary producers associated with upland forests are typified by pecan (Carya illinoensis), live oak (Quercus virginiana), and loblolly pine (Pinus taeda).

Consumers of the coastal prairie typically include insects; reptiles, such as the prairie kingsnake (Lampropeltis calligaster calligaster); rodents, such as the cotton rat (Sigmodon hispidus); birds, including the meadow lark (Sturnella magna), the endangered Attwater prairie chicken (Tympanuchus cupida attwateri), redshouldered hawk (Buteo lineatus), and turkey vulture (Cathartes aura); and mammals including the coyote (Canis latrans).

Consumers in upland forests and woodlands consist of insects and amphibians including the northern cricket frog (Acris crepitans) and Woodhouse's toad (Bufo woodhousei). The blue jay (Cyanocitta cristata), Carolina wren (Thryothorus ludovicianus), red-headed woodpecker (Melanerpes carolinus) and the common screech owl (Otus asio) are representative of the upland avifauna. Typical mammalian species of the upland forest include the gray squirrel (Sciurus carolinensis), eastern mole (Scalopus aquaticus), red bat (Lasiurus borealis), and northern raccoon (Procyon lotor). 


\section{Subsidence and Ecosystem Dynamics}

This section provides a brief overview of the critical components comprising a "typical" ecosystem and illustrates the extreme complexity of the system linkages. A discussion of the interrelationships between subsidence phenomena and ecosystem dysfunction at the biological assemblage level is also presented. To attempt to achieve a comprehensive assessment of the effects of subsidence on the local ecosystem as a whole would be somewhat presumptuous. However, even though the complexity of the problem is extreme, general cause-and-effect linkages can be identified, and reasonable estimates of the consequences or effects can be made.

Table IV-1 provides the definitions for the energy-mass flow symbols used in the system diagrams accompanying this section.

In general, there are four major components that comprise a given habitat or system. These component categories include:

Energy and materials sources and storage. This category includes light energy necessary for photosynthetic activity; mechanical energy in the form of tidal flow, wind, and other active processes; and basic chemical constituents such as oxygen, carbon dioxide, nitrate, ammonia, and phosphate. Material and energy storage can include water, organic detritus, and sediment.

Producers. These are the autotrophic organisms including most plants and some bacteria that are able to synthesize organic molecules from inorganic substances.

Consumers. These are the heterotrophic organisms that are unable to manufacture organic compounds and; thus, must feed on autotrophs (producers) and other heterotrophs (lower-order consumers).

Decomposers. This category includes the micro-organisms such as bacteria and fungi that are responsible for the conversion of dead organic material into basic plant (producer) nutrients. 
Table IV-1 Energy/Mass Flow Symbols and Their Definitions

SYMBOL

DESCRIP'TION

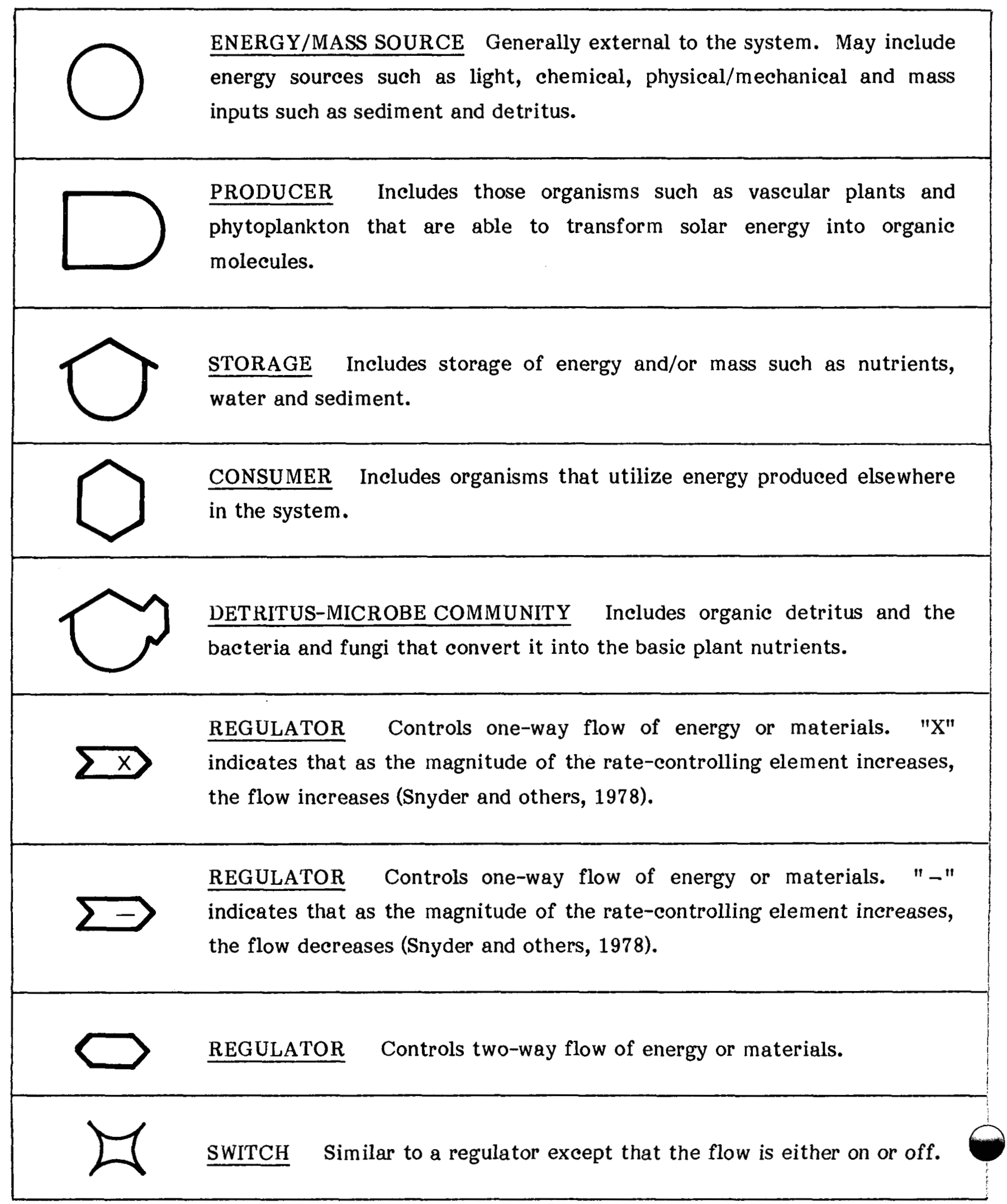


These system components are intricately linked through numerous and complex physical, chemical, and biological processes. In turn, each habitat or subsystem is linked through these same processes to the other subsystems or habitats that comprise the regional ecosystem (Figure IV-6).

The complexities of the energy-mass flows in an ecosystem can be illustrated in a systems diagram of a Gulf coastal brackish marsh (Figure IV-7). This diagram is modified after that of Snyder and others (1978). Additional references for coastal ecosystem energy flow diagrams are presented in Table IV-2.

The utility of a system diagram becomes readily apparent when attempting to trace the cause-and-effect linkages between subsidence phenomena and ecosystem response. As discussed previously (Section IV.B.), primary subsidence impacts tend to focus on the geohydrologic regimes. These impacts include: alteration of streamflows and drainage patterns; localized inundation including ponding and lake formation or enlargement; increased exposure to tidal inundation; and the associated effects of erosion and sedimentation. Alteration of the existing hydrologic regime necessarily results in a change in the adapted vegetation and faunal assemblages. Alterations can occur as loss resulting from submergence or loss resulting from diversion of a water supply.

Subsidence-ecosystem linkages are less complex in upland areas than in wetland areas. In upland areas the primary concerns are alteration of surface water flows (and associated floodplains), potential water impoundment, and enlargement of existing ponds or lakes. The effects of subsidence phenomena on wetland ecosystems are considerably more complex.

Diversion of freshwater inflows to swamp forest habitat results in the reduction of frequency and/or duration of inundation as well as the increase of water salinity from increased saltwater intrusion. Either situation can result in a change or loss of existing vegetation and faunal communities. For example, West (in press) has indicated that a salinity increase of $10-20 \mathrm{ppt}$ will result in the deterioration of baldcypress (Taxodium distichum). Alternatively, reduced drainage from the swamp forest system could result in water impoundment, water logging of soils, and reduced nutrient flux. Sklar and Conner (1979) observed a significant reduction in hardwood production, leaf litter, and aquatic invertebrate 


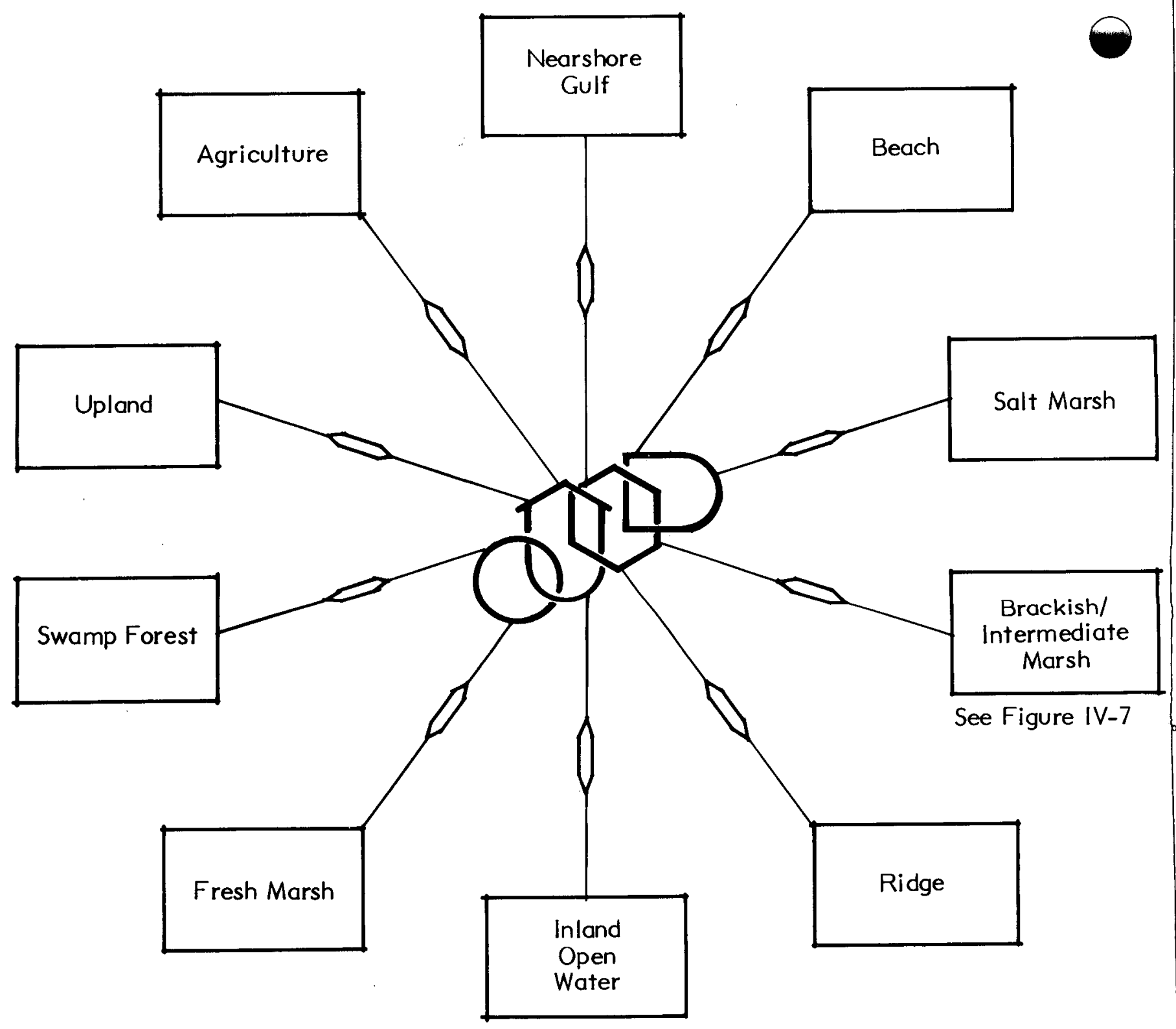

Figure IV.6 Conceptual Habitat Linkage for the Gulf Coast Ecosystem 


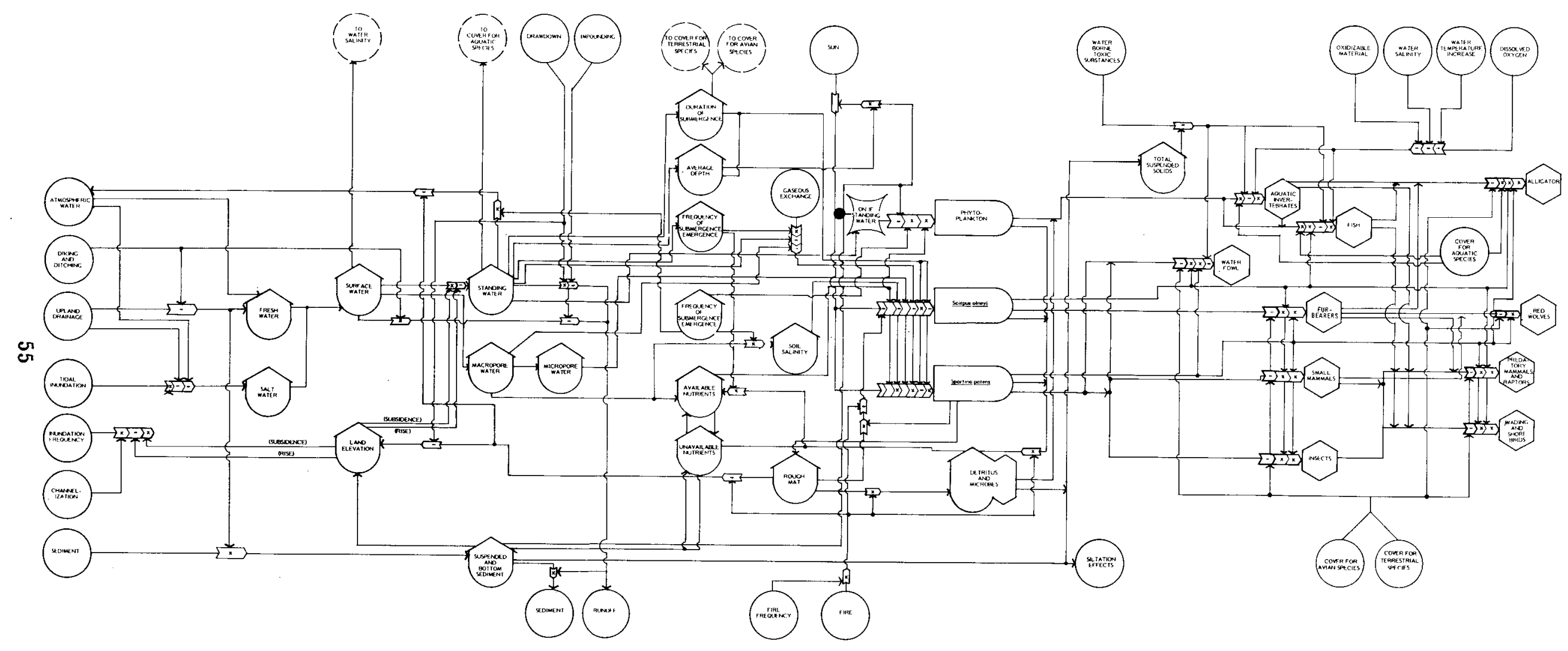


Table IV-2 Partial Listing of References for Coastal Ecosystem Energy/Mass Flow Diagrams

\section{REFERENCE}

Bahr and others, 1977

Clark, 1974

Cronin, 1975

Cross and Williams, 1981

Day and others, 1973

Earle, 1972

Gosselink and others, 1979

Green, 1968

Odum and others, 1977

Proctor and others, 1980

Snyder and others, 1978

T.D.W.R., 1979a

T.W.D.B., 1974

T.W.D.B., 1977
HABITAT CODE

$c, e, s, t, x, y$

i

q

i

c, i

c, i

c, e, i, o, p, v, $\mathrm{w}, \mathrm{x}, \mathrm{y}$

i

h, k

a, d, f, l, o

$\mathrm{h}, \mathrm{m}, \mathrm{n}, \mathrm{g}, \mathrm{r}, \mathrm{u}$

i

b, e
HABITAT CODE DESCRIPTION

a. General Ecosystem

b. Terrestrial

c. Wetland

d. Emergent Vegetation

e. Aquatic

f. Euphotic Pelagic Oceanic

g. Nearshore Gulf

h. Bay

i. Estuary

j. Inland Open Water

k. Oyster Reef

1. Eelgrass

m. Wind Tidal Flats

n. Tidal Stream Reach

o. Beach

p. Ridge

q. Salt Marsh

r. Brackish Marsh

s. Managed Marsh

t. Coastal Basin

u. Coastal Prairie

v. Upland Forest

w. Agriculture

x. Pasture

y. Rice Field 
species diversity in an impounded area of the Louisiana Lac des Allemands swamp forest ecosystem.

In brackish marshes, a reduction of freshwater inflows can result in increased salinities from inland intruding Gulf waters. This leads to the replacement of existing emergent vegetation such as salt meadow cordgrass (Spartina patens) and Olney's three-corner grass (Scirpus olneyi) with the more salt tolerant species such as smooth cordgrass (Spartina alterniflora) and saltgrass (Distichlis spicata). Associated with this change in floristic composition is the change in the locally adapted faunal assemblages.

The reduction or loss of sediment inflows can have similar effects. In those areas where aggradation cannot keep pace with subsidence; ponding, inundation, and erosion caused by increased wave fetch can occur and result in a complete loss of vegetation and displacement of wildlife in the affected area. The highly organic soils of the brackish marsh are particularly susceptible to erosive forces, more so than the more inorganic soils of the salt marsh habitat. Loss of the brackish marsh buffer poses an even greater threat to the adjacent and more fragile fresh marsh habitat.

Similar effects can occur as a direct result of vertical settlement and surface tilt. If a marsh area is drained, subsequent oxidation and shrinkage of the highly organic soils will result in land surface settlement below the mean water level (Gagliano and van Beek, 1970), eventually resulting in permament submergence and loss of marsh habitat. Thus, as the marsh system deteriorates, the hydrologic regime changes, resulting in a further deterioration or alteration of the marsh essentially creating what Craig and others (1979) refer to as a "positive feedback loop with no control".

The deterioration or alteration of the marsh habitat in terms of reduced plant cover and food resources not only reduces the carrying capacity for resident aquatic invertebrates, fish, waterfowl, and fur bearers, but detrimentally affects adjacent habitats and systems as well. The net loss of marsh land ultimately results in a net reduction in detritus production and subsequent export (including the associated micro-organisms) from the marsh to the adjacent estuarine system. The detrital complex serves as a primary energy/food source for the ubiquitous 
lower-order estuarine consumers including amphipods, isopods, mysid shrimp, small crabs, insect larvae, caridean shrimp, and certain fishes (Odum, 1970). A reduction in the detritus pulse or export from the marsh lowers the available food resources for this consumer group, effectively decreasing the standing crop with commensurate effects on subsequently higher trophic levels. As Odum points out, because of the relative simplicity and shortness of estuarine trophic linkages, and the general dependence upon a few key organisms that utilize the detritus-microbe complex, these estuarine systems are particularly vulnerable to disruption of the system linkages.

A reduction in overall inland marsh acreage can also alter the hydrologic regime in terms of an increased tidal flux in the bay-estuary-tidal stream reach system, resulting in increased rates of erosion of barrier islands at the tidal passes (West, in press). Deterioration of barrier islands leads to reduced buffering and protection from tidal and storm forces and a subsequent increase in beach and coastline erosion, again producing an uncontrolled feedback loop. Loss of beach and coastline can also occur as a direct result of vertical settlement and inundation, as well as from insufficient sediment outflow to counter erosive Gulf coastal processes.

Thus, the effects of subsidence on an ecosystem, regardless of size, are numerous and extremely complex. The perceived effects or ecosystem alterations will most surely be the result of several factors. It is readily apparent, however, that the relatively fragile coastal wetland habitats are significantly more vulnerable to the effects of subsidence phenomena than the less sensitive upland habitats.

\section{Capability of Ecosystems to Adapt to Subsidence}

A thorough analysis of subsidence effects on Gulf Coast ecosystems requires the consideration of ecosystem resiliency or ability to adapt to a changing environment. This resiliency is dependent, to an extent, upon the existing fitness of the system or system component (organism) and on the magnitude of the perturbation or effect to which the system must respond. In some cases, the magnitude or character of the effect can be so severe that recovery or adaptation is not possible. In other circumstances, the effect may be so slight as to elicit no system response at all. 
A major obstacle in attempting such an analysis is the inherent complexity of the ecosystem linkages. The response of a particular organism to a base change in its environment is likely to be a response to multiple manifestations of that change. For example, in the coastal marshes of Louisiana, the response of muskrat (Ondatra zibethicus) to subsidence and land loss would likely be a function of altered or reduced forage vegetation, loss of cover, and, if displaced into fresher marsh areas, increased competition with nutria (Myocastor coypus). Thus, an evaluation of system resiliency must necessarily be an analysis of the cumulative responses to specific environmental parameters.

\section{a. Geologic Resiliency}

In general, the resiliency of the lithosphere to subsidence phenomena is minimal at best. Subsidence-related ground movements are for all practical purposes irreversible, subject only to alteration by other geomorphic processes. Vertical settlement of land is the most conspicuous manifestation of subsidence and is the focus of this discussion.

Vertical settlement associated with geopressured geothermal subsidence will predominantly occur as a result of compaction of fine-grained deep sediments and, in some cases, compaction of surficial organic soils. Compaction of fine-grained deep sediments can be caused by a reduction in hydrostatic and intergranular pressure caused by fluid withdrawal. Because of the relative inelasticities of deep sediments (particularly the clayey sediments) these compaction processes and associated surficial settlements can be considered permanent.

Subsidence-induced alteration or diversion of surface and/or subsurface drainages can result in the dewatering and subsequent compaction of wetland organic soils. Todd (1980) lists several causes of organic soil compaction as a result of dewatering including: shrinkages caused by dessication, consolidation by loss of the bouyant force of groundwater, wind erosion, and biochemical oxidation. These factors can contribute significantly to vertical land subsidence when wetland soils are dewatered. When this occurs, the habitat associated with the affected area is generally irreversibly altered. Although some soils can be partially rehydrated and a certain amount of buoyancy can be restored, wind erosion and 
biochemical oxidation result in permanent localized changes. If compaction occurs in coastal marshes, the potential for permanent land or habitat loss is significantly increased. In these areas, soil compaction and subsidence below tidal levels can result in permanent inundation.

\section{b. Biologic Resiliency.}

Flora. Potential biologic resiliency can be characterized by the ability of individual species to adapt to variation and change in specific environmental parameters. The two principal parameters that are of concern, in the context of Gulf coastal floristic composition, are inundation and salinity.

In most soil-plant systems, soil water that is usable by a plant is that which is held at a tension of less than 15 atmospheres of pressure with soil water content at field capacity (Clapham, 1973). Field capacity can be defined as "the amount of water that can be retained in a soil by capillary attraction when it is free to percolate under the influence of gravity" (Clapham, 1973). Soil water content in excess of field capacity begins to fill air spaces, reducing soil oxygen content and availability to plant roots. Air spaces can become completely filled with water when soil water content reaches maximum retentive capacity or saturation. When the root systems of non-emergent plants are submerged for an extended period of time as a result of inundation, they are not able to obtain the oxygen they need and the vegetation will die back, leaving open water. As discussed previously (Section IV.C.2), Sklar and Conner (1979) observed a reduction in hardwood production in an impounded portion of a Louisiana swamp forest. Several other researchers have identified the waterlogging of soils and subsequent oxygen depletion in root systems as likely contributing factors in localized Spartina spp. diebacks (Miller and Egler, 1950; Chapman, 1960; Smith, 1970.)

The duration and frequency of tidal inundation are significant factors contributing to floristic distribution in coastal marsh ecosystems (Daigh and others, 1938; Penfound and Hathaway, 1938; Chapman, 1940; Cottam and Bourn, 1952; Adams, 1963; Seneca, 1969; Smith, 1970; Daiber, 1974; Lagna, 1975; Eleuterius and Eleuterius, 1979; Ward and Armstrong, 1979). The exposure of the marsh habitat to these factors is determined primarily by the elevation of the marsh relative to a specific tidal level such as mean sea level. Cottam and others 
(1938) reported that floral distribution in the marsh community could be influenced by a 3 centimeter $(\mathrm{cm})$ change in water level, while Penfound and Hathaway (1938) indicated that an elevational change of less then $8 \mathrm{~cm}$ could affect floristic composition. For a Spartina alterniflora salt marsh in Davis Bay, Mississippi, Eleuterius and Eleuterius (1979) identified the elevational range for $\underline{\mathbf{S}}$. alterniflora as $24 \mathrm{~cm}$ below mean low water (MLW) to $54 \mathrm{~cm}$ above MLW. A Juncus roemarianus zone ranging from $54 \mathrm{~cm}$ above MLW to $75 \mathrm{~cm}$ above MLW was also determined. Their analysis indicated that the frequency of inundation in $\mathbf{1 9 7 5}$ for the $\underline{\mathrm{S}}$. alterniflora zone was 139 times compared to 16 times for the $\underline{\mathrm{J}}$. roemarianus zone. In a study of the marshes of the Lake Ponchartrain, Barataria, and Terrebonne drainage basins in coastal Louisiana, Sasser (1977) reported an elevational range for the marsh community as approximately $9 \mathrm{~cm}$ below mean sea level (MSL) to $9 \mathrm{~cm}$ above MSL.

In addition to the citations above, there is an extensive body of literature addressing the effects of salinity on coastal wetland vegetation (Webb, 1965; McMillan and Mosely, 1967; Mayer and Low, 1970; Hopkins, 1973; Ward and Armstrong, 1979). In their report on the effects of freshwater inflows to Matagorda Bay, Texas, Ward and Armstrong (1979) have identified from the literature the salinity tolerance limits and optimal ranges for several of the dominant and common floral species of Gulf coastal marshes. Hopkins (1973) has assembled an extensive annotated bibliography on effects of salinity and salinity change on the coastal estuarine environment.

Most species of marsh plants are facultative halophytes achieving higher rates of productivity and greater seed viability the lower the salinity of the influencing hydrologic regime. The ability of halophytes to survive and flourish in a relatively harsh saline environment has necessitated the adaptation to several obstacles. Queen (1974, p. 206) has identified three major obstacles: ". . a acquisition of water from an external solution with a high osmotic pressure; maintenance of internal ionic balance within narrow limits; and absorption of sufficient essential nutrients from a medium with an ionic mix unfavorable to higher plants." In a study of greenhouse cultures of smooth cordgrass (Spartina alterniflora) and salt meadow cordgrass (Spartina patens), Gosselink (1970) reported that both species had to expend energy to accumulate chlorine and exclude sodium when exposed to salinities of 10-20 ppt. 
Even with the special adaptive features necessary to surmount such obstacles, when salinity levels exceed maximum tolerance limits, marsh vegetation begins to deteriorate and floristic composition is altered. Ward and Armstrong (1979) have described such a scenario, which is summarized here, for the marshes of the Matagorda Bay area of coastal Texas. In general, optimum productivity for Spartina alterniflora is achieved at a salinity of approximately 5 ppt. An increase in salinity above the optimal level could result in a reduction of productivity. Accompanying the increase in salinity would be the gradual encroachment of $\underline{S}$. alterniflora into adjacent brackish/intermediate marsh currently supporting floral species which are less salt tolerant than $\underline{S}$. alterniflora. This could potentially result in an overall increase in the standing crop of $\underline{S}$. alterniflora in the Matagorda Bay area at the expense of species diversity. Similarly, salinities could increase to the upper limit of the optimum productivity range for Spartina patens or even higher, resulting in a reduced level of

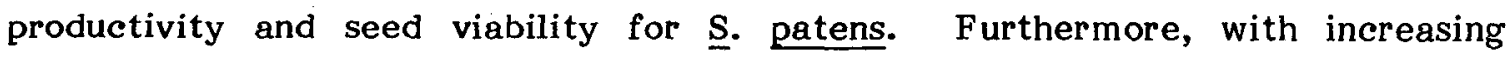
salinities $\underline{S}$. patens may migrate inland invading traditionally fresher areas and displacing less salt tolerant species.

It should be noted, however, that the perception of coastal marshes simply migrating inland as a result of land subsidence is a deceptive one. There is necessarily an inland boundary limitation (usually a function of elevation and tidal regime) restricting marsh migration. Thus, there is generally a net loss of actual marsh area, which in Gulf coastal areas is most frequently brackish/intermediate marsh. At a minimum, there is a conversion of high productivity marsh to a less productive marsh or open water habitat.

In addition to coastal marshes, there are other ecosystems that are influenced by the salinity regime. In their evaluation of the effects of increasing salinity on the dominant vegetation of Texas coastal estuaries, McMillan and Mosely (1967) reported the following findings. Of four dominant species, Thalassia testudinum, Diplanthera wrightii, Ruppia maritima, and Syringodium filiforme, $D$. wrightii demonstrated the greatest tolerance to increasing salinity while lower salinity tolerances were demonstrated by $\underline{T}$. testudinum and $\underline{R}$. maritima. S. filiforme exhibited the lowest tolerance to increasing salinity. The floristic composition and zonation of beach ridges has also been shown to be strongly influenced by salinity, particularly in the form of salt spray (Boyce, 1954). 
Thus, it is apparent that the intrusion of higher salinity Gulf waters into coastal ecosystems, particularly wetland habitats, can have severe and frequently insidious effects on the floristic composition of these habitats. This intrusion can result from vertical settlement of wetland soils or from reduced freshwater outflow. In the first case, habitat alterations are generally permanent. In the second case, the degree of vegetation resiliency to the resulting change in salinity will depend on the term or duration of reduced flows. If freshwater flows are restored, vegetation will likely achieve a level of recovery commensurate with the degree of restoration of the previous hydrologic regime. However, if freshwater inflows are permanently diverted or sufficiently reduced, sediment transport and wetland aggradation will not be able to keep pace with natural subsidence and permanent wetland loss will occur as a result of tidal inundation.

Fauna. Faunal response to environmental change is more subtle, yet more complex. Subsidence phenomena are relatively slow processes, of ten occurring at rates of millimeters per year in the Gulf Coast. The perceived effect is one of gradual displacement of the faunal composition usually over a period of several years. This process, though slow in human perception, is extremely rapid in evolutionary terms.

For most species, an optimal environment or habitat can be identified as well as a range of tolerance limits for specific, critical environmental parameters. When these limits are approached or exceeded, the organism becomes environmentally stressed. There is an extensive body of literature describing some of the critical environmental parameters and tolerance limits for many of the major faunal species of Gulf coastal ecosystems (Zine-Eldin, 1963; Gunter and others, 1964; Parker, 1970; Adkins, 1972; Dunham, 1972; Day and others, 1973; Gaidry and White, 1973; Hopkins, 1973; Hopkins, 1973; Gosselink and Hebrard, 1977; Parker, 1955; Van Sickle and others, 1976; Gosselink and others, 1979; Texas Department of Water Resources, 1979b; Ward and Armstrong, 1979). Subsidence phenomena, acting through these critical environmental parameters, can affect an organism either directly (the exposure of aquatic species to increasing levels of salinity) or indirectly (reduced cover or increased competition).

Regardless of whether the manifestation of the impact is direct, indirect, or a combination of both, if the stress is severe enough the population can 
be reduced to a critical minimum size below which recovery is unlikely. Thus, faunal resiliency to subsidence phenomena will be determined by the magnitude and rate of environmental change, the characteristics of that change and the existing health or fitness of the target species of population. 


\section{GEOPRESSURED GEOTHERMAL-RELATED SUBSIDENCE: POTENTIAL IMPACTS AND SIGNIFICANCE}

An evaluation of the impacts associated with geopressured geothermal resource development must necessarily take into consideration the existing conditions of the area under study. As discussed elsewhere in this report, the Texas-Louisiana Gulf Coast is currently experiencing varying rates of both maninduced and natural land subsidence. As a result, the Gulf Coast is a dynamic environment undergoing continuous changes in geomorphology and habitat. These changes are particularly evident in the near-sea-level coastal marshlands, where the flora and fauna are in a state of constant change as they adapt or fail to adapt to natural changes. The natural and man-induced rates of subsidence have been combined in the present analysis in order to provide a rate comparison between total background subsidence and projected geopressured geothermal-related subsidence. Therefore, in the following discussion, potential geopressured-related subsidence impacts (in terms of disruption of ecosystem dynamics or linkages and alteration of current land uses) are evaluated in terms of the potential incremental change or acceleration of impacts caused by background subsidence.

\section{A. Cuero Prospect}

The habitat map presented in Figure V-1 represents a composite summary of information from the following sources: Draft Environmental Analysis of Geopressured Geothermal Prospect Areas in Colorado and DeWitt Counties, Texas (Bureau of Economic Geology, 1980); Land Resources of Texas (Bureau of Economic Geology, 1977); Cuero Quadrangle (1960), Meyersville Quadrangle (1963), Yorktown East Quadrangle, (1963), and Blackwell Lake Quadrangle (1960), Topographic Maps, U.S. Geological Survey.

Cuero Prospect is located within DeWitt County, Texas. The study area is predominantly upland/agriculture habitat. (Note: As a method of convenience in mapping the Cuero habitat areas, upland-prairie grasslands and agriculturepasture/rangeland were combined into one category -- upland/agriculture). Other habitat types within the area include inland open water, upland-woodland, and swamp forest. 


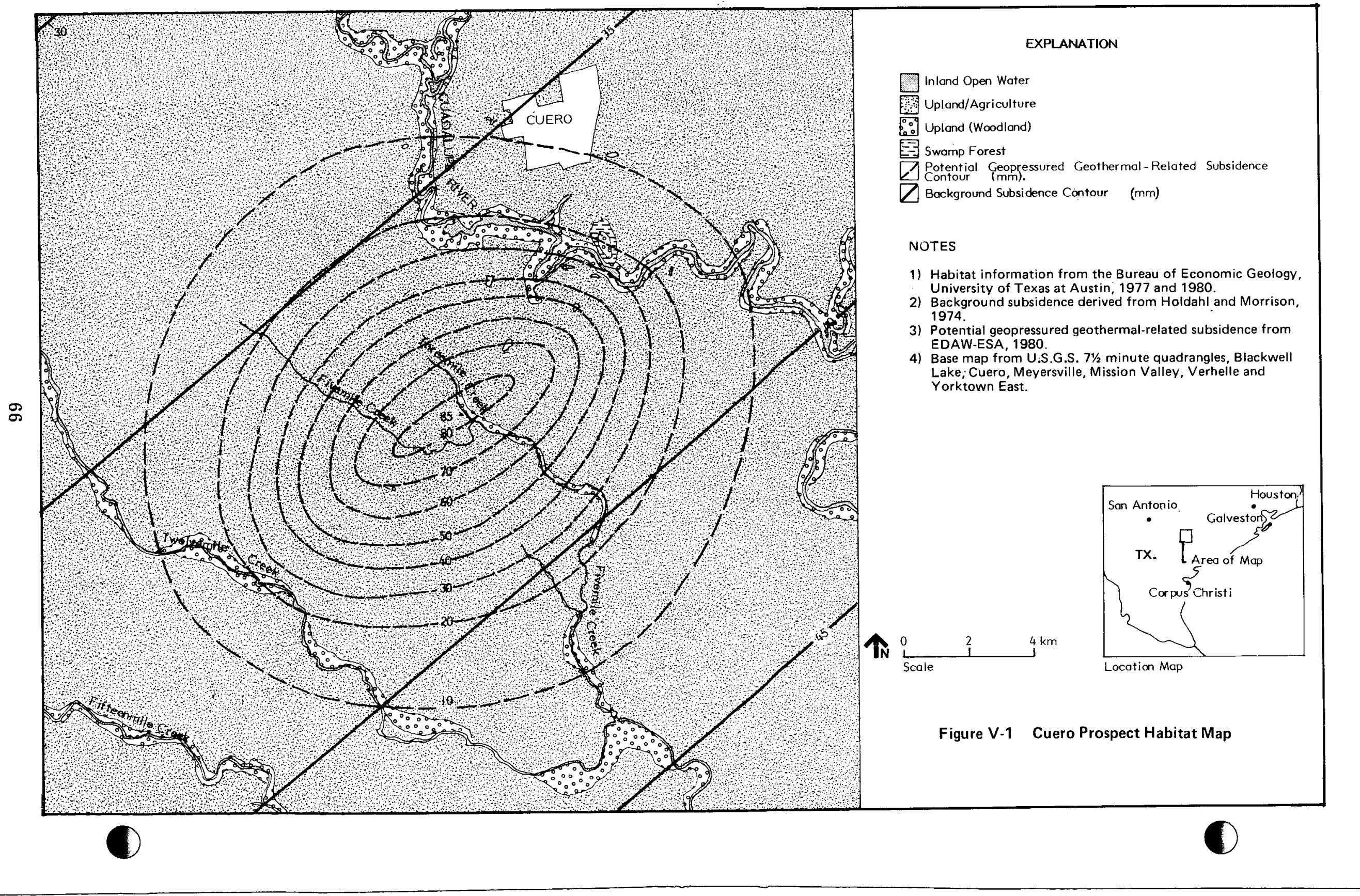


Local topography is primarily characterized by low rolling hills (upland/agriculture) ranging in elevation from 35 meters $(\mathrm{m})$ to $110 \mathrm{~m}$ but commonly less than $90 \mathrm{~m}$. Lower areas (inland open water, upland-woodland, and swamp forest) range in elevation from $35 \mathrm{~m}$ to $55 \mathrm{~m}$. The surface hydrologic regime is dominated by the northwest-southeast oriented creeks (Threemile, Fivemile, Twelvemile, and Fifteenmile) and the Guadalupe River. Flows in these watercourses are to the southeast. Surface watersheds and tributaries in the southern half of the study area drain to the east and southeast, primarily into Threemile, Fivemile, and Twelvemile Creeks. Surface drainage in the northern half of the study area is primarily to the north and northeast into the Guadalupe River. The projected subsidence bowl is over 24 kilometers in diameter and is centered just north of the confluence of Threemile and Fivemile Creeks. Projected geopressured geothermal -related subsidence rates range from 16 millimeters per year $(\mathrm{mm} / \mathrm{yr}$ ) for the first year of production to $0.3 \mathrm{~mm} / \mathrm{yr}$ for the last year (Table III-1). A background subsidence rate of $2 \mathrm{~mm} / \mathrm{yr}$ is projected over the life of production. Total projected geopressured geothermal subsidence over the estimated 20-year lifetime of the well is low, the potential maximum being $85 \mathrm{~mm}$ in the center of the bowl (Figure $\mathrm{V}-1$ ). Total background subsidence within the area of the bowl and over the same time period is projected to range from approximately 30 to $45 \mathrm{~mm}$.

The projected rate of geopressured geothermal-related subsidence is significantly higher than the background rate of subsidence during the initial years of production. However, these rates are not expected to cause significant acceleration of existing surficial processes or changes in the local predominantly upland/agriculture ecosystems. Furthermore, the projected total magnitude of subsidence is expected to have minimal impact. There might be very localized alteration of surface drainage and a potential increase in ponding at bowl center, but these alterations are expected to be insignificant in areal extent and magnitude. The minimal likelihood of any substantial alterations to the hydrologic regime of the study area indicates that no significant vegetation or wildlife impacts will occur from potential geopressured geothermal-related subsidence. 


\section{B. Pleasant Bayou Prospect}

The habitat map presented in Figure V-2 represents a composite summary of information from the following sources: Environmental Geologic Atlas of the Texas Coastal Zone, Galveston-Houston Area (Fisher and others, 1972); Land and Water Resources, Houston-Galveston Area Council (Bureau of Economic Geology, 1975); A Problem Definition Study of Subsidence Caused by Geopressured Geothermal Resource Development (EDAW-ESA, 1980); Mustang Bayou Quadrangle (1963), Hoskins Mound Quadrangle (1974), Topographic Maps, U.S. Geological Survey.

Pleasant Bayou Prospect is located within Brazoria County, Texas. The study area is predominantly upland/agriculture habitat composed of prairie grasslands, rangeland, and croplands. Other habitats found within the site include uplandwoodland (primarily adjacent to major watercourses), inland open water, fresh marsh, brackish/intermediate marsh, and salt marsh. As previously discussed (Section IV.C.1), the habitat classification system used in this report classifies the semi-enclosed bays and estuaries of Texas (such as Chocolate Bay and West Bay) as inland open water habitat. Local topography is of low relief, typical of the Texas coastal regions. Surface water flows are primarily to the south and southeast in major watercourses such as Chocolate and Austin Bayous.

The projected subsidence bowl is centered on Chocolate Bayou just east of Danbury and is over 21 kilometers in diameter. Projected geopressured geothermal-related subsidence rates range from $7 \mathrm{~mm} / \mathrm{yr}$ for the first year decreasing to $0.5 \mathrm{~mm} / \mathrm{yr}$ for the last year (Table III-1). The background subsidence rate is projected to be $6 \mathrm{~mm} / \mathrm{yr}$. Total projected geopressured geothermal subsidence over the 5.5-year estimated production life is a maximum of $16 \mathrm{~mm}$ at the bowl's center (Figure V-2). In comparison, background subsidence in the prospect area ranges from less than 15 up to about $100 \mathrm{~mm}$ for the same time period.

The low rates of projected geopressured geothermal-related subsidence relative to the projected rate of background subsidence are not expected to cause significant acceleration of existing surficial processes or changes in the local ecosystem. Furthermore, the potential impacts associated with the total magnitude of projected geopressured geothermal-related subsidence are 


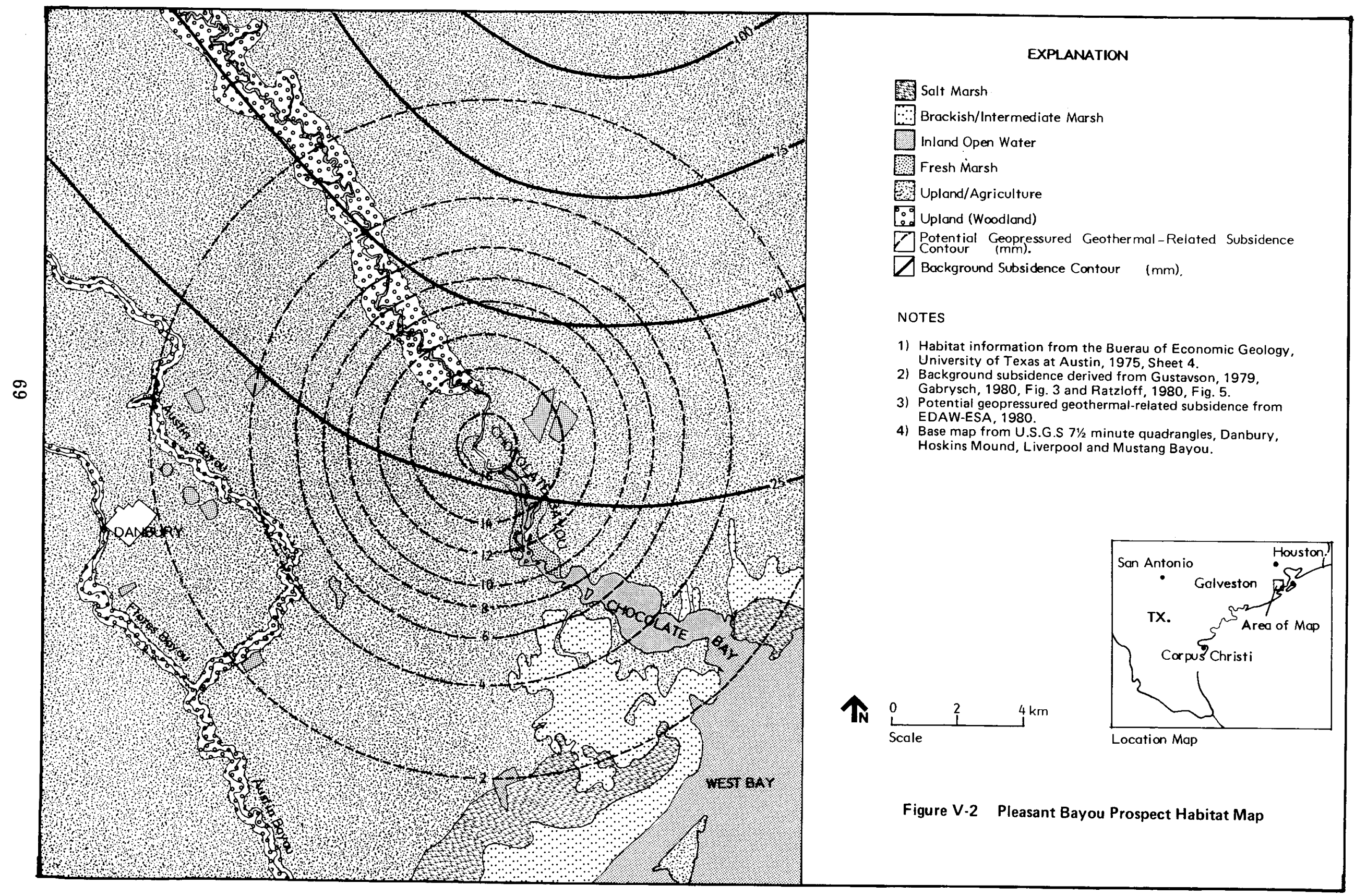


anticipated to be negligible. At the center of the bowl, sedimentation in Chocolate Bayou may increase slightly because of a marginal enlargement of the stream channel and reduction in flow gradient. However, this impact is foreseen as neglible. No impacts on local floodplains are expected. Within the coastal wetland habitats, the low projected total subsidence indicates that alteration of the existing tidal regime, specifically duration and frequency of tidal inundation, will not occur. Therefore, disruptive impacts upon the coastal wetland habitats are not expected.

Overall, due to the rates and magnitude of the geopressured geothermalrelated subsidence projected for the Pleasant Bayou Prospect study area, and the predominantly upland nature of the affected habitats, ecosystem impacts are expected to be insignificant.

\section{Gladys McCall Prospect}

The habitat map presented in Figure V-3 represents a composite summary of information from the following sources: Vegetative Type Map of the Louisiana Coastal Marshes (Chabreck and Linscombe, 1978); An Ecological Characterization Study of the Chenier Plain Coastal Ecosystem of Louisiana and Texas (Gosselink and others, 1979); Grand Lake West Quadrangle (1955) and Hog Bayou Quadrangle (1955), Topographic Maps, U.S. Geological Survey.

The Gladys McCall Prospect is located in Cameron Parish, Louisiana. The prospect is contained within the Chenier Basin of the Chenier Plain Physiographic Unit. Brackish/intermediate marsh is the predominant habitat type within the study site. Other habitats present include nearshore Gulf, salt marsh, ridge, inland open water, and fresh marsh. This region is characteristically of low topographic relief with scattered recessional beach (chenier) ridges or man-made levees. The local hydrologic regime includes freshwater inputs from shallow groundwater and precipitation, and tidal inundation. Although the Mermentau River and Upper Mud Lake are proximal to the northwest boundary of the projected subsidence bowl, surface water flows from these sources to the study area are effectively diverted by the Grand Chenier Ridge system (Highway 82 ).

The projected subsidence bowl is over 18 kilometers in diameter and extends into the western portion of the Rockefeller Wildlife Refuge and Game Preserve. 


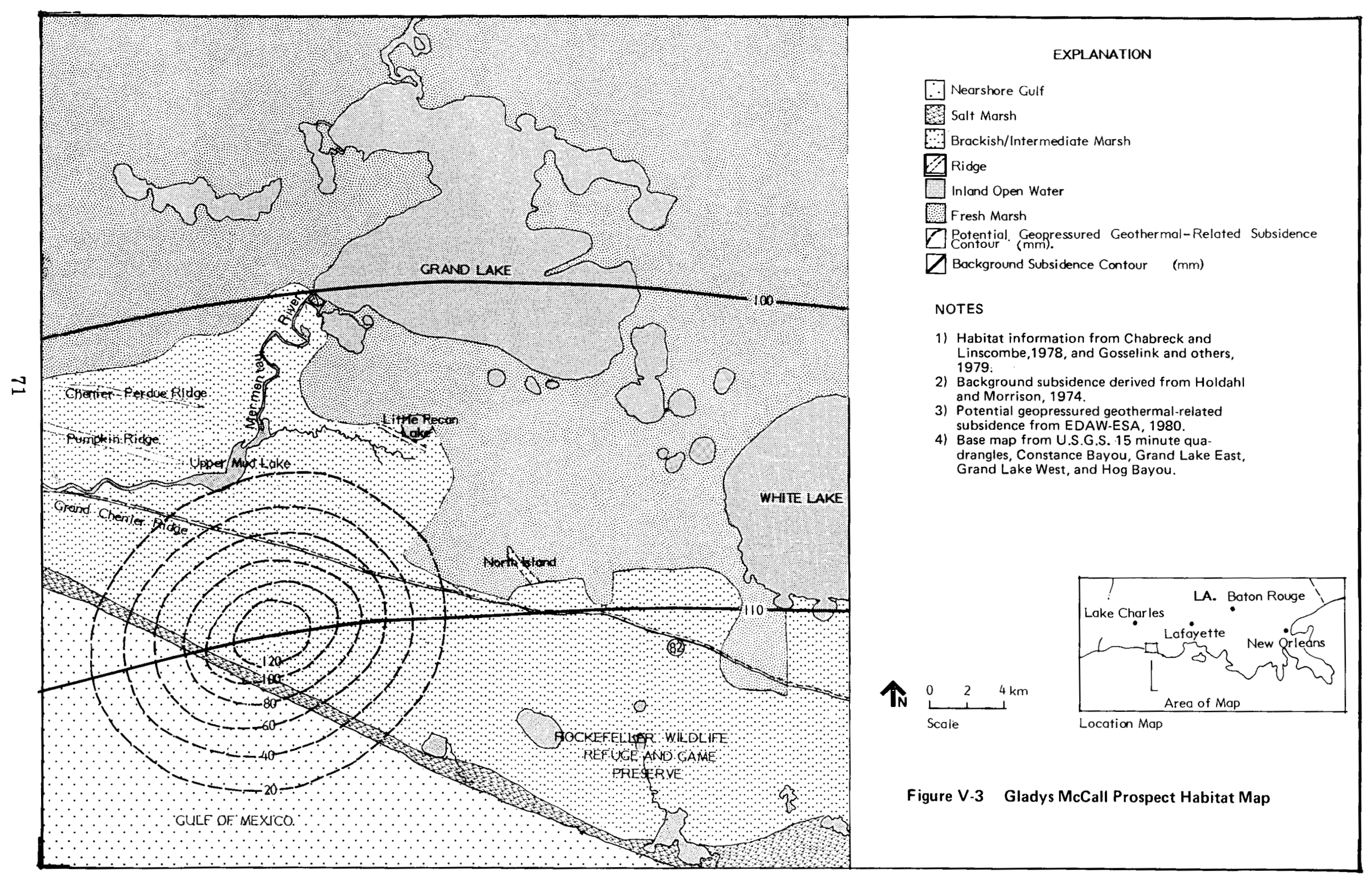


Projected geopressured geothermal-related subsidence rates range from $7.7 \mathrm{~mm} / \mathrm{yr}$ for the first year to $5 \mathrm{~mm} / \mathrm{yr}$ for the last year (Table III-1). The background rate is expected to be $5 \mathrm{~mm} / \mathrm{yr}$. Total projected geopressured geothermal-related subsidence over the estimated 20-year production life is over $100 \mathrm{~mm}$ at the center of the bowl. Total background subsidence projected over the same time period will also be approximately $100 \mathrm{~mm}$.

The projected background subsidence itself will be sufficient to alter significantly the existing habitats within the study area. Indeed, over 200 acres of marsh were converted to open water between 1955 and 1978 . Within the same period, the Gulf shoreline in the prospect area retreated at an average rate of 14.5 meters per year (Van Sickle and Groat, 1981, p. 325). Conversion of salt marsh and brackish/intermediate marsh to open water can be expected as a result of land subsidence and subsequent tidal inundation. Salt marsh will likely invade traditional brackish/intermediate marsh areas. Thus, a net loss of brackish/intermediate marsh is anticipated as a result of background subsidence. The conversion of brackish/intermediate marsh to habitats of lower productivity would likely translate into a net reduction of marsh productivity. Gulfward areas of the brackish/intermediate marsh vegetation complex including Spartina patens,

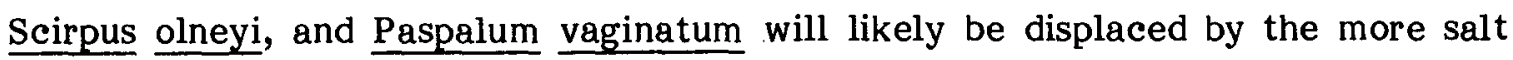
tolerant speices of Spartina alterniflora, Distichlis spicata, and Juncus roemariana. A reduction in brackish/intermediate marsh will mean increased environmental stress (in terms of forage and cover and potentially increased predation and/or competition) for the faunal assemblages associated with this habitat type. The net result will be a decline in ecosystem fitness and potential reduction in recreational and economic wildlife resources.

The total subsidence attributable to geopressured geothermal resource development within the study area will compound the impacts resulting from background subsidence. Increased tidal inundation and additional loss of habitat can be expected. However, much of the potential impact will likely be contained Gulfward of the Grand Chenier Ridge system (which traverses the northern portion of the projected bowl) in an area that will, regardless of resource development, experience significant land loss and habitat alteration. Thus, the significance of the impact associated with the incremental difference between geopressured geothermal and background subsidence will be substantially reduced. 
D. Southeast Pecan Island Prospect

The habitat map presented in Figure V-4 represents a composite summary of information from the following sources: Vegetative Type Map of the Louisiana Coastal Marshes (Chabreck and Linscombe, 1978); An Ecological Characterization Study of the Chenier Plain Coastal Ecosystem of Louisiana and Texas (Gosselink and others, 1979); A Problem Definition Study of Subsidence Caused by Geopressured Geothermal Resource Development (EDAW-ESA, 1980); Pecan Island Quadrangle (1951) and Cheniere Au Tigre Quadrangle (1951), Topographic Maps, U.S. Geological Survey.

The Southeast Pecan Island Prospect is contained within the Vermillion Basin of the Chenier Plain Physiographic Unit in Vermillion Parish, Louisiana. This study area is similar to that of the Gladys McCall Prospect and is comprised of nearshore Gulf, salt marsh, brackish/intermediate marsh, ridge, inland open water, and fresh marsh. Brackish/intermediate marsh is the dominant habitat type. The topography is low relief with little elevational change aside from several chenier ridges and man-made levees. As for the Gladys McCall Prospect, the hydrologic regime includes tidal inundation and freshwater input from precipitation and shallow groundwater.

The projected subsidence bowl is centered near the shoreline in brackish/intermediate marsh. The projected bowl diameter is over 21 kilometers. Projected geopressured geothermal-related subsidence rates range from $14 \mathrm{~mm} / \mathrm{yr}$ for the first year of production to $8 \mathrm{~mm} / \mathrm{yr}$ for the last year of production (Table III-1). The rate of background subsidence is projected to be $6 \mathrm{~mm} / \mathrm{yr}$. Total projected geopressured geothermal-related subsidence over the estimated 20-year lifetime of the prospect is over $200 \mathrm{~mm}$ at bowl center. As is typical of this region, the study area is experiencing substantial background subsidence. The projection for total background subsidence within the area of the bowl and over the same time period is over $100 \mathrm{~mm}$.

Overall impacts attributable to the incremental difference between total background subsidence and total geopressured geothermal-related subsidence will be significant. It is anticipated that the projected high rates and magnitude of geopressured geothermal-related subsidence and the characteristic vulnerability of 


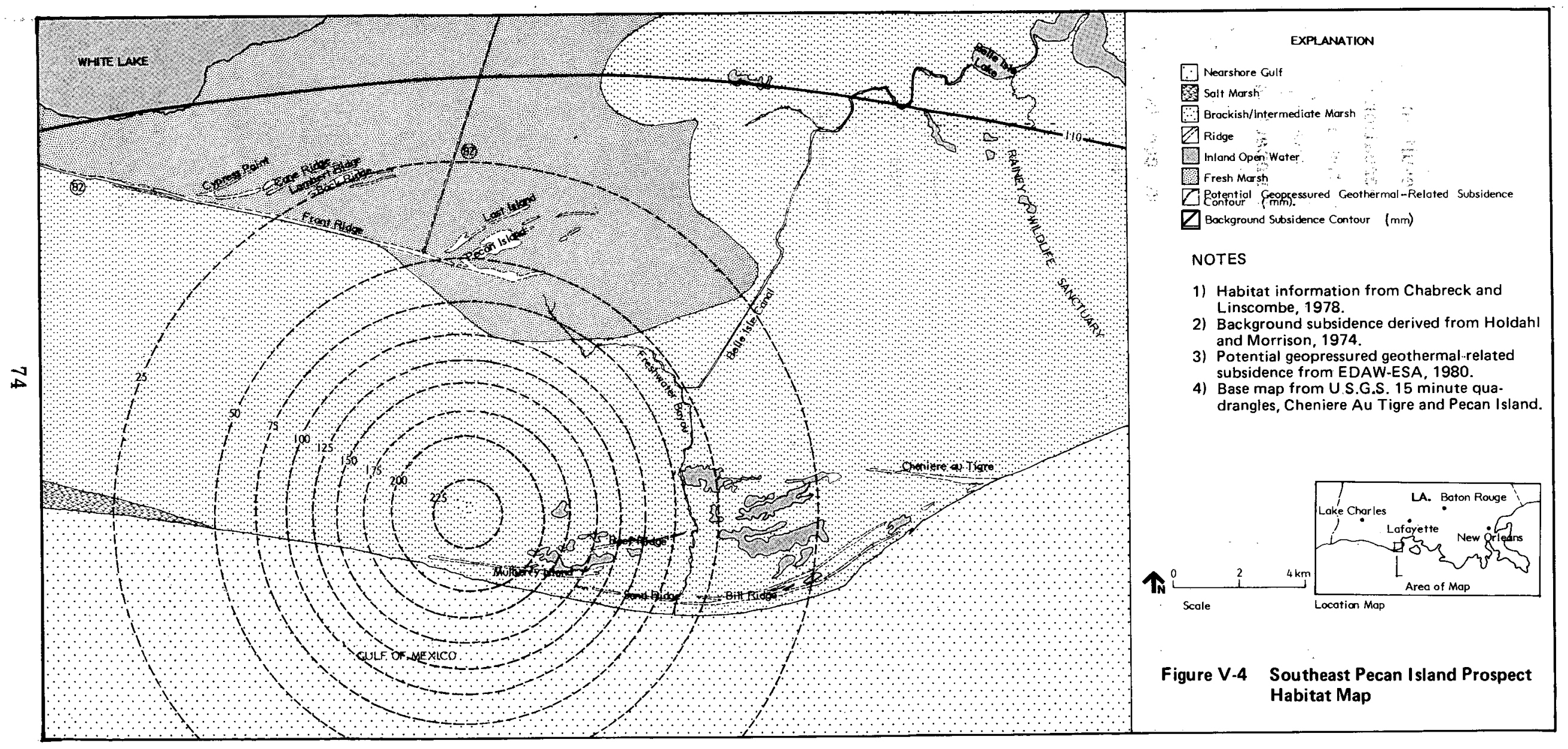


the wetland habitats to subsidence and inundation will result in acceleration of surficial processes, localized ecosystem disruption, and recreational and economic resource loss. The primary ecosystem impact will be the net loss of highly productive brackish/intermediate and fresh marsh habitats due to inundation and increasing salinity. This will result in a commensurate impact upon the faunal assemblages utilizing these habitats.

The complexity and extent of such a disruption can be more clearly understood by tracking the key ecosystem linkages in a systems diagram such as that previously presented in Figure IV-7. As Snyder and others (1978, p. 2) point out, this approach allows the researcher to conceptualize the system's functional relationships in order to identify or predict the possible effects of a specific systems alteration based on a "logical sequence of events". Figure V-5 illustrates the utility of this approach by tracking two cause-and-effect pathways for subsidence of brackish marsh habitat in the Southeast Pecan Island study area. These pathways are necessarily simplified and are only two of several possible pathways that would illustrate the numerous effects of land subsidence within this habitat.

In this example, it is anticipated that a lowering of land elevation due to geopressured geothermal-related subsidence would subject the brackish marsh to increased tidal inundation and tidal frequency. Such an alteration of the existing geohydrologic regime would cause an increase in the proportion of saline water to fresh water in local surface waters and would increase the overall amount of standing water. Subsequently, existing vegetation would be subjected to an increased duration of submergence. Additionally, an increase in surface waters (of higher salinity) would increase the amount of soil macropore water thus raising soil salinity.

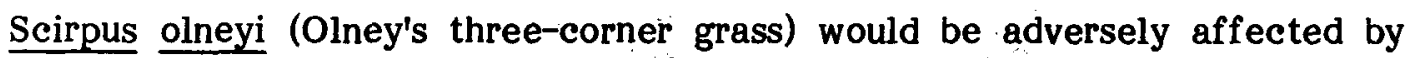
both an increase in the duration of submergence and an increase in soil salinity resulting in a commensurate die-back of this specie in the affected area.

Reduced production and availability of S. olneyi would directly impact those

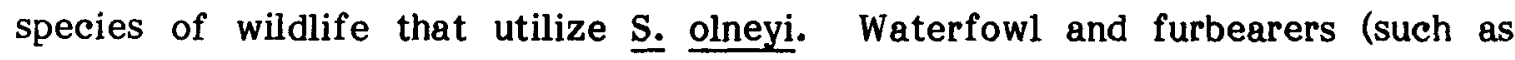
muskrat and nutria) in particular prefer the rhizomes of $\underline{\mathbf{S}}$. olneyi to those of 


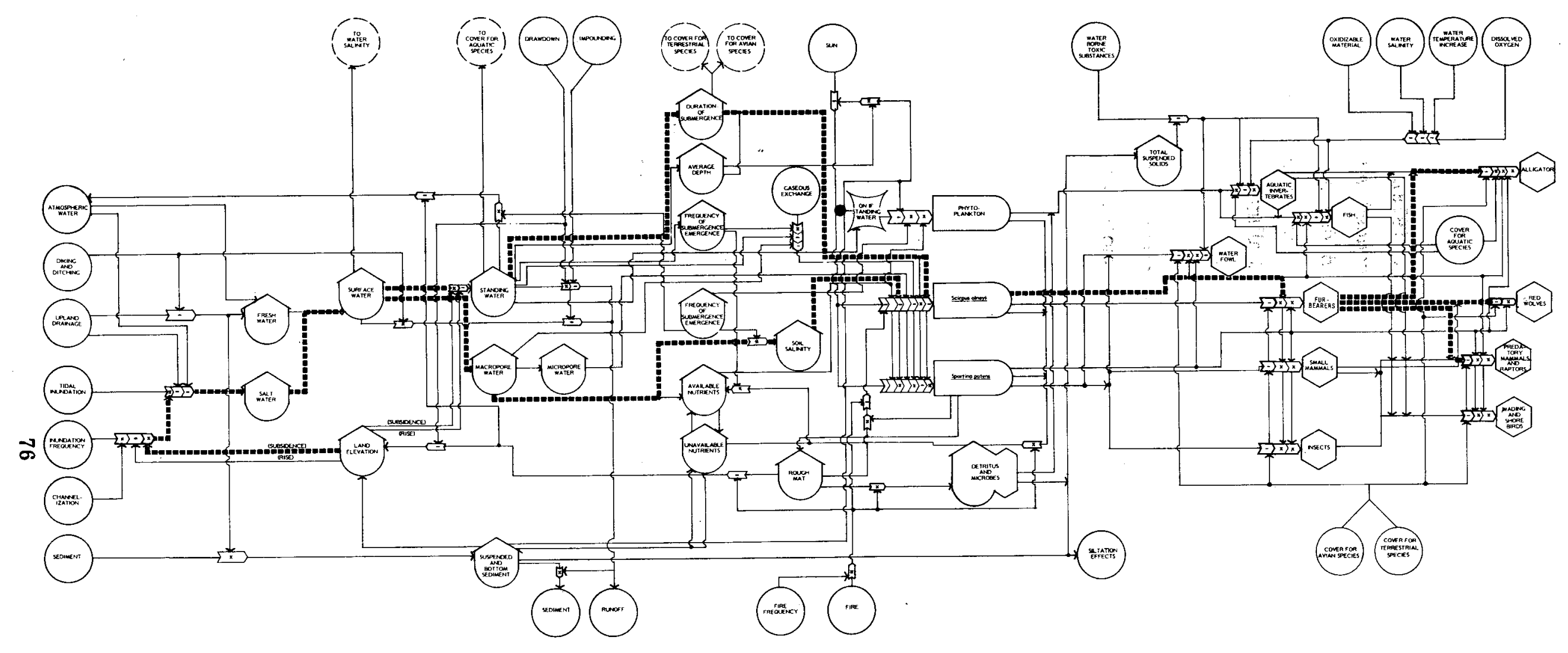

Figure V-5 Two Cause-and-Effect Pathways for Subsidence of Brackish Marsh Habitat in the Southeast Pecan I sland Study 
Spartina patens or Distichlis spicata (Snyder and others, 1978). As a result of increased foraging stress (stress derived from the reduced availability of a preferred forage specie), the population abundances and distributions for these primary consumers would likely change. In turn, the secondary consumers such as predatory mammals (including the red wolf), raptors, and alligators would also be adversely affected.

In summary, due to the range of adverse effects projected, it is anticipated that the Southeast Pecan Island prospect would incur the most significant environmental impacts of the four study areas. 



\section{REFERENCES CITED}

Adams, D. A., 1963, Factors influencing vascular plant zonation in North Carolina salt marshes: Ecology, v. 44, no. 3, p. 445-456.

Adkins, G., 1972, A study of the blue crab fishery in Louisiana: Louisiana Wildlife and Fisheries Commission, New Orleans, Louisiana, 57 p.

Bahr, L. M., Jr., Day, J. W., Jr., Gayle, T., Gosselink, J. G., Hopkinsỏn, C. S., Stellar, D., and Harris, J., 1977, Construction of a conceptual model of the Chenier Plain coastal ecosystem in Texas and Lousiana, in Hall, C. S., and Preston, W., compilers, Program review procedures of: environmental effect of energy related activities on marine estuarine ecosystems: U.S. Environmental Protection Agency, Report no. EPA-660/7-77-111, p. 75-92.

Boyce, S. G., 1954, The salt spray community: Ecological Monographs, v. 24, no. 1 , p. 29-67.

Bureau of Economic Geology, 1975, Land and water resources, Houston-Galveston Area Council: The University of Texas at Austin, map scale 1:250,000.

Bureau of Economic Geology, 1977, Land resources of Texas: The University of Texas at Austin, map scale 1:500,000.

Bureau of Economic Geology, 1980, Draft environmental analysis of geopressured geothermal prospect areas in Colorado and DeWitt Counties, Texas: The University of Texas at Austin.

Chabreck, R. H., 1972, Vegetation, water and soil characteristics of the Louisiana coastal region: Baton Rouge, Louisiana, Agriculture Experimental Station, Louisiana State University, 72 p.

Chabreck, R. H., and Linscombe, G., 1978, Vegetative type map of the Louisiana coastal marshes: Louisiana Dept. of Wildlife and Fisheries, map scale $1: 375,000$.

Chapman, V. J., 1940, Studies in salt marsh ecology - Sections VI and VII Comparison with the marshes on the east coast of North America: Ecology, v. 28 , p. 118-152.

Chapman, V. J., 1960, Salt marshes and salt deserts of the world: New York, New York, Interscience Publishers, 392 p.

Clapham, W. B., Jr., 1973, Natural Ecosystems: New York, New York, MacMillan Company, 248 p.

Clark, J., 1974, Coastal ecosystems, ecological considerations for management of the coastal zone: Washington, D.C., The Conservation Foundation, 178 p.

Coastal Environments, Inc., 1976, An environmental assessment of proposed geothermal well testing in the Tigre Lagoon Field, Vermillion Parish, Louisiana: Baton Rouge, Louisiana, with the Energy Research and Development Administration, Division of Geothermal Energy, Washington, D.C., $104 \mathrm{p}$. 
Conner, W. H., and Day, J. W., Jr., 1976, Productivity and composition of a baldcypress-water tupelo site and bottomland hardwood site in a Louisiana swamp: American Journal of Botany, v. 63, no. 10, p. 1354-1364.

Copeland, B. J., 1970, Estuarine classification and responses to disturbances: Transactions of the American Fisheries Society, v. 99, no. 4, p. 826-835.

Cottam, C., Bourn, W. S., Bishopp, F. C., Williams, L. L., Jr., and Vogt, W., 1938, What's wrong with mosquito control?: Transactions of the North American Wildlife Conference, v. 3, p. 81-107.

Cottam, C., and Bourn, W. S., 1952, Coastal marshes adversely affected by drainage and drought: Transactions of the North American Wildlife Conference, v. 17, p. 414-420.

Cowardin, L. M., Carter, Virginia, Golet, F. C., and LaRoe, E. T., 1979, Classification of wetlands and deepwater habitats of the United States: Washington, D.C., U.S. Fish and Wildlife Service, 103 p.

Craig, N. J., and Day, J. W., Jr., eds., 1977, Cumulative impact studies in the Louisiana Coastal zone: eutrophication, land loss: Louisiana State University, Baton Rouge, Louisiana, 157 p.

Craig, N. J., Turner, R. E., and Day, J. W., Jr., 1979, Land loss in coastal Louisiana (U.S.A.): Environmental Management, v. 3, no. 2, p. 133-144.

Cronin, L. E., ed., 1975, Estuarine Research - Vol. 1: New York, New York, Academic Press, 738 p.

Cross, R. D., and Williams, D. L., eds., 1981, Proceedings of the national symposium on freshwater inflow to estuaries - Vol. 1: Washington, D.C., U.S. Fish and Wildlife Service, 525 p.

Daiber, F. C., 1974, Salt marsh plants and future coastal salt marshes in relation to animals, in Reimold, R. J., and Queen, W. H., eds., Ecology of Halophytes: New York, New York, Academic Press, p. 475-508.

Daigh, F. C., MacCreary, D., and Sterns, L. A., 1938, Factors affecting the vegetation cover of Delaware marshes, in Proceedings of the New Jersey Mosquito Extermination Association: v. 25, p. 209-216.

Day, J.W., Jr., Smith, W. A., Wagner, P. R., and Stowe, W. C., 1973, Community structure and carbon budget of a salt marsh and shallow bay estuarine system in Louisiana: Louisiana State University, Center for Wetland Resources, Baton Rouge, Louisiana, Publication no. LSU-SG-72-04, 79 p.

Dunham, F., 1972, A study of commercially important estuarine-dependent industrial fishes: Louisiana Wild Life and Fisheries Commission, New Orleans, Louisiana, 63 p.

Earle, D. W., Jr., 1972, Problems of Wetland Urbanization. 
EDAW-ESA, 1980, A problem definition study of subsidence caused by geopressured geothermal resource development: Geothermal Subsidence Research Management Program, Earth Sciences Division, Lawrence Berkeley Laboratory, Berkeley, California, GSRMP-10, LBL-12392, 186 p.

Eleuterius, L. N., and Eleuterius, C. K., 1979, Tide levels and salt marsh zonation: Bulletin of Marine Science, v. 29, no. 3, p. 394-400.

Fisher, W. L., McGowen, J. H., Brown, L. F., Jr., and Groat, C. G., 1972, Environmental geologic atlas of the Texas coastal zone, Galveston-Houston area: The University of Texas at Austin, Bureau of Economic Geology, 91 p.

Gabrysch, R. K., 1980, Approximate land-surface subsidence in the HoustonGalveston region, Texas 1906-78, 1943-78, and 1973-79: U.S. Geol. Survey Open-File Report 80-338.

Gagliano, S. M., and van Beek, J. L., 1970, Hydrologic and geologic studies of coastal Louisiana - Report No. 1: Geologic and geomorphic aspects of deltaic processes, Mississippi Delta System: Louisiana State University, Center for Wetland Resources, Baton Rouge, Louisiana, 140 p.

Gaidry, W. J., III, and White, C. J., 1973, Investigations of commercially important penaeid shrimp in Louisiana estuaries: Louisiana Wild Life and Fisheries Commission, New Orleans, Louisiana, 154 p.

Geertsma, J., 1973, Land subsidence above compacting oil and gas reservoirs: Journ. Pet. Tech., v. 25, p. 734-744.

Gosselink, J. G., 1970, Growth of S. patens and S. alterniflora as influenced by salinity and source of nitrogen: Coastal Studies Bulletin, Louisiana State University, Center for Wetland Resources, Baton Rouge, Louisiana, no. 5.

Gosselink, J. G., and Hebrard, J. J., 1977, Threatened, endangered, and extinct species in the Chenier Plain, in Day, J. W., Jr., Culley, D. D., Turner, R. E., and Mumphrey, A. J., Jr., eds., Proceedings of the Third Coastal Marsh and Estuary Management Symposium, Louisiana State University, Baton Rouge, p. 393-415.

Gosselink, J. G., Cordes, C. L., and Parsons, J. W., 1979, An ecological characterization study of the Chenier Plain coastal ecosystem of Louisiana and Texas: U.S. Fish and Wildlife Service, v. 1, Narrative report, report no. FWS/OBS-78/9, 302 p.; v. 2, Appendices, report no. FWS/OBS-78/10, 407 p.

Green, J., 1968, The biology of estuarine animals: University of Washington, Seattle, Washington.

Gunter, G., Christmas, J. Y., and Killebrew, R., 1964, Some relations of salinity to population distributions of motile estuarine organisms, with special reference to penaeid shrimp: Ecology, v. 45, no. 1, p. 181-185. 
Gustavson, T.C., 1979, Environmental baseline monitoring in the area of General Crude Oil-Department of Energy Pleasant Bayou Number 1--A geopressuredgeothermal test well-1978, Introduction and technical report, Annual Report: The University of Texas at Austin, Bureau of Economic Geology, v. 1,33 p.

Gustavson, T. C., Howard, R. C., and McGookey, Douglas, 1980, Environmental baseline monitoring in the area of General Crude Oil - Department of Energy Pleasant Bayou Number 2 - A geopressured geothermal test well - 1979, Annual report, vol. 2: The University of Texas at Austin, Bureau of Economic Geology, 245 p.

Holdahl, S. R., and Morrison, N. L., 1974, Regional investigations of vertical crustal movements in the U.S., using precise relevelings and mareograph data: Tectonophysics, v. 23, p. 373-390.

Hopkins, S. H, 1973, Annotated bibliography on effect of salinity and salinity changes on life in coastal waters: U.S. Army Waterways Experiment Station, Vicksburg, Mississippi, Contract Report H-73-2, 411 p.

Janssen, J. C., and Carver, D. R., 1981, A computer program for predicting surface subsidence resulting from pressure depletion in geopressured wells Subsidence prediction for the DOE test well no. 1, Parcperdue, Louisiana, in Proceedings, Fifth Conference, Geopressured-Geothermal Energy, U.S. Gulf Coast, Baton Rouge, p. 281-284.

Kirby, C. J., and Gosselink, J. G., 1976, Primary production in a Louisiana Gulf Coast Spartina alterniflora marsh: Ecology, v. 57, no. 5, p. 1052-1059.

Kreitler, C. W., and Gustavson, T. C., 1976, Geothermal resources of the Texas Gulf Coast, in Vanston, J. H., and others, eds., Geopressured Geothermal Energy Conference, 2nd, Austin, February 23-25, 1976, Proceedings: The University of Texas at Austin, Center for Energy Studies, v. 5, part 3, 55 p.

Lagna, L., 1975, The relationship of Spartina alterniflora to mean high water: State University of New York, Marine Sciences Research Center, Stony Brook, New York.

Mayer, F. L., Jr., and Low, J. B., 1970, The effect of salinity on widgeon grass: Journal of Wildlife Management, v. 34, no. 3, p. 658-661.

McMillan, C., and Moseley, F. N., 1967, Salinity tolerances of five marine spermatophytes of Redfish Bay, Texas: Ecology, v. 48, no. 3, p. 503-506.

Miller, W. R., and Egler, F. E., 1950, Vegetation of the Wequetequock-Pawcatuk tidal marshes, Connecticut: Ecology Monographs, v. 20, p. 143-172.

Montz, G. N., 1977, Vegetational study, Timbalier Isles Dernieres barrier islands: Proceedings, Louisiana Academy of Science, v. 40, p. 59-69.

Morgan, J. P., 1967, Ephemeral estuaries of the deltaic environment, in Lauff, G. H., ed., Estuaries: American Association for the Advancement of Science, p. 115-120. 
Morgan, J. P., 1972, Impact of subsidence and erosion on Louisiana coastal marshes and estuaries: Coastal Marsh \& Estuary Management Symposium, Baton Rouge, Louisiana State University, p. 217-233.

Odum, E. P., and de la Cruz, A. A., 1967, Particulate organic detritus in a Georgia salt marsh-estuarine ecosystem, in Lauff, G. H., ed., Estuaries: Washington, D.C., American Association for the Advancement of Science, Publication no. 83 , p. 383-388.

Odum, H. T., Kemp, W., Sell, M., Boynton, W., and Lehman, M., 1977, Energy analysis and the coupling of man and estuaries: Environmental Management, v. 1 , no. 4, p. 297-315.

Odum, W. E., 1970, Insidious alteration of the estuarine environment: Transactions of the American Fisheries Society, v. 99, no. 4, p. 836-847.

Parker, J. C., 1970, Distribution of juvenile brown shrimp (Penaeus aztecus Ives) in Galveston Bay, Texas, as related to certain hydrographic features and salinity: Contributions in Marine Science, v. 15, p. 1-12.

Parker, R. H., 1955, Changes in the invertebrate fauna, apparently attributable to salinity changes, in the bays of central Texas: Journal of Paleontology, v. 29, no. 2, p. 193-211.

Penfound, W. T., and Hathaway, E. S., 1938, Plant communities in the marshlands of southeastern Louisiana: Ecology Monographs, v. 8, p. 1-56.

Perrett, W. S., Barrett, B. B., Latapie, W. R., Pollard, J. F., Mock, W. R., Adkins, G. B., Gaidry, W. J., and White, C. J., 1971, Cooperative Gulf of Mexico estuarine inventory and study, Louisiana - Phase I, Area Description and Phase IV, Biology: Louisiana Wildlife and Fisheries Commission, New Orleans, Louisiana, $175 \mathrm{p}$.

Proctor, C. M., Garcia, J. C., Galvin, D. V., Lewis, G. C., and Massa, A. M., 1980, An ecological characterization of the Pacific Northwest Coastal Region Volume 1 - Conceptual model: U.S. Fish and Wildlife Service, Report no. FWS/OBS-79/11.

Queen, W. H., 1975, Halophytes: adaptive mechanisms, in Vernberg, F. J., ed., Physiological ecology of esturine organisms: Columbia, South Carolina, University of South Carolina Press, p. 205-211.

Ratzlaff, K. W., 1980, Land-surface subsidence in the Texas coastal region: U.S. Geol. Survey Open-File Report 80-969, Austin, Texas Department of Water Resources.

Sasser, C. E., 1977, Distribution of vegetation in Louisiana coastal marshes as response to tidal flooding: M.S. thesis, Louisiana State University, Baton Rouge.

Seneca, E. D., 1969, Germination response to temperature and salinity of four dune grasses from the outer banks of North Carolina: Ecology, v. 50, no. 1, p. 4553. 
Sklar, F. H., and Conner, W. H., 1979, Effects of altered hydrology on primary production and aquatic animal populations in a Louisiana swamp forest, in Day, J. W., Jr., Culley, D. D., Jr., Turner, R. E., and Mumphrey, A. J., Jr., Proceedings of the Third Coastal Marsh and Estuary Management Symposium: Louisiana State University, Baton Rouge, Louisiana, p. 191-208.

Smalley, A. E., 1959, The role of two invertebrate populations, Littorina irrorata and Ochelimum fidicinium in the energy flow of a salt marsh ecosystem: University of Georgia, Athens, Georgia, Ph.D. thesis, 126 p.

Smith, W. G., 1970, Spartina "die-back" in Louisiana marshes: Coastal Studies Bulletin, Louisiana State University, no. 5, p. 89-95.

Snyder, B. W., Longley, W., and Jackson, R., 1978, Ecological system diagrams: theory and construction-activity assessment routine ecological systems component: Texas Coastal Management Program Technical Paper, Austin, General Land Office of Texas, no. 12, 91 p.

Texas Department of Water Resources, 1979a, Draft report, Guadalupe Estuary: a study of the influence of freshwater inflows: Austin, Texas.

Texas Department of Water Resources, $1979 \mathrm{~b}$, The influence of freshwater inflows upon the major bays and estuaries of the Texas Gulf Coast, Executive Summary: Austin, Texas.

Texas Water Development Board, 1974, a completion report on techniques for evaluating the effects of water resources development on estuarine environments: Austin, Texas.

Texas Water Development Board, 1977, ESTECO-Estuarine aquatic ecologic model: Austin, Texas.

Todd, D. K., 1980, Groundwater Hydrology: New York, New York, John Wiley and Sons, 535 p.

Van Sickle, J. R., Barrett, B. B., Ford, T. B., and Gulick, L. J., 1976, Barataria Basin: salinity changes and oyster distribution: Louisiana State University, Baton Rouge, Louisiana, Center for Wetland Resources, 22 p.

Van Sickle, J. R., and Groat, C. G., 1981, Subsidence and induced faulting: key environmental issues in geopressured geothermal resource development: Proceedings, Fifth Conference, Geopressured-Geothermal Energy, U.S. Gulf Coast, Baton Rouge, p. 325-330.

Viets, V. F., Vaughan, C. K., and Harding, R. C., 1979, Environmental and economic effects of subsidence: Geothermal Subsidence Research Management Program, Berkeley, California, Lawrence Berkeley Laboratory, Earth Sciences Division, Report no. GSRMP-1, LBL-8615.

Wallace, R. H., Jr., 1981, The Design-Well site-selection process: Proceedings, Fifth Conference, Geopressured-Geothermal Energy, U.S. Gulf Coast, Baton Rouge, Louisiana, p. 223-225. 
Ward, G. H., Jr., and Armstrong, N. E., 1979, Studies of the effects of alterations of freshwater inflows into Matagorda Bay Area, Texas, Phase I Final Report: Austin, Texas; Espey, Huston and Associates, Inc., 391 p.

Webb, K. L., 1965, $\mathrm{NaCl}$ effects on growth and transportation in Salicornia bigelovii a salt-marsh halophyte: Plant and Soil, v. 23, no. 2, p. 261- 268 .

West, D., (in press), Saltwater intrusion in the Louisiana coastal zone: Louisiana Coastal Zone Management Plan, Louisiana State Planning Office, 51 p.

White, W. A., McGraw, Maryann, and Gustavson, T. C., 1978, Environmental analysis of geopressured-geothermal prospect areas, Brazoria and Kenedy Counties, Texas: Austin, The University of Texas at Austin, Bureau of Economic Geology, for the U.S. Dept. of Energy, Division of Geothermal Energy, 203 p.

Zein-Eldin, Z. P., 1963, Effect of salinity of growth of postlarval penaeid shrimp: Biological Bulletin, v. 125, no. 1, p. 188-196. 


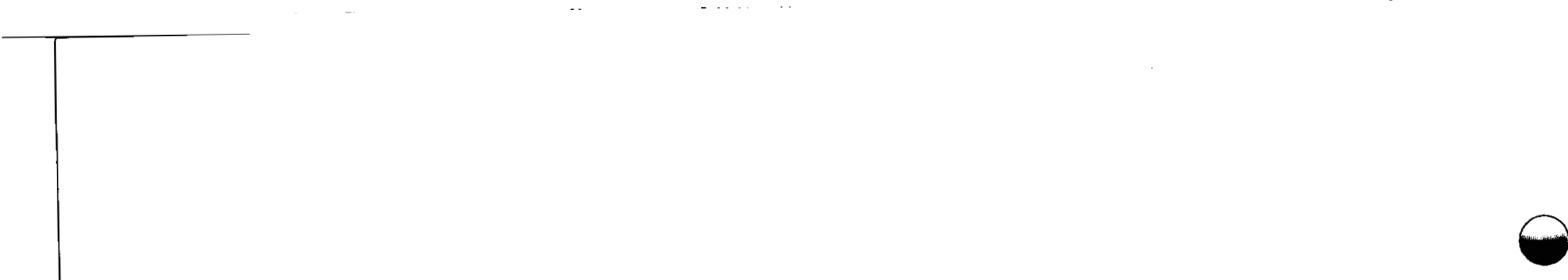

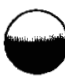

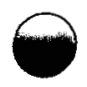


Appendix

BACKGROUND SUBSIDENCE RATES

$A-i$ 
0

$\bullet$ 
TABLE OF CONTENTS

LIST OF FIGURES $\quad$ A- v

LIST OF TABLES A-vi

I. INTRODUCTION A-

A. Purpose A-1

B. Credible Rates of Subsidence A-2

C. Scope A-4

D. Sources A-4

II. GEOLOGIC HISTORY OF THE GULF COAST - A SUMMARY A- 5

III. NATURAL SUBSIDENCE PROCESSES A- 7

$\begin{array}{ll}\text { A. Basement Downwarping } & \text { A- } 7\end{array}$

B. Movement of Growth Faults $\quad A-10$

C. Consolidation and Depression of $\quad A-10$

Pleistocene and Tertiary Sediments

D. Consolidation of Holocene Deposits A-15

E. Eustatic Sea Level Rise A-20

F. Local Consolidation $\quad A-21$

G. Uplift A-21

IV. MAN-INDUCED SUBSIDENCE PROCESSES A-23

A. Groundwater Withdrawal A-23

B. Oil and Gas Production A-35

$\begin{array}{ll}\text { C. Solution Mining } & \text { A-39 }\end{array}$ 
D. Peat Deflation

E. Local Consolidation

A-44

F. Hydrofracturing

A -44

V. TOTAL BACKGROUND SUBSIDENCE RATES

$A-45$

VI. REFERENCES CITED

A-49 


\section{LIST OF FIGURES}

A-1 Continental Separation-Triassic-Early Jurassic

A- 6

A-2 Generalized Cross Section of Gulf Coast Geosyncline

A- 8

Depicting Components of Natural Subsidence

A-3 Rates of Subsidence Caused by Basement Downwarping-

A- 9

Texas

A-4 Rates of Subsidence Caused by Basement DownwarpingLouisiana

A-5 Principal Regional Faults and Landward Northern Boundary of Miocene Deposits in the Gulf Coast Geosyncline

A-6 Diagrammatic Cross Section Across the Gulf Coast Geosyncline

A-7 Rates of Subsidence Caused by Fault Movements--Louisiana

A-8 Rates of Subsidence Caused by Depression of Pleistocene and Tertiary Sediments in Mississippi Delta Area-Louisiana Northern Gulf of Mexico

A-10 Rates of Subsidence Caused by Consolidation of Holocene Deposits--Louisiana

A-11 Generalized Cross Section of Gulf Coast Geosyncline Depicting Components of Man-Induced Subsidence

A-12 Location of Texas Subregions

A-13 Rates of Subsidence Caused by Man-Induced ProcessesTexas-Subregion 2

A-14 Rates of Subsidence Caused by Man-Induced ProcessesTexas-Subregion 3

A-15 Rates of Subsidence Caused by Man-Induced ProcessesTexas-Subregion 5 


\section{LIST OF FIGURES (Continued)}

A-17 Rates of Subsidence Caused by Man-Induced ProcessesA-33 Louisiana

A-18 Distribution of Peat--Louisiana

A-19 Distribution and Thickness of Peat Deposits in the Vicinity of A-41 New Orleans-Louisiana

A-20 Approximate Subsidence History and Estimated Future Subsidence for Area in Kenner, Louisiana, Northern Part of Local Subsidence Basin

A-21 Background Rates of Subsidence-Texas

A-22 Background Rates of Subsidence-Louisiana 


\section{INTRODUCTION}

\section{A. $\quad$ Purpose}

The present geologic environment of the Texas-Louisiana Gulf Coast is not static. Subsidence is presently occurring as a result of several natural and maninduced processes. Any vertical ground movement caused by geopressured geothermal resource development would be superimposed on these background processes. Before the significance of potential additional subsidence in the Gulf Coast area can be determined, the rates and distribution of background subsidence must be established. Although the separation of the various phenomena that contribute to the total background subsidence is difficult, the separation should be attempted in order to delineate the cause(s) of background subsidence in particular areas of interest in the Gulf Coast. Accordingly, the objectives of this Appendix are:

- To determine the rate and distribution of background subsidence in the Texas-Louisiana Gulf Coast, and

- To differentiate rates of subsidence caused by different processes.

The processes which contribute to, or affect, background subsidence in the Gulf Coast are listed below.

\section{Natural Processes}

- Basement downwarping

- Movement of growth faults

- Consolidation ${ }^{1}$ and depression of Pleistocene and Tertiary sediments

Consolidation, as used in this Appendix, will carry the soil mechanics definition, i.e. "... the adjustment of a saturated soil to increased load. Involves the squeezing of water from the pores and decrease in void ratio." (Trowbridge, 1962). This definition is in contrast to the geologic definition of consolidation, which is, "Any or all of the processes whereby loose, soft or liquid earth materials become firm and coherent." (Trowbridge, 1962). 
- Consolidation of Holocene sediments

- Eustatic sea level rise

- Local consolidation

- Uplift

Man-Induced Processes

- Groundwater withdrawal

- Oil and gas production

- Solution mining

o Peat deflation

- Local consolidation

- Hydrofracturing

\section{B. Credible Rates of Subsidence}

Background rates of subsidence change with time owing to fluctuations in subsidence processes. For example, groundwater pumpage varies according to human needs; sedimentation rates and distribution fluctuate throughout geologic time; and growth fault activity in the Gulf Coast is variable. Any of these fluctuations cause variation in the subsidence rate over time. So the question arises as to which rate will be characteristic of the background rate during the production life (about 20 years) of a geopressured geothermal well, i.e., what will determine a credible subsidence rate?

For this study, no one time period has been used to calculate subsidence rates. Instead, credible average rates for each subsidence process have been determined by dividing the total amount of subsidence by the total time over which it occurred, with the time period used depending on the subsidence process. For long-term processes such as basement downwarping and growth fault movement, a very long time period has been chosen (see Table A-1). For more recently initiated processes such as groundwater withdrawal, a short time period has been chosen. The credible rates shown in Figures A-21 and A-22, therefore, are the averaged rates over the most recent time span for which data are available, for areas where subsidence is expected to continue for at least the next 20 years. 
TABLE A-1

Time Periods Used for Calculating Background Subsidence Rates

Subsidence Process

(2-65 MY)

Long Term

$(5000 \mathrm{Y})$

Short Term

(300. Y)

Historic

$(20-50 \mathrm{Y})$

Future

$\underline{\text { Natural Processes }}$

Basement

Downwarping

$\mathbf{x}$

Growth Fault

Movement

$\mathbf{x}$

Consolidation and

Depression of

Pleistocene and

Tertiary Sediments

$\mathbf{x}$

Consolidation of

Holocene Sediments

$\mathrm{x}$

$\mathbf{x}$

$\mathbf{x}$

Eustatic Sea Level

Rise

$\mathbf{x}$

Local Consolidation

$x$

Uplift

$\mathbf{x}$

Man-Induced Processes

Groundwater

Withdrawal

$\mathbf{x}$

Oil and Gas

Production

Solution Mining

$\mathbf{x}$

Peat Deflation

$\mathbf{x}$

$\mathbf{x}$

Local Consolidation

x

Hydrofracturing

$\mathbf{x}$ 
For Atchafalaya Bay, Louisiana, and Houston, Texas, some idea of the trend of future rates is available. These future trends are discussed in Appendix Sections III.D. and IV.A., respectively, and were considered in assigning credible subsidence rates to these two areas. In Atchafalaya Bay, where rates are expected to increase in the future, the credible rate assigned is slightly higher than the highest rate yet published. In and around Houston, rates may increase in some areas and decrease in others, depending on groundwater usage. Because of the uncertainty of future rates near Houston, the average rate over the last five-year period available (19731978 ) is deemed credible for the purposes of this study.

\section{Scope}

Section II of this appendix gives a summary of the geologic history of the Gulf Coast geosyncline. A knowledge of this history is necessary in order to understand why natural subsidence is now occurring in the Gulf Coast. Ensuing sections contain descriptions of the natural and man-induced subsidence processes and discussions of the rates and distribution attributed to each process. Maps showing the rates and distribution of the various subsidence processes are also included. In addition to subsidence rates, these maps show the location of the geopressured geothermal prospects discussed in the main body of the report, prospects for which a Design Well has already been designated, and prospects currently favored as sites of future Design Wells. The summary includes a composite map for both Texas and Louisiana showing all types of background subsidence now occurring.

\section{Sources}

The rates of subsidence presented in this report were obtained from published literature, unpublished reports, and calculations made from published and unpublished data. 


\section{GEOLOGIC HISTORY OF THE GULF COAST - A SUMMARY}

About three hundred million years ago (during the Pennsylvanian Period) what is now known as North America, South America, Eurasia, and Africa formed a single megacontinent called Pangea. During the Triassic-Early Jurassic Periods, approximately 225 million years before present (MYBP), this megacontinent started to break apart, one break line being near the present-day shoreline of the Gulf of Mexico. Before this break line was finally established, spreading centers started to form in other areas, but died out before they actually rifted apart. These abandoned spreading centers are called aulocogens (Figure A-1). Continued spreading along the main break line formed the present Gulf of Mexico.

Throughout the spreading period, which ended at the close of the Early Cretaceous (approximately $100 \mathrm{MYBP}$ ), and on through the rest of the Cretaceous, the edge of the North American plate acted as a trailing plate margin and subsided somewhat as a whole due to a complex combination of processes, probably including crustal thinning, flow of subcrustal material, and thermal contraction.

At the end of the Cretaceous (approximately 65 MYBP), the Laramide Orogeny began. During this period, mountains were formed in the interior of the North American continent. Erosion of these uplands produced a vast amount of sediments which was carried away by rivers. The Mississippi and Rio Grande aulocogens served as conduits for the rivers, directing large amounts of sediments into the Gulf of Mexico.

From the beginning of this erosional period to the present, the old edge of the North American plate has acted as a vast sediment trap, creating what is now known as the Gulf Coast geosyncline. This geosyncline contains a wedge of sediments about 12 kilometers thick. It is in these sediments that the geopressured geothermal resources lie, and it is also largely because of the sediments and their location on the weakened edge of an ancient plate margin that natural subsidence is now occurring in the Gulf Coast. 


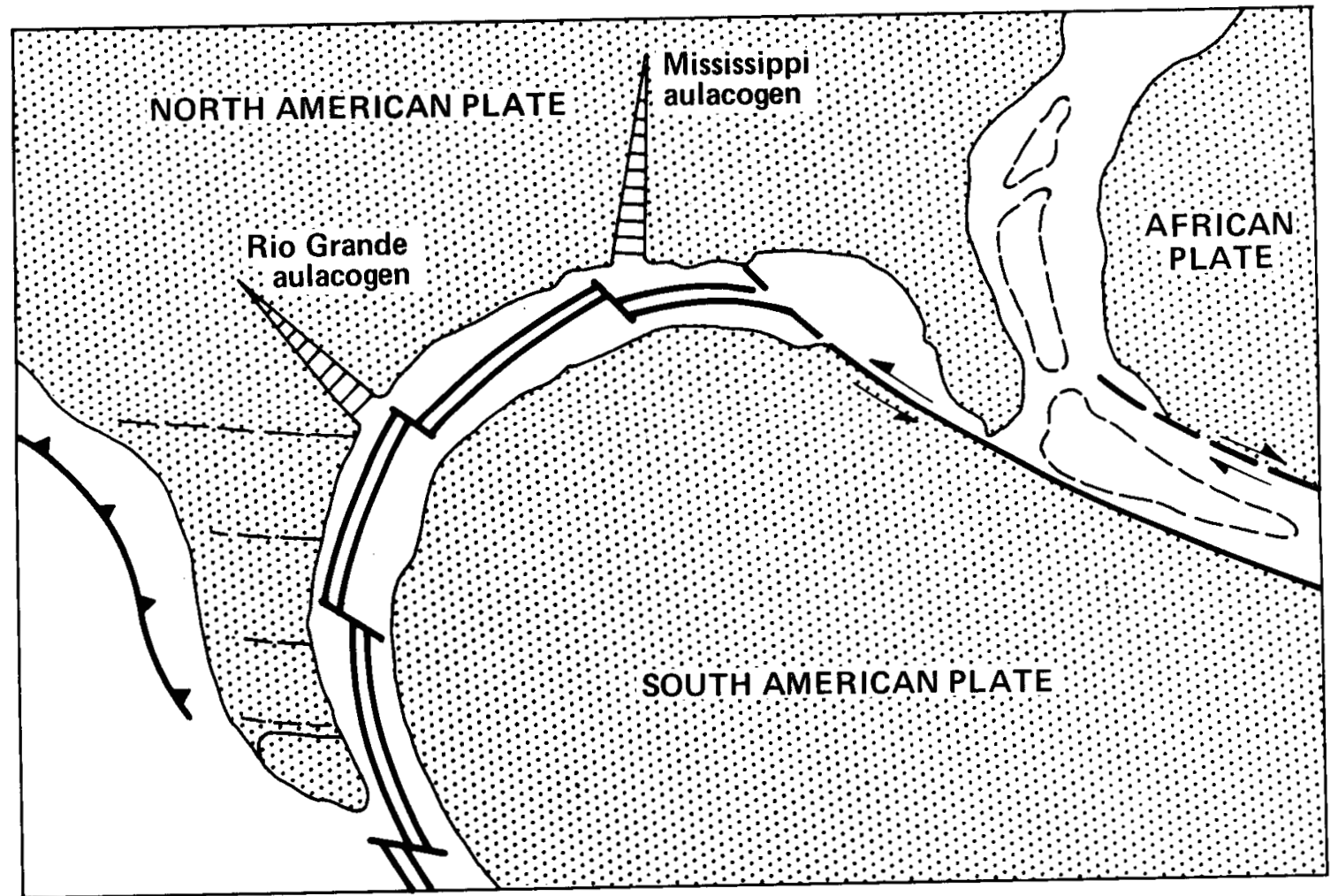

Figure A-1 Continental Separation - Triassic - Early Jurassic 
Appendix

III. NATURAL SUBSIDENCE PROCESSES

Natural subsidence is the result of several processes. Figure A-2 depicts a generalized cross section of the Gulf Coast geosyncline and displays the following components of natural subsidence: basement downwarping, growth fault movement, consolidation and depression of Pleistocene and Tertiary sediments, consolidation of Holocene sediments, eustatic sea level rise, local consolidation, and uplift. Note, on Figure A-2, that the Holocene sediments, although as much as 300 meters thick, form only a relatively thin deposit capping 12 kilometers of Pleistocene and Tertiary sediments. Each component of natural subsidence is discussed below.

\section{A. Basement Downwarping}

As mentioned previously, a wedge of shallow water sediments about 12 kilometers thick has been accumulating in the Gulf Coast geosyncline since the beginning of the Tertiary (approximately 65 MYBP). This thick section of sediments accumulated in part through downwarping of the underlying crust. Downwarping results from a complex combination of processes including sediment loading, crustal thinning, and flow of subcrustal material.

Although rates fluctuated throughout time, a simple calculation gives an average maximum rate of basement downwarp over the last $65 \mathrm{MY}$ as approximately $0.2 \mathrm{~mm} / \mathrm{yr}$. From geologic cross sections across the Texas coastal plain (Bebout and others, 1976; Baker, 1978) the rate of downwarp of the basement surface (the Mesozoic/Cenozoic boundary) can be mapped in some detail (Figure A-3). Rates increase toward the Gulf but, because the basement surface dips off the cross sections near the coast, only the more inland rates were calculated. The effects of fault movement are included in the rates shown in Figure A-3.

The same procedure was followed with geologic cross sections (Louisiana Geological Survey, 1981) of the western Louisiana coastal plain. Cross sections for the eastern coastal plain have not yet been drafted (D. G. Bebout, personal 


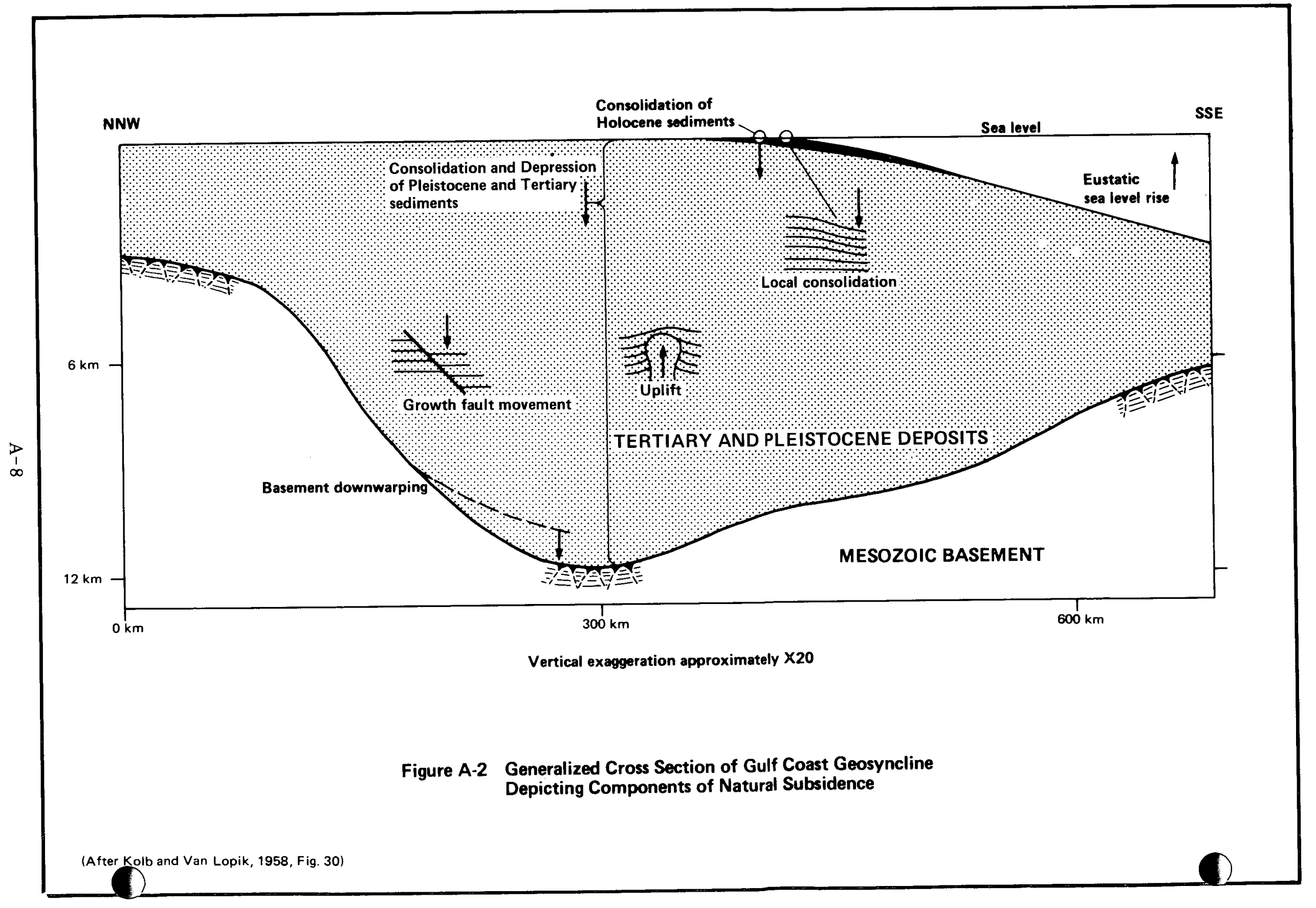




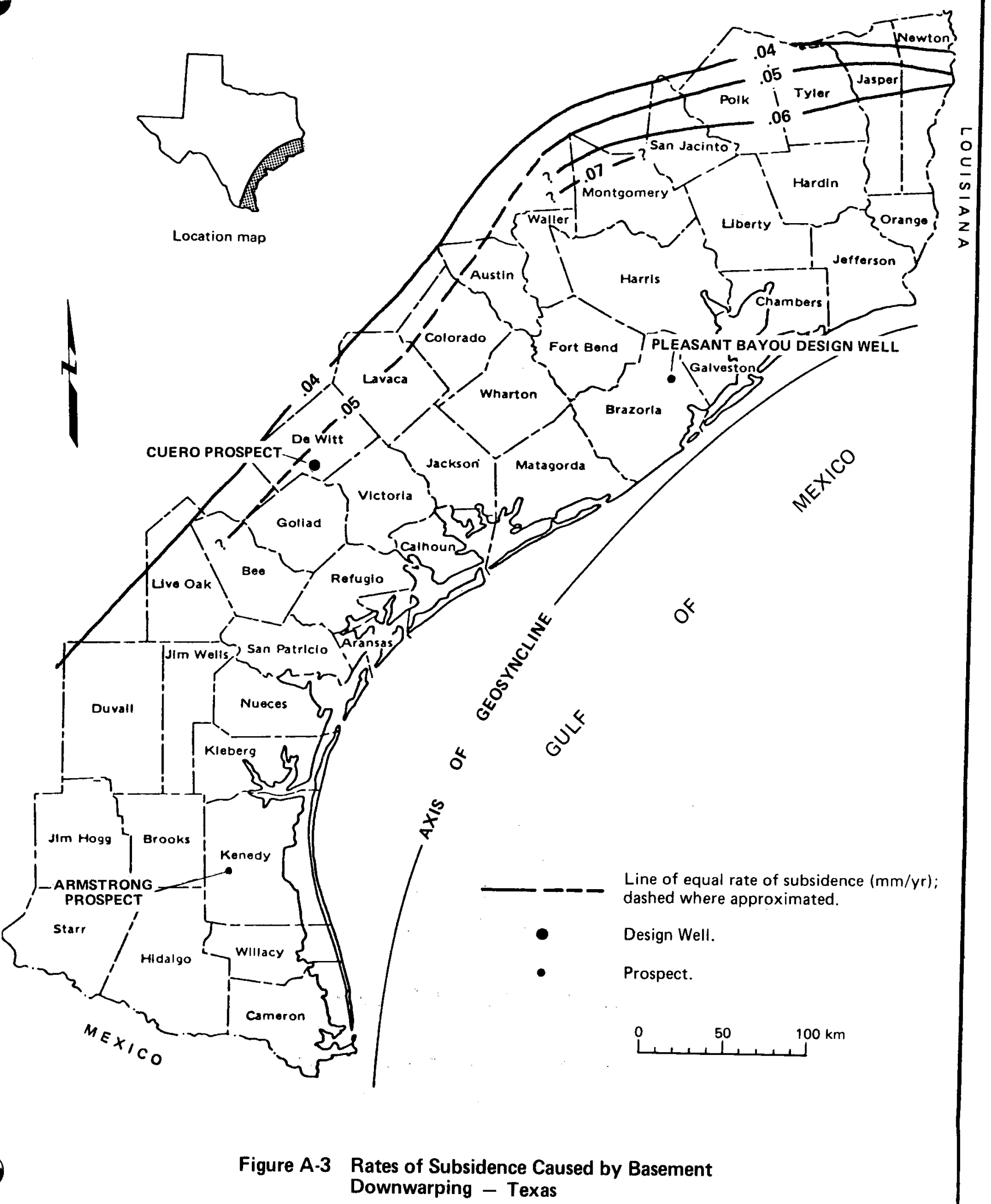

Data derived from cross sections in Bebout and others,

1976 and Baker, 1978. 
commun:, 1982). Rates for Louisiana shown in Figure A-4 do not include the effects of fault movement.

Although basement downwarping is a highly significant process over long spans of geologic time, it is overshadowed by subsidence caused by consolidation of Holocene deposits during shorter periods of time (Morgan, 1967, p. 116).

\section{B. Movement of Growth Faults}

In the Gulf Coast, most faults parallel the coast and are downdropped gulf ward (Figure A-5). Movement along these faults was activated by the weight of deltaic and shoreline sands and muds prograding onto the soft, unstable basinal mud, resulting in a landslide-like movement of the deposits along slip planes (Figure $\mathrm{A}-6$ ).

The inclusion of faults on the geologic cross sections of western Louisiana allows separation of growth fault movement from total subsidence (Figure A-7). From the magnitude of fault displacements, it was found that subsidence due to fault activity is on the order of at least $0.2 \mathrm{~mm} / \mathrm{yr}$ near the coast, decreasing landwards to zero at the edge of the zone of faulting. During periods of high or low seismic activity, the subsidence rate probably has fluctuated from this average rate. However, microseismic monitoring by Teledyne-Geotech (Mauk and others, 1981 , p. 106) shows that seismic events greater than magnitude 1.5 did not occur at the Pleasant Bayou and Parcperdue sites over a recent two-year period and F. J. Mauk (personal commun., 1981) does not expect seismic events of magnitude greater than 2 to occur in the Gulf Coast. This indicates that individual movements on the faults may be small and that associated subsidence rates may not be significantly greater than the average rates reported above.

\section{Consolidation and Depression of Pleistocene and Tertiary Sediments}

Consolidation and depression of Pleistocene and Tertiary sediments in the Gulf Coast geosyncline accounts for a considerable percentage of natural subsidence, especially in Louisiana. Except for relatively brief periods of erosion, deposition has been continuous and the sediments constantly adjust themselves to the newly acquired loads. A mechanism which may have produced some of the 


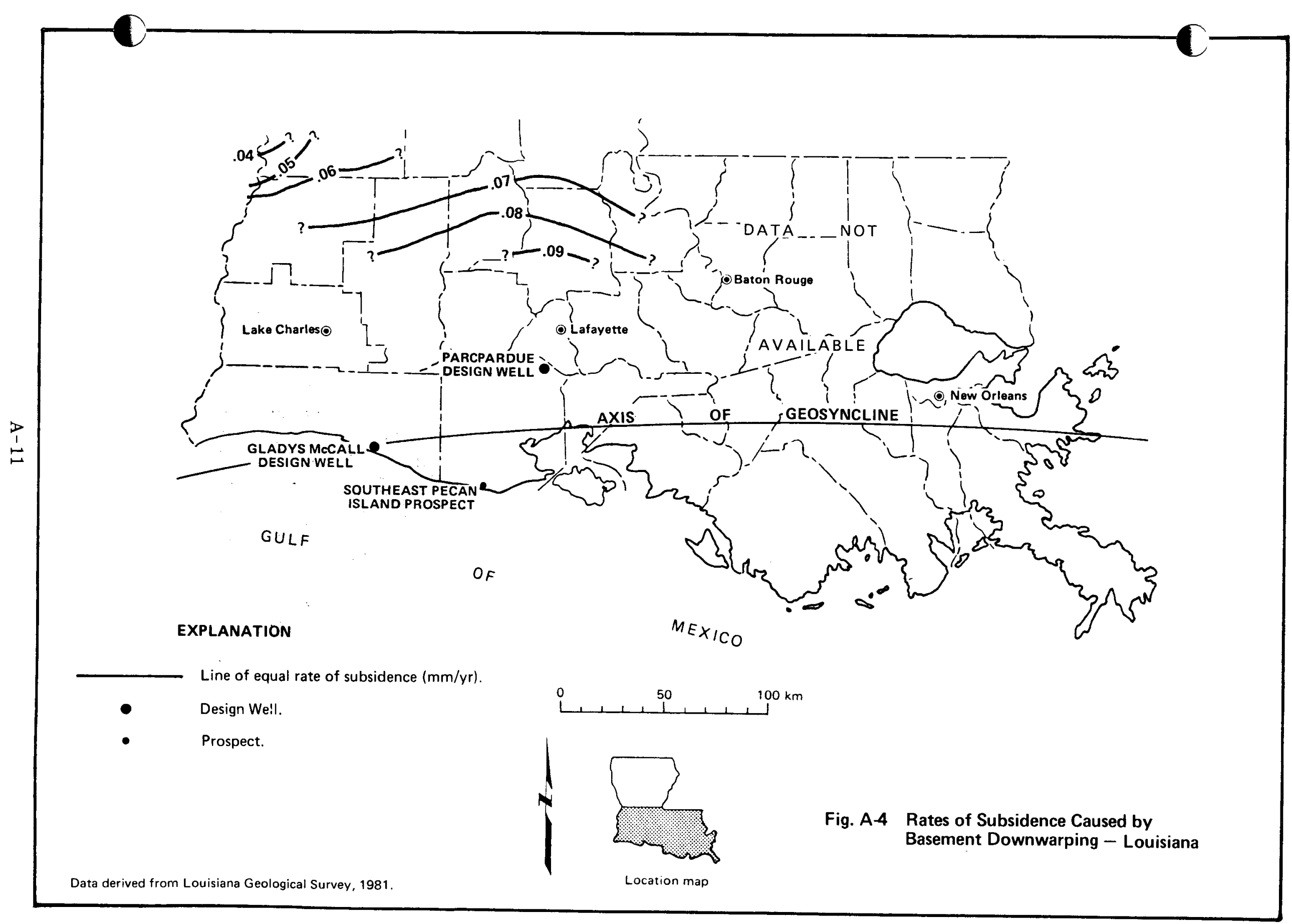




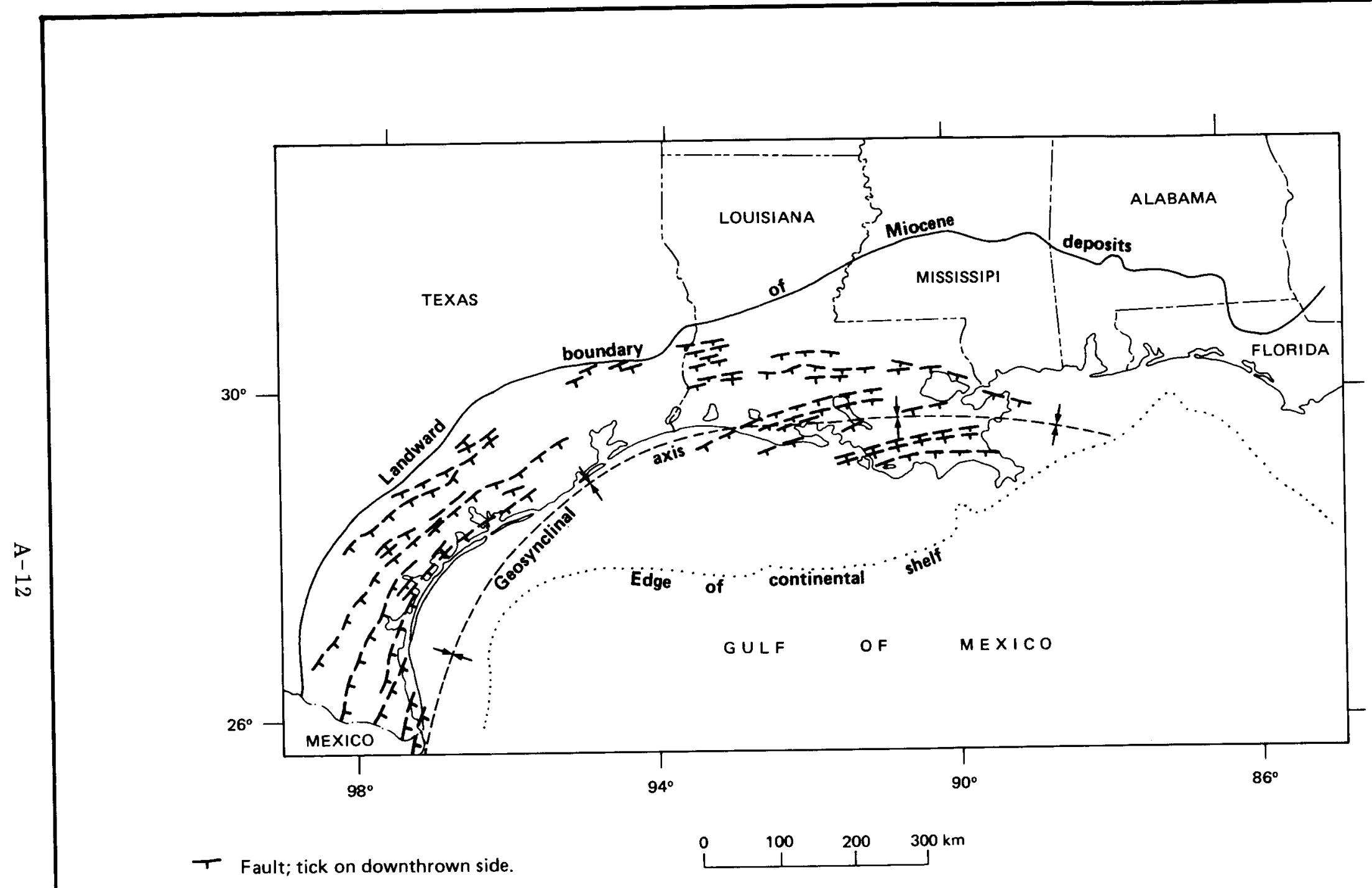

Figure A-5 Principle Regional Faults and Landward Northern Boundary of Miocene Deposits in the Gulf Coast

Geosyncline 


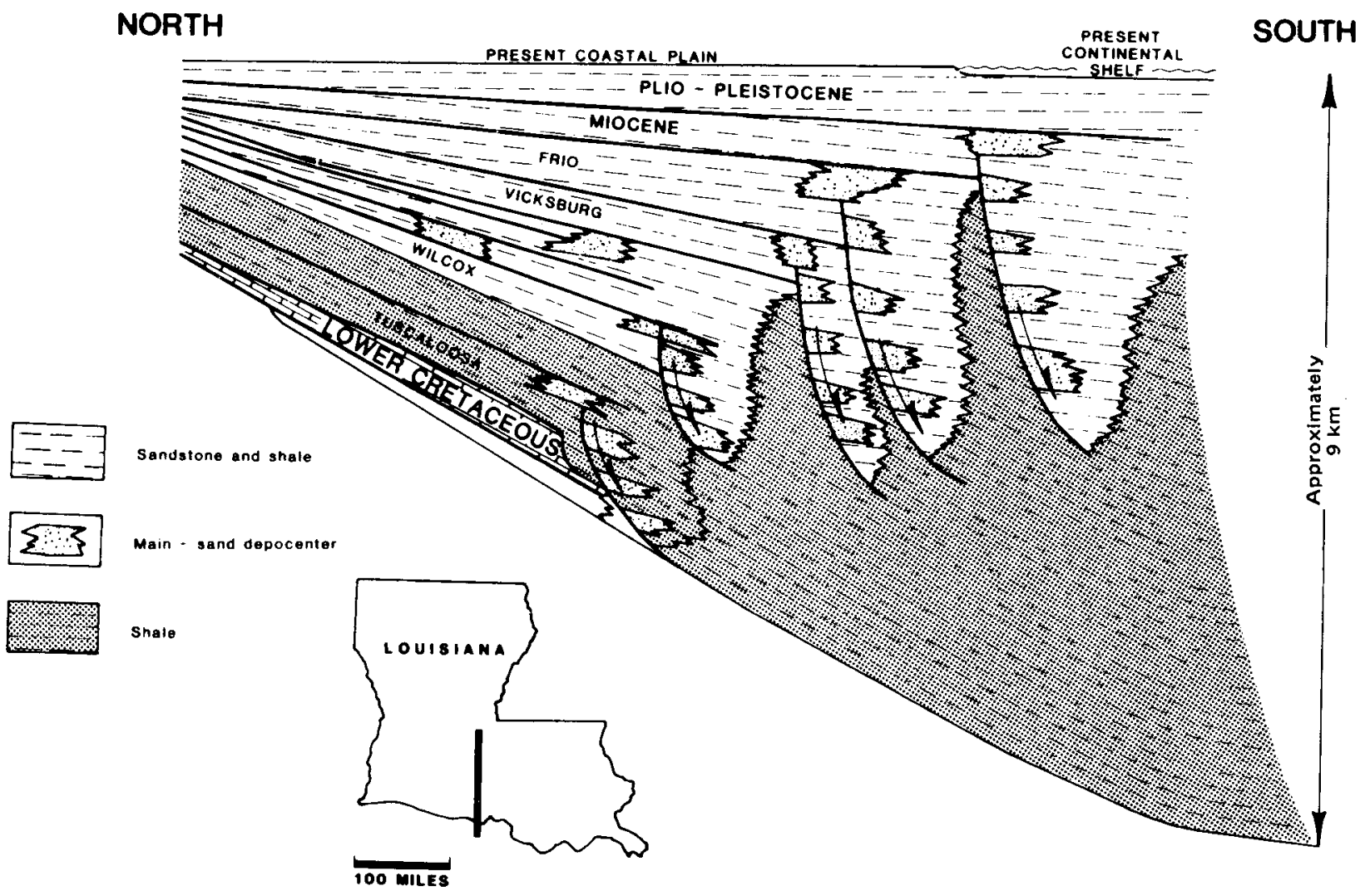

Figure A-6 Diagrammatic Cross Section Across the Gulf Coast Geosyncline

(From Bebout and Gutierrez, 1981, Fig. 4) 


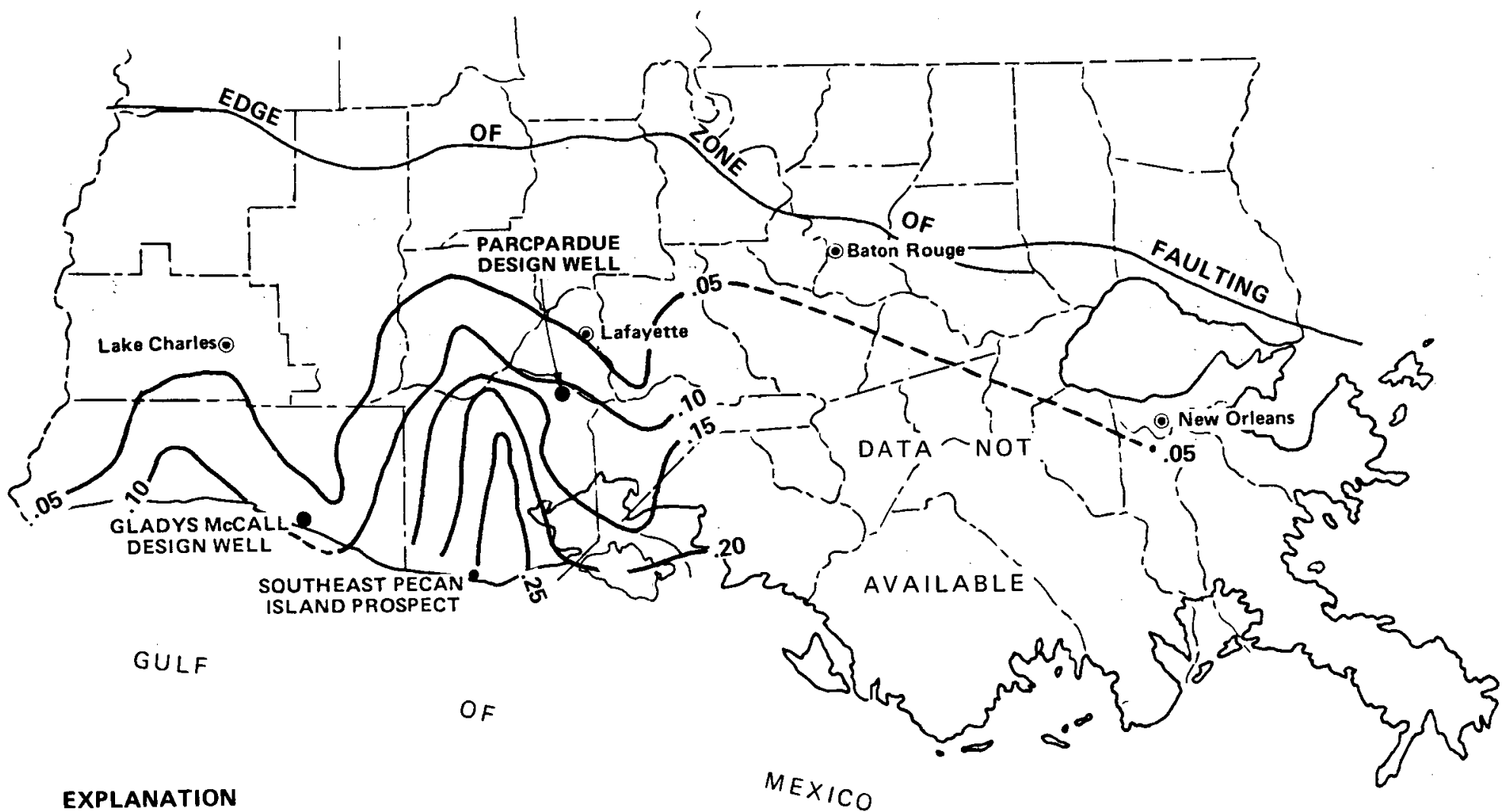

Line of equal rate of subsidence $(\mathrm{mm} / \mathrm{yr})$; dashed where approximated.
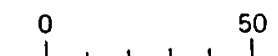

$100 \mathrm{~km}$

- Design Well.

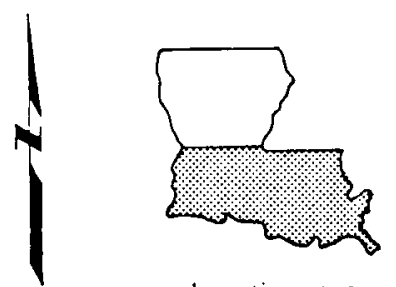

Data derived from Saucier, 1963 and Louisiana Geological Survey, 1981.

Fig. A-7 Rates of Subsidence Caused by Fault Movements - Louisiana 
most rapid consolidation of these sediments is the lowering of sea level during the Pleistocene (Kolb and Van Lopik, 1958, p. 98-99). With a sea level decline of approximately 120 meters, the uppermost sediments were drained and then consolidated at a greater-than-average rate.

The great weight of Holocene sediments deposited on top of the Pleistocene and Tertiary deposits has caused local depression of the Pleistocene surface in the area of the Mississippi delta. A reconstruction of the Pleistocene surface prior to erosion (Fisk and McFarlan, 1955) shows the Pleistocene surface to be bowed downward in an east-west trending, scoop-shaped depression beneath the Mississippi delta lobes. Part of this downwarp is attributable to growth fault movements. Assuming that this downwarp occurred over a span of approximately 45,000 years, that is, since the beginning of the last major lowering of sea level, rates of downwarp can be calculated and are shown in Figure A-8.

\section{Consolidation of Holocene Deposits}

Subsidence of sediments deposited during the Holocene (past 10,000 years or so) is most pronounced in areas of active deposition, such as deltas. The location of the major deltas and associated river systems has shifted throughout geologic time. Major active deposition in Texas ceased in the Early Tertiary when deposition shifted toward Louisiana (Figure A-9). Therefore, significant subsidence attributed to consolidation of Holocene deposits in Texas is considered negligible. In the Mississippi delta region of southeastern Louisiana, however, a great proportion of subsidence results from consolidation of Holocene deposits.

The process of consolidation of Holocene deposits in Louisiana is amply described by Kolb and Van Lopik (1958) and Morgan (1972). Their discussions are summarized in the following three paragraphs.

The Mississippi delta is made up of several individual overlapping lobes which formed during the past $\mathbf{5 0 0 0}$ years. The prograding lobes caused accumulation of a seaward-thickening wedge of unconsolidated sediment varying in thickness from around ten meters in the vicinity of the chenier plain to around 250 meters at the modern delta. The modern deltaic deposits are thicker than the older deposits. This is because the Mississippi delta has prograded to a position relatively close to 


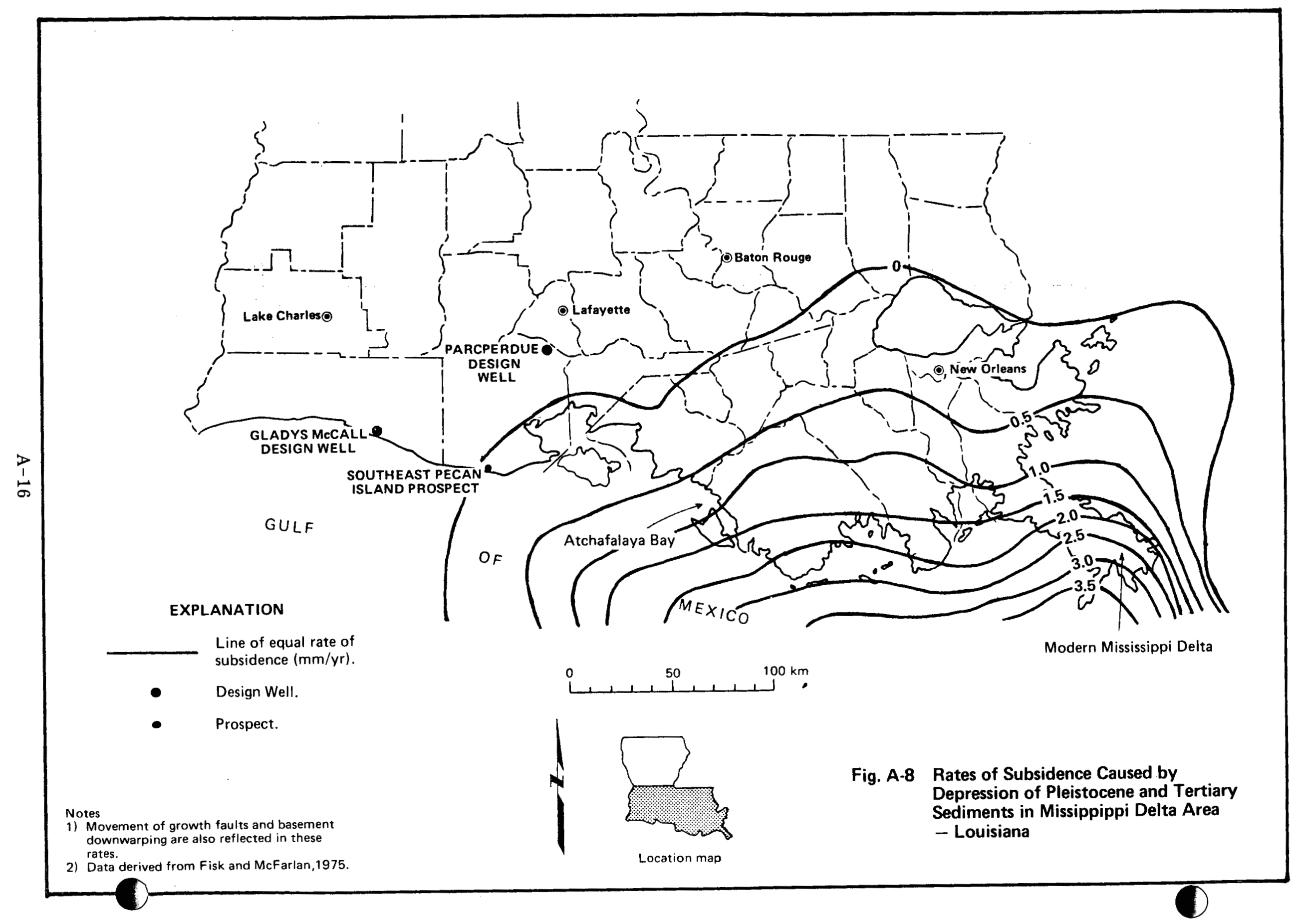




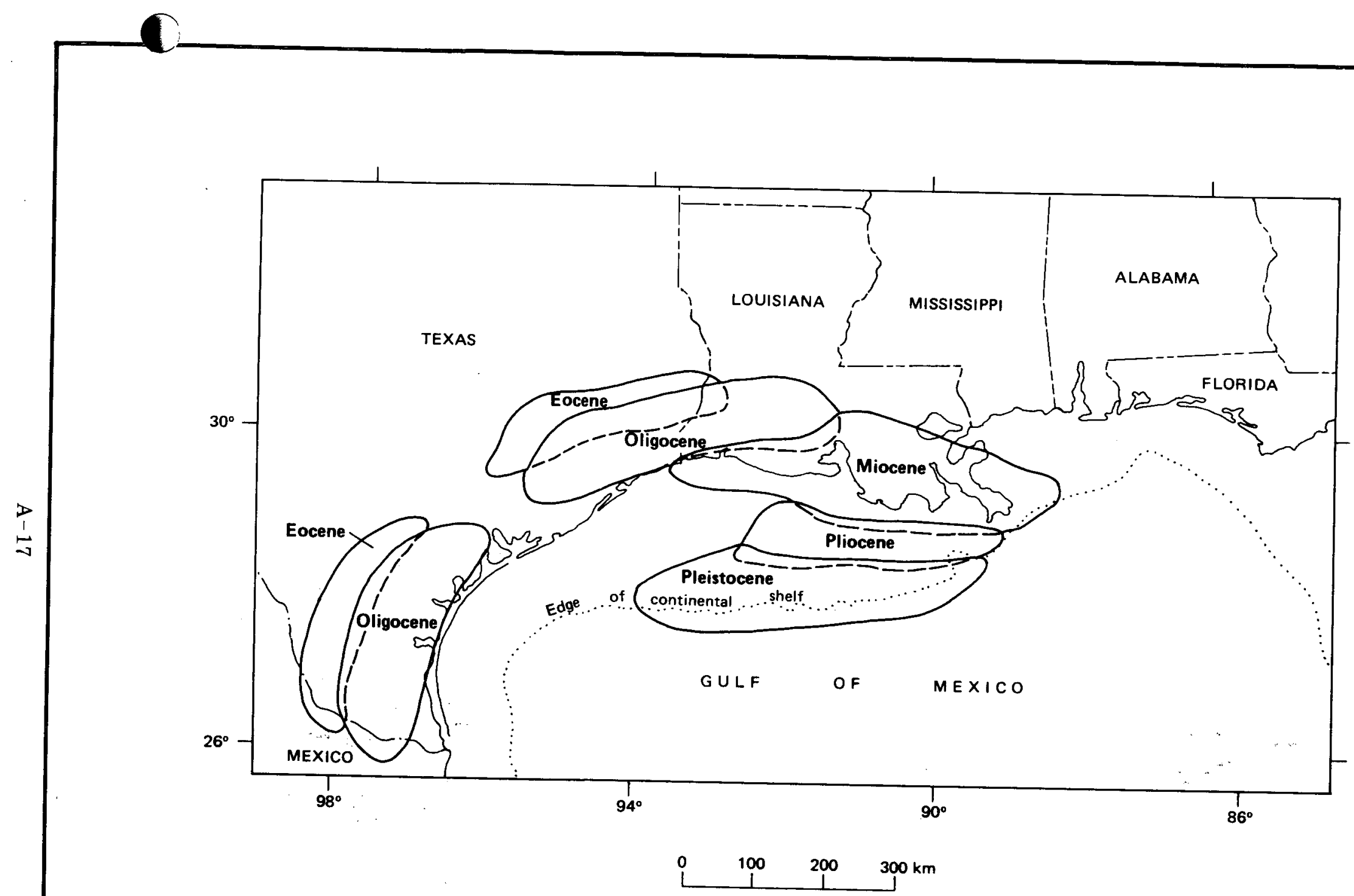

Figure A-9 Sites of Major Cenozoic Deltaic Sedimentation Along the Northern Gulf of Mexico 
the continental shelf edge where a significant part of the river's sedimentary load is being carried into the deep Gulf basin. Consequently, the modern delta lobe is a deep water accumulation in comparison to the older shallow water delta lobes. Thicker deltaic deposits associated with the modern delta have resulted in greater sediment consolidation and correspondingly more rapid subsidence rates.

Sediment consolidation begins contemporaneously with deposition. Upon abandonment of a delta lobe, however, deposition stops and subsidence of the deltaic mass continues at a gradually decreasing rate. Other factors being equal, a recently abandoned delta will subside more rapidly than a delta abandoned a thousand years previously. Consolidation curves indicate that these rapidly deposited clayey delta lobes should take thousands of years to consolidate normally. With the exception of the Atchafalaya and modern Mississippi deltas, all of the delta lobes are in various phases of abandonment or destruction. Consequently, the delta region is subsiding at rates which depend upon the length of time since river abandonment and the thickness of the deltaic lobes. This explains, to an extent, the high subsidence rates within the modern Mississippi delta and the developing Atchafalaya delta.

Once a delta lobe becomes normally consolidated, subsidence due to further consolidation of Holocene sediments should be minor. Further regional subsidence can be attributed to basement downwarping, fault movement, consolidation of Pleistocene and Tertiary sediments, and eustatic sea level rise.

Radiocarbon age determinations made on peats by Frazier (1967) and Saucier (1963) have been used to compute subsidence rates for the Mississippi delta lobes. Assuming that the peats were formed at sea level and that sea level has remained constant, the depth of the peat below today's sea level, divided by the radiocarbon age of the peat, gives the rate of subsidence. These rates are shown on Figure A10. Although these subsidence rates are caused mainly by consolidation of Holocene deposits, the effects of other subsidence processes are also reflected.

Subsidence rates, based on several types of evidence, have been estimated by other investigators for the Atchafalaya and modern Mississippi deltas (Figure A-10). Hicks (1972) and Swanson and Thurlow (1973) report subsidence rates of 13 $\mathrm{mm} / \mathrm{yr}$ and $9.8 \mathrm{~mm} / \mathrm{yr}$ for the Atchafalaya Bay area in recent times. Rates of 


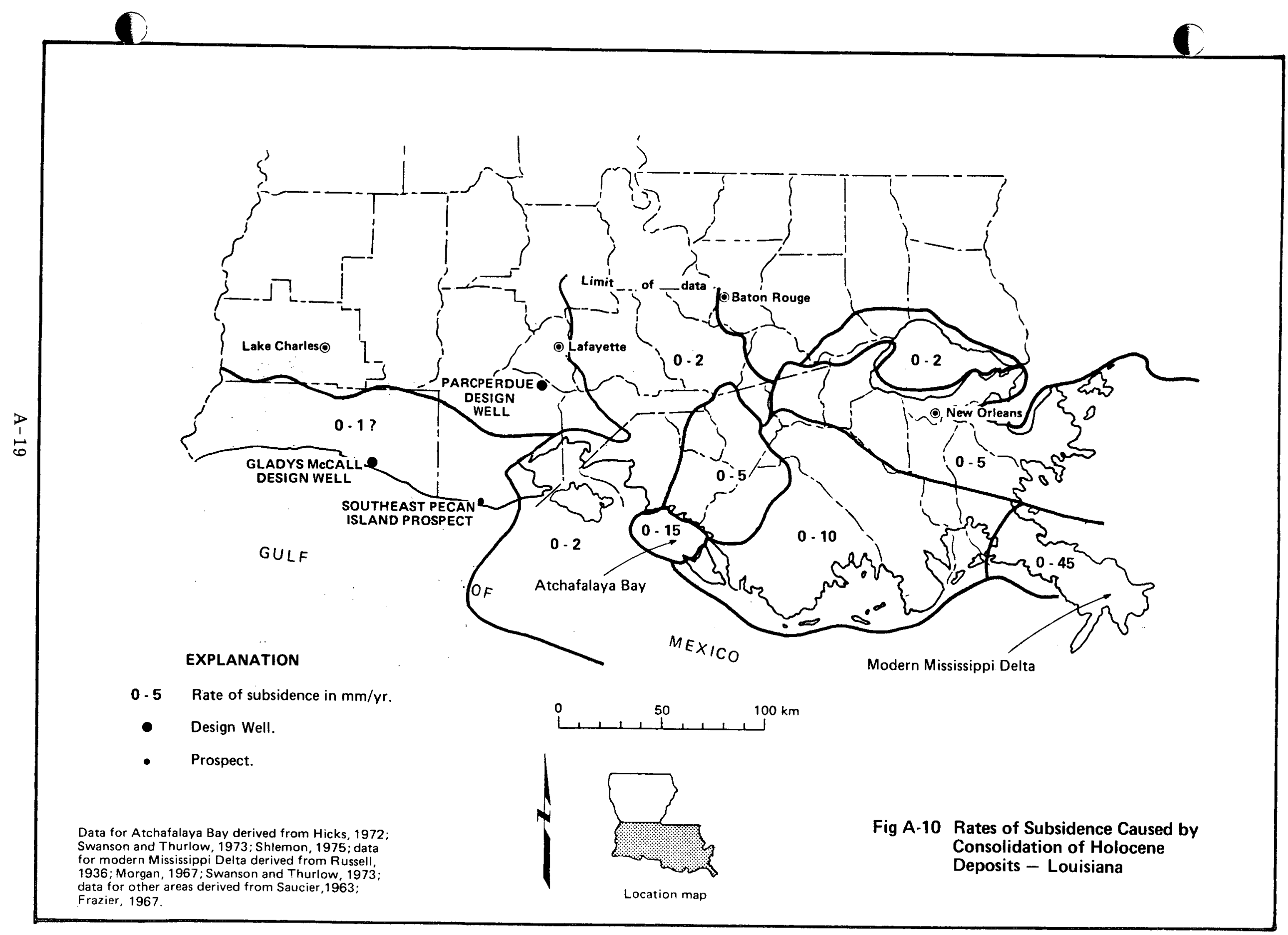


subsidence may increase in the Atchafalaya Bay in the future (Shlemon, 1975, p. 216) due to the increased amount of sediments being deposited there by the Atchafalaya River. This river now diverts a third of the flow of the Mississippi River and deposits $40 \%$ of its sediment on the growing Atchafalaya Delta (J. J. Wells, Louisiana State University, Coastal Studies Institute, personal commun., 1982). Subsidence rates up to about $50 \mathrm{~mm} / \mathrm{yr}$ have been reported in the modern Mississippi delta (Russell, 1936; Morgan, 1967; Swanson and Thurlow, 1973). Again, these high rates are mostly due to consolidation of Holocene deposits, but the effects of other natural subsidence processes are also incorporated. Eustatic sea level rise is not reflected in the rates quoted by Russell, Morgan, and Swanson and Thurlow.

Subsidence caused by consolidation of Holocene sediments is also prevalent in the chenier plain in southwest Louisiana and southeast Texas (Van Sickle and Groat, 1981). However, published subsidence rates in the vicinity of the chenier plain are available for only a few sites and represent total background subsidence and not just consolidation of Holocene sediments. Background rates were measured at the Sweet Lake and Parcperdue Design Well sites by the Louisiana Geological Survey in cooperation with Louisiana State University. Maximum subsidence rates at these locations were $4.2 \mathrm{~mm} / \mathrm{yr}$ and $3.3 \mathrm{~mm} / \mathrm{yr}$, respectively, between 1968 and 1980 (Van Sickle and Grout, 1981). Swanson and Thurlow (1973) report a subsidence rate of $13 \mathrm{~mm} / \mathrm{yr}$ for extreme southwestern Louisiana at Sabine Pass.

Using the available data, the percentage of these subsidence rates (calculated for the delta lobes and measured in the marginal delta) that can be attributed solely to consolidation of Holocene sediments cannot be determined.

\section{E. Eustatic Sea Level Rise}

Eustatic rise of sea level, caused by the melting of glaciers worldwide, is generally thought to be a current phenomenon (Curray, 1960; Shepard, 1960; Van Sickle and Groat, 1981). At present, the rate of this rise seems to be about 1 $\mathrm{mm} / \mathrm{yr}$ (Kolb and Van Lopik, 1958, p. 96; C. G. Groat, personal commun., 1982). The rise has been noted only in the last 40 years or so, and some attribute it to melting of the glaciers in response to a worldwide climatic change. If the trend reverses itself in the near future, the resultant sea level fluctuation will be minor 
and could possibly be typical of minor variations which undoubtedly occurred during the last 3000 to 5000 years (Saucier, 1963, p. 16).

Shepard, a protagonist of sea level rise, cautions that because the rate of sea level rise is so low, the rise may not really exist. Other authors (Fisk, 1960; Coleman and Smith, 1964) claim that sea level has been virtually constant along the Gulf Coast during the past 5,000 years or so, indicating that there is no present significant sea level rise. However, their data come from unstable areas, such as the Mississippi delta area, and so their conclusions are open to question.

\section{F. Local Consolidation}

Local subsidence is much more variable in amount and area than regional subsidence. Minor landforms, such as natural levees, experience a certain amount of internal consolidation while slowly depressing the underlying deposits because of their weight. Where this occurs, the Holocene sediments in that area are depressed considerably more than the deposits over a more regional area. Because of this phenomenon, the location of subsidence measurements is important. For example, a subsidence measurement taken on top of a levee could reflect subsidence due to consolidation within the levee and local consolidation of sediments beneath the levee, as well as more regional types of subsidence. Some subsidence in New Orleans is caused by consolidation of the natural levees on which the city was founded. Because of the difficulties in showing the effects of this local process on a regional scale, local consolidation has not been mapped.

\section{G. Uplift}

Diapiric movement of salt domes locally offsets total subsidence. An uplift rate of $0.3 \mathrm{~mm} / \mathrm{yr}$ has been suggested by Martinez and others (1975, p. 33). Groat (personal commun., 1982) indicates that diapiric movement may be occurring at a rate of a few millimeters per year. Uplift near the Sweet Lake Design Well may well have been caused by movement of the Sweet Lake salt dome located 8 kilometers to the southeast (Van Sickle and Groat, 1981, p. 326). The upward movement of salt domes may also offset total subsidence on a more regional scale. Groat (personal commun., 1982) believes that some anomalous areas of low subsidence may be related to diapiric movement of groups of salt domes. On a 
very local basis, the rise of mudlumps causes uplift within the active Mississippi delta. Because of their local nature, the rates of uplift of these local features have not been mapped. 


\section{MAN-INDUCED SUBSIDENCE PROCESSES}

Man-induced subsidence, like natural subsidence, is caused or affected by several processes. Figure A-11 depicts a generalized cross section of the Gulf Coast geosyncline and displays the following components of man-induced subsidence: groundwater withdrawal, oil and gas production, solution mining, peat deflation, local consolidation, and hydrofracturing. Subsidence rates caused by these man-induced processes are shown on Figures A-12 through A-17. Each process is discussed separately in the succeeding sections.

In the Texas coastal region, man-induced subsidence is primarily caused by the withdrawal of groundwater, oil, and gas. Locally, subsidence also results from sulfur mining.

In Louisiana, man-induced subsidence is not of the same magnitude as that in Texas. A. N. Turcan (personal commun., 1981), director of the Capital-Area Groundwater Conservation Commission in Baton Rouge, points out two reasons why this may be so. First, the marginal delta, or chenier plain, of Louisiana has not been developed as much as the Texas coastal area, possibly owing to the marshy conditions and threat of hurricane. Less development in the coastal zone means less of a demand for groundwater and less groundwater development-induced subsidence. A second reason may involve the spacing of oil wells. In the late 1930's, stringent laws were passed concerning the unitization of land. These laws regulate the spacing of wells, so that Louisiana oil wells are not so clustered as are the Texas wells. Nevertheless, Louisiana has experienced some man-induced subsidence, mostly caused by groundwater withdrawal and peat deflation.

\section{A. Groundwater Withdrawal}

The withdrawal of groundwater from an artesian aquifer results in the drop of the water level and the decrease of pore pressure. For sands, adjustment to the pore pressure change is immediate. For clays and silts, the adjustment is slow. Therefore, a hydraulic gradient is created between sands and clays which causes 


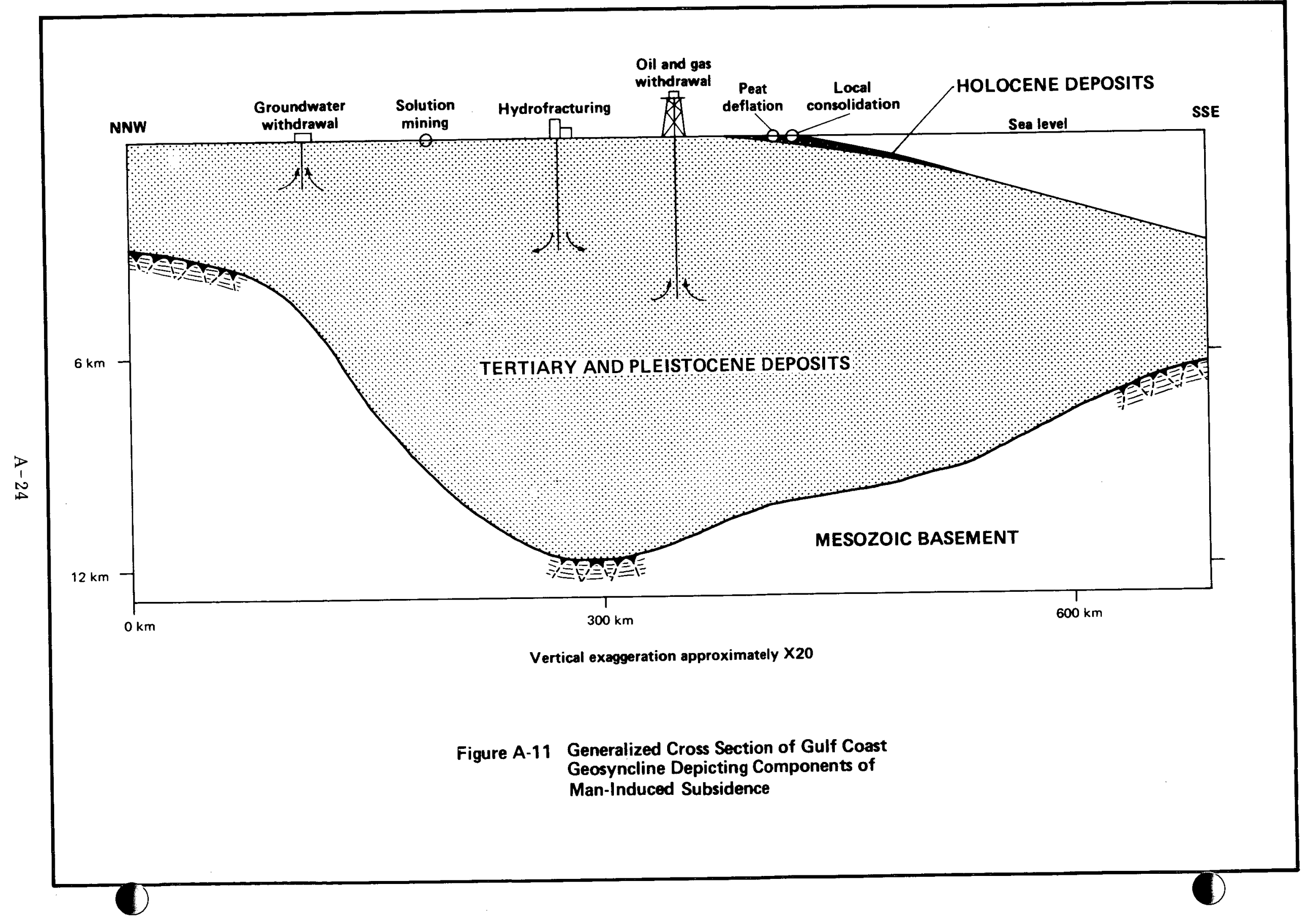


water to flow from the clays into the sands. As the water leaves the clays, the clays are depressurized and the weight of the overlying sediments causes the clays to compact. This compaction is transmitted to the ground surface as subsidence.

The Houston area in Texas is well known for subsidence caused by groundwater withdrawal. Other areas such as Beaumont, Texas and Baton Rouge and New Orleans, Louisiana also suffer from the effects of groundwater development, although not to the same extent as Houston. A discussion of subsidence caused by groundwater development in Texas and Louisiana follows, starting in southern Texas and moving north and east. The majority of the discussion about Texas comes from Ratzlaff (1980).

\section{Texas}

\section{Subregion 1}

It is difficult to determine if subsidence is being caused by man's activities in the area from the Mexican border north through Kenedy and Brooks Counties (Subregion 1 on Figure A-12). Land surface declines have been small, many being within the accuracy for benchmark leveling. If subsidence is now occurring in the areas where repetitive levelings have been made, the rates are very low. In Brooks County, where water levels have declined, no subsidence has been detected because of the lack of repetitive levelings. Because so little measured subsidence has occurred or can be attributed to man's activities in Subregion 1, no map of this area was prepared.

\section{Subregion 2}

Northeastward, in Refugio County (Figure A-13), subsidence occurred at a maximum rate of $8.3 \mathrm{~mm} / \mathrm{yr}$ between 1918 and 1943. From 1943-1951, the rate slowed to $2.9 \mathrm{~mm} / \mathrm{yr}$. Decline of water levels may have caused part of this past subsidence, but, as discussed later in Appendix Section IV.B.1., production of oil and gas in the vicinity was also a contributing factor. 


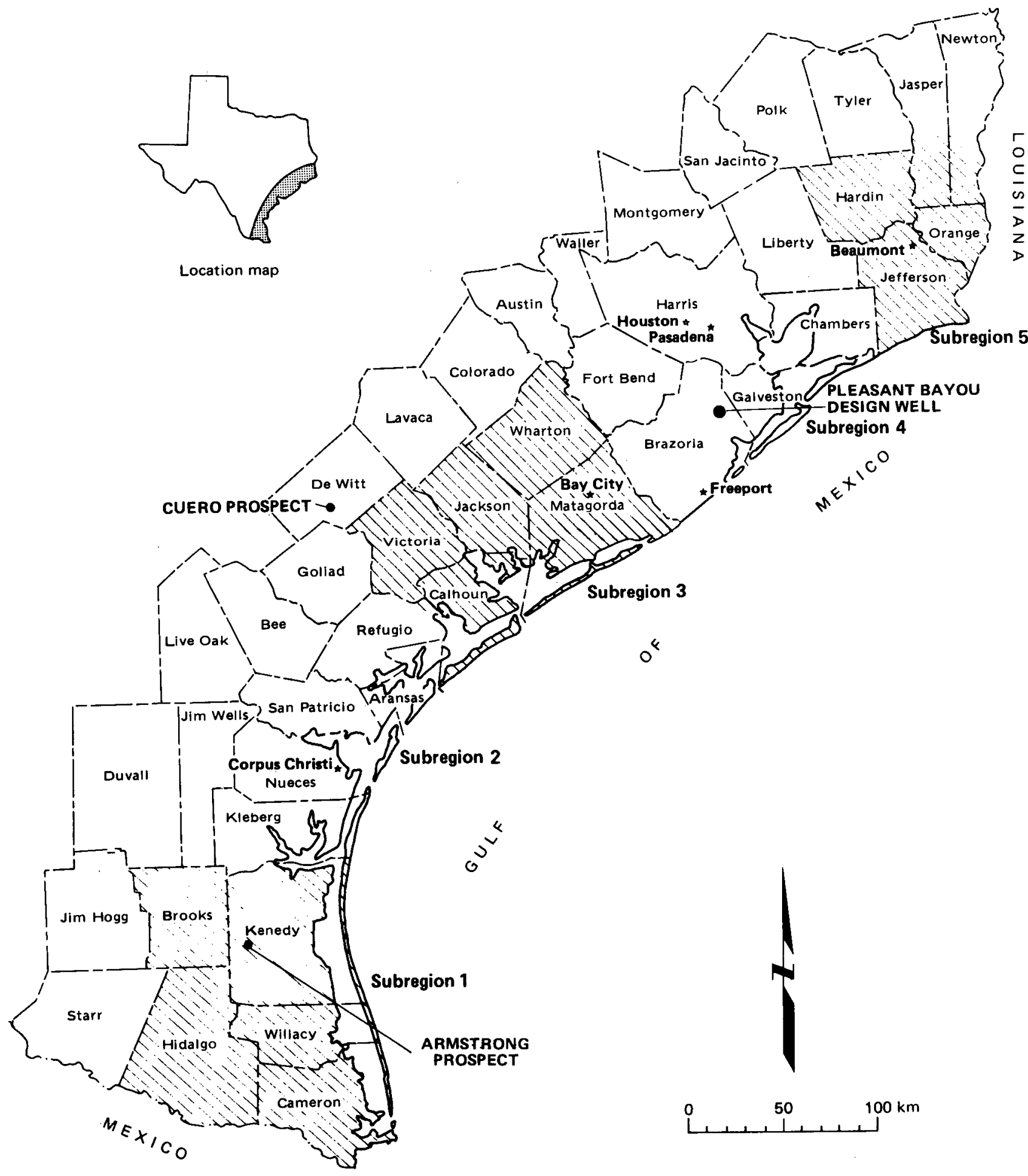

- Design Well.

- Prospect.

Figure A-12 Location of Texas Subregions (see Figures A-13 - A-16)

(After Ratzlaff, 1980, Fig. 1) 


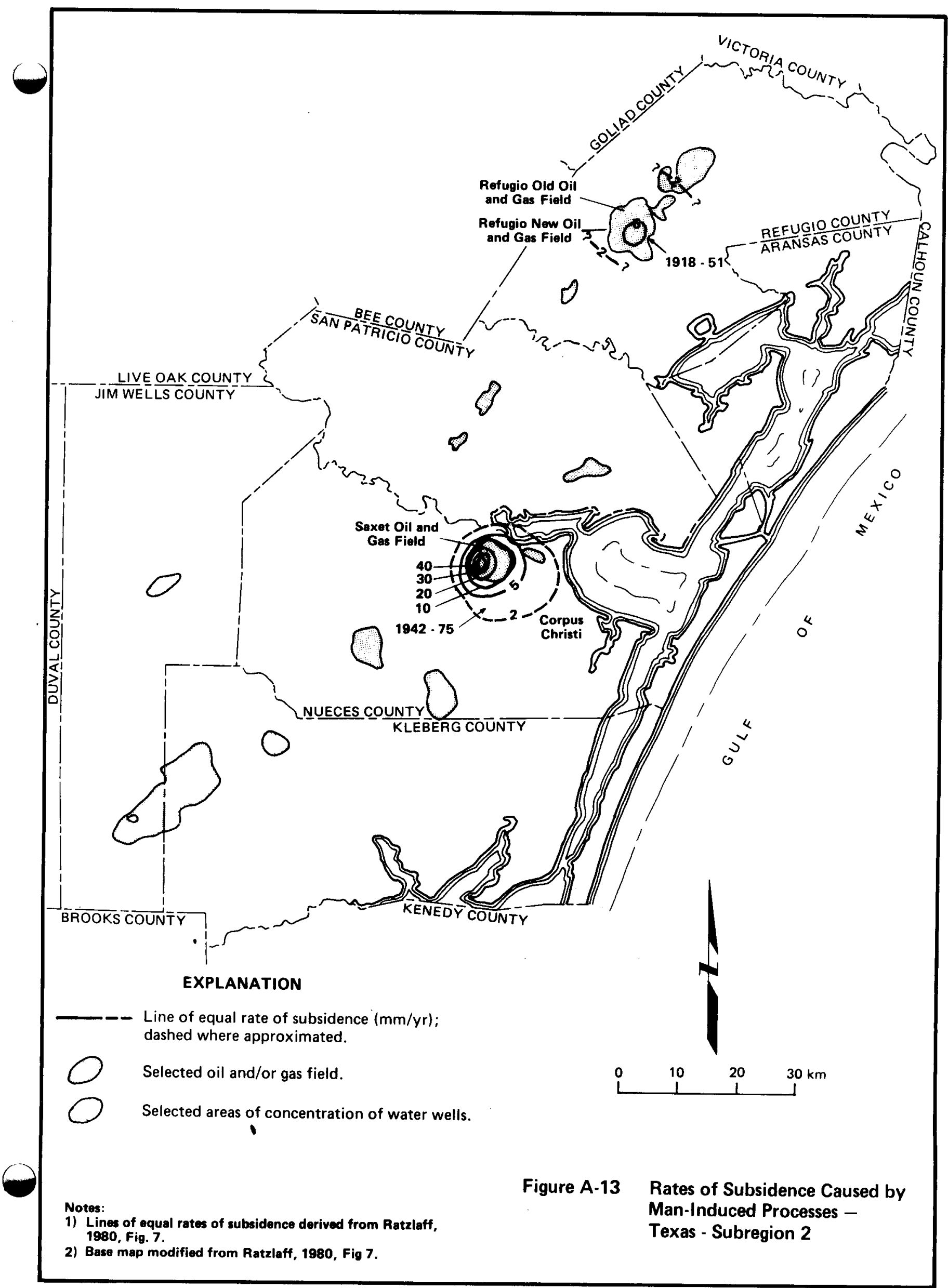




\section{$\underline{\text { Subregion } 3}$}

An area of subsidence extending into Matagorda and Victoria Counties from Jackson County (Figure A-14) was caused principally by an increase in groundwater withdrawals for rice irrigation in the early 1950's. The highest rates over the period of 1918-1973 were on the order of $11 \mathrm{~mm} / \mathrm{yr}$ and occurred just west of the Matagorda-Jackson line. More representative rates in this area were around $3 \mathrm{~mm} / \mathrm{yr}$.

Subsidence at Bay City probably results from the withdrawal of both groundwater and the production of oil and gas. However, subsidence on the order of $5 \mathrm{~mm} / \mathrm{yr}$ in eastern Matagorda County in the vicinity of the Old Ocean Oil and Gas Field is probably due to withdrawal of groundwater rather than from oil or gas production.

\section{$\underline{\text { Subregion } 4}$}

Subsidence near Freeport in Brazoria County (Figure A-15) has been caused by groundwater withdrawals from shallow aquifers for municipal supply and industrial use. Although extensometers show a recent rise of the land surface near Freeport, Gabrysch (personal commun., 1981) believes that the "rise" was caused by problems in data reduction and that the land is actually still subsiding.

In the Chocolate Bayou area, Grimsrud and others (1978, p. V-74) and Earth Sciences Associates (1979) have determined that groundwater development accounts for at least a third of the observed 0.55 meters of maximum subsidence. However, petroleum production has probably been the largest contributor to subsidence in this area. See Section IV.B.1. for a discussion of subsidence rates in the Chocolate Bayou area.

Benchmark releveling near the Pleasant Bayou Design Well indicates total background subsidence of between 5 and $6 \mathrm{~mm} / \mathrm{yr}$ between 1957 and 1978 (Gustavson, 1979, p. 7). Gabrysch (personal commun., 1981) believes that background subsidence near Pleasant Bayou may decrease to zero in the next few years. 


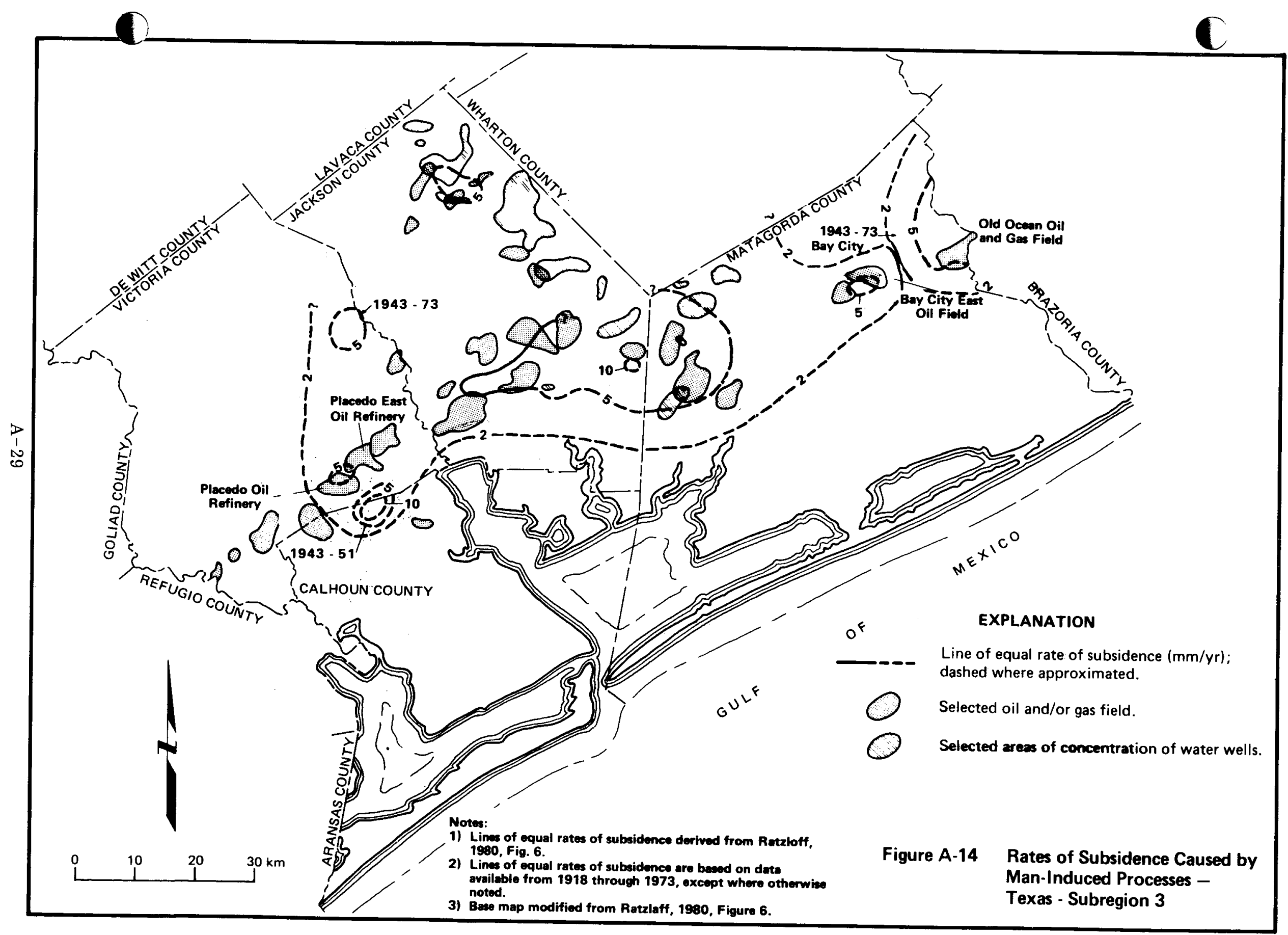




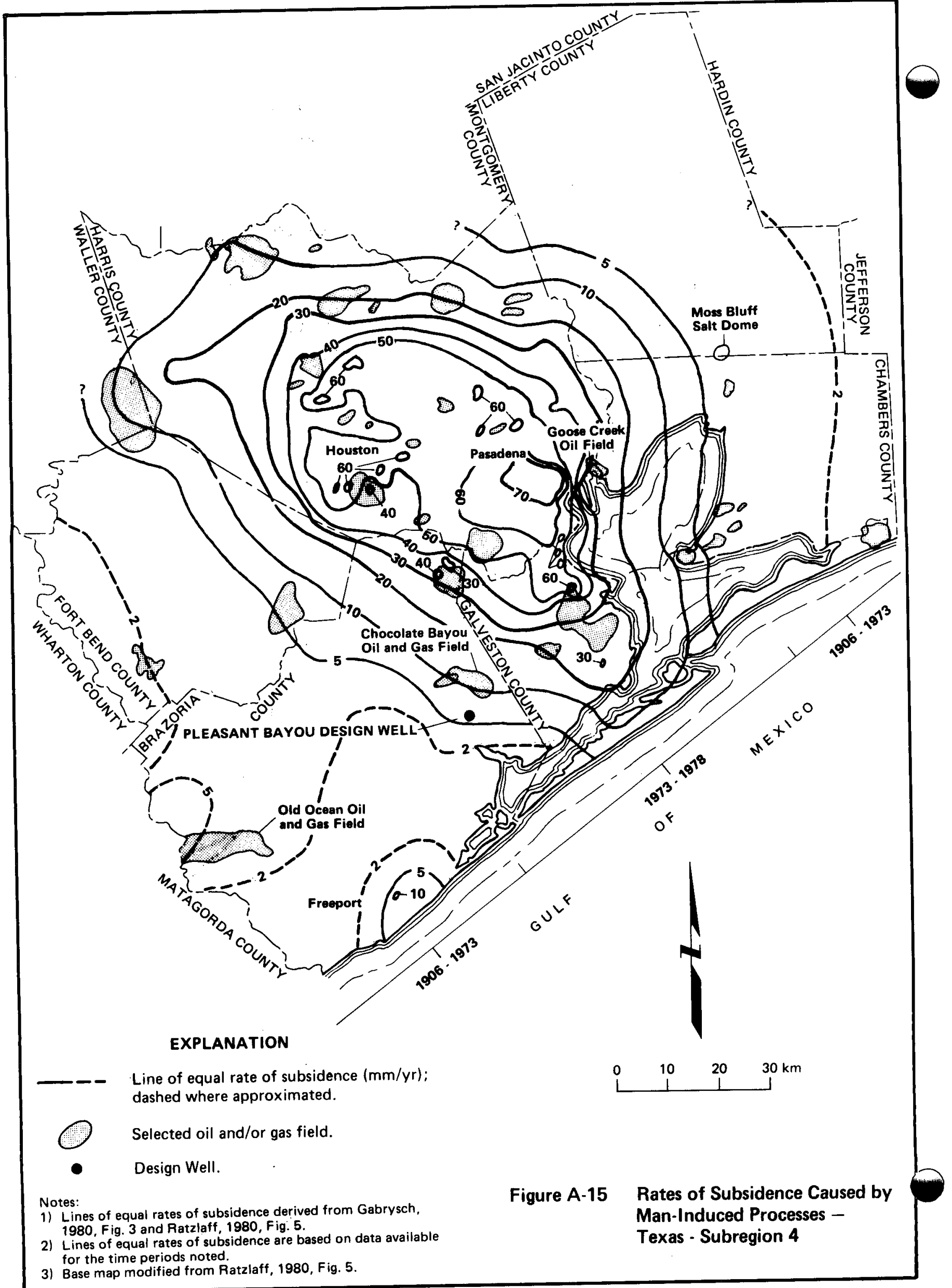


The highest rates of subsidence in the Texas-Louisiana Gulf Coast occur in the Houston-Pasadena area where rates during 1973-1978 exceeded 80 $\mathrm{mm} / \mathrm{yr}$. This area of great subsidence has been well documented by Gabrysch (1969, 1972, 1977, 1980) and Gabrysch and Bonnet (1975). Although oil and gas production may have contributed locally to the high subsidence rate, the control necessary to define the amount is not available. Some slowdown of the high subsidence rates is in sight, however. Gabrysch (personal commun., 1981) indicates that groundwater usage in southeast Harris and Galveston Counties is expected to decrease in the next five years. Also, Pasadena does not seem to have subsided further since 1978. However, Gabrysch also reports that groundwater may be developed in northern Brazoria County within ten years, giving rise to a considerable rate of subsidence $(60-90 \mathrm{~mm} / \mathrm{yr})$. So, although subsidence will continue in the Houston area, the rates, except in Brazoria County, may decrease from what is shown on Figure A-15.

\section{$\underline{\text { Subregion } 5}$}

Northeast of Houston (Figure A-16), several areas are subsiding because of groundwater withdrawals. In northwestern Jefferson County and near, or in, the city of Beaumont, groundwater usage is probably causing subsidence, as well fields are near the subsided areas. The cause of subsidence in two small areas in southeastern Jefferson County is uncertain; undetected water level declines or local consolidation are two possible causes. Subsidence in Orange County is also mainly caused by groundwater withdrawals and occurred at a rate of around 4 $\mathrm{mm} / \mathrm{yr}$ during the period 1918-1973.

\section{Louisiana}

Subsidence caused by groundwater withdrawal has not occurred in Louisiana to the extent that it has in Texas, but some subsidence has occurred near cities along the Mississippi River and in western Louisiana (Figure A-17).

\section{Baton Rouge}

Since 1935, over a foot of subsidence in Baton Rouge has resulted primarily from pumping groundwater for industrial and municipal uses. This 


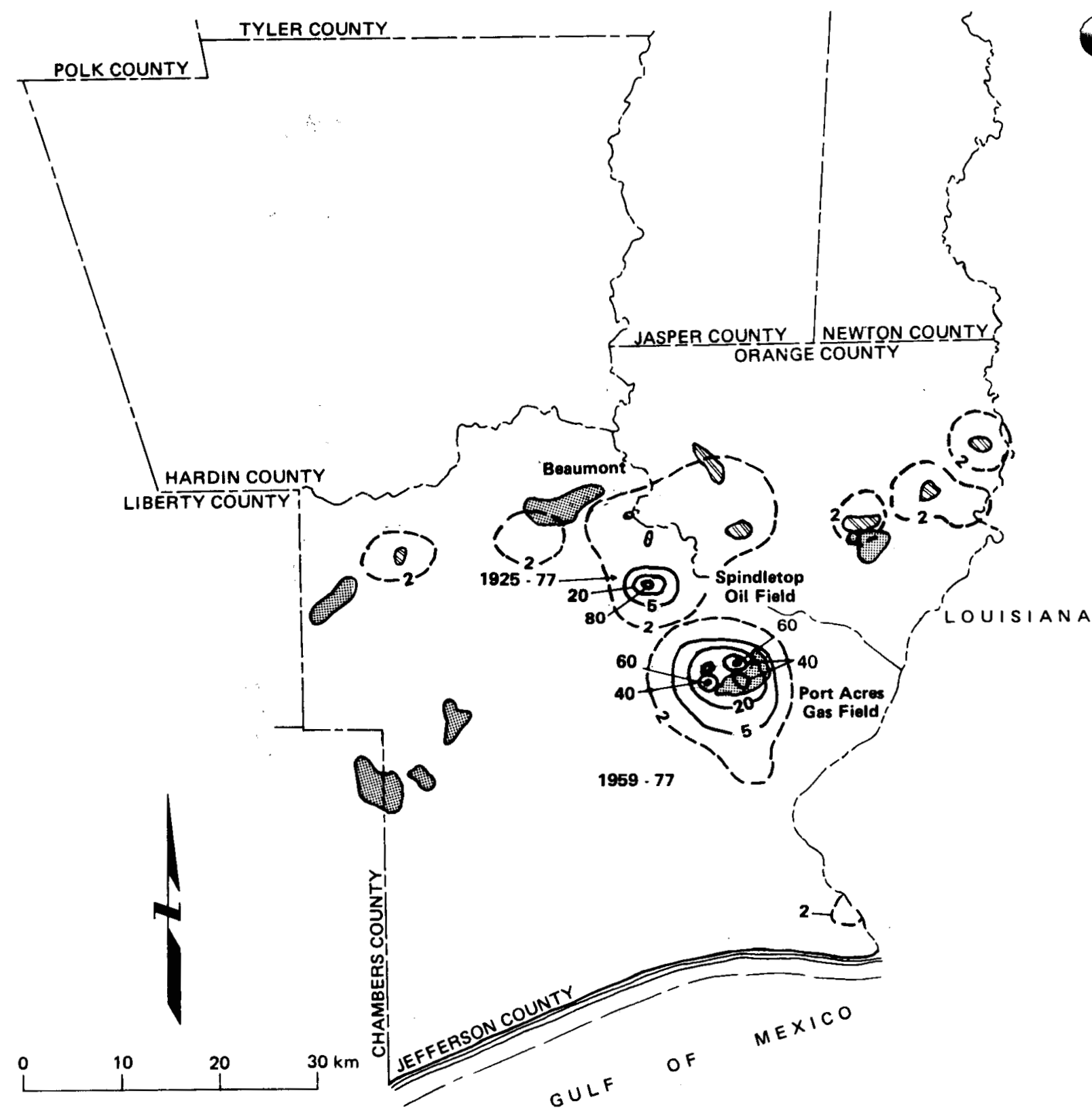

EXPLANATION

Line of equal rate of subsidence $(\mathrm{mm} / \mathrm{yr})$; dashed where approximated.

Selected oil and/or gas field.

Selected areas of concentration of water wells.

Notes:

1) Lines of equal rates of subsidence derived from Ratzlatf, 1880, Fig. 2.

2) Lines of equal rates of subsidence are based on data available from 1918 through 1977, except where otherwise noted.

3) Base map modified from Ratzlaff, 1980, Fig. 2.
Figure A-16

Rates of Subsidence Caused by Man-Induced Processes Texas - Subregion 5 


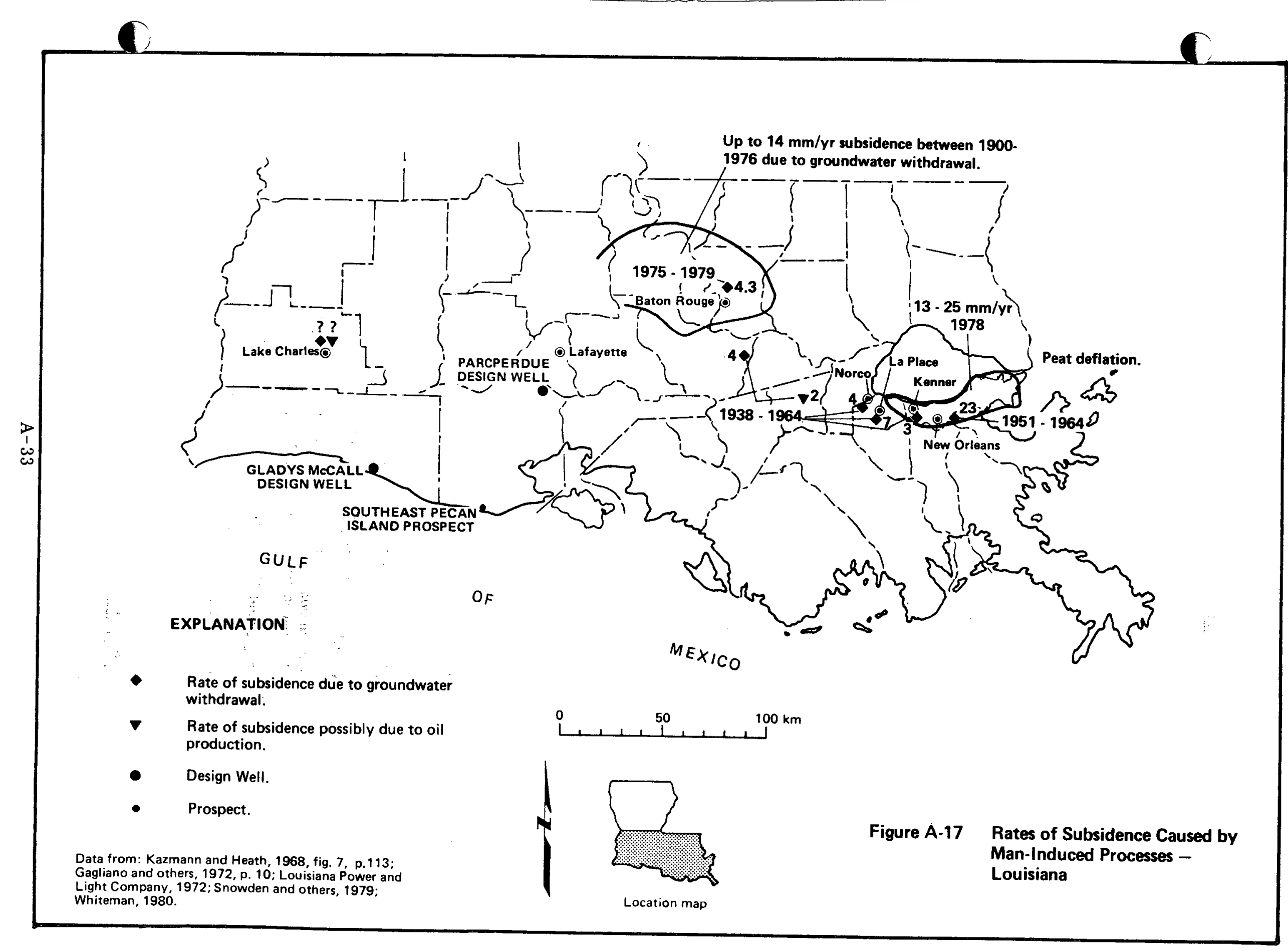


subsidence extends around Baton Rouge mainly to the northwest of the city. Up until 1975, maximum rates of subsidence in the Baton Rouge area were on the order of $14 \mathrm{~mm} / \mathrm{yr}$ (Davis and Rollo, 1969; Kazmann, 1970; Wintz and others, 1970; Smith and Kazmann, 1978). In late 1974 and early 1975, industrial pumping was sharply reduced. : This decrease in industrial pumping has been enough to offset continued increases in pumping for municipal supplies since 1975. Water levels are now higher in most of the major aquifers than they were in the early 1970's (Whiteman, 1980, p. 12) and, during the period of 1975-1979, the maximum subsidence rate decreased to an average of $4.3 \mathrm{~mm} / \mathrm{yr}$. With water levels relatively stable, a good portion of this observed subsidence is probably the result of continued adjustment of pore pressures in the thick clays of the area to water level declines that occurred before 1975 . Whiteman $(1980, p .12)$ predicts for the future:

If water levels stabilize at their present levels, compaction should continue at a gradually decreasing rate for many years until the excess pore pressures dissipate. If water levels resume their declining trend, which seems likely to happen as a result of population growth, even if industrial pumping remains relatively low, the rate of compaction will increase again as water levels fall below their earlier levels.

\section{Along the Mississippi - Baton Rouge to New Orleans}

Use of groundwater south of Baton Rouge is spotty, as most domestic water comes from rivers (C. G. Groat, personal commun., 1982). Nevertheless, several areas along the Mississippi River have experienced subsidence due to groundwater extraction. Just south of Baton Rouge, pumping for industrial purposes caused an average of $4 \mathrm{~mm} / \mathrm{yr}$ of subsidence from 1938-1964. At the LaPlace Community, concentrated groundwater withdrawal caused a local subsidence bowl about a kilometer in radius. From 1938-1964, subsidence here occurred at a rate of about $4 \mathrm{~mm} / \mathrm{yr}$. It is interesting to note, however, that piezometric records of wells in the LaPlace area showed water levels to be generally constant during this same time period. At Norco, benchmark leveling shows an average of $7 \mathrm{~mm} / \mathrm{yr}$ of subsidence caused by groundwater withdrawal for the period 1938-1964. Here also, subsidence was bowl-shaped and about a kilometer in diameter. It was reported that Kenner, Louisiana also experienced about $3 \mathrm{~mm} / \mathrm{yr}$ of subsidence caused by groundwater withdrawals during 1938-1964. (See Louisiana Power and Light Company, 1971, p. Q 2.7-4; 1972, Fig. Q2.45 A-2.) 


\section{$\underline{\text { New Orleans }}$}

Subsidence in, and west of, New Orleans has been attributed to groundwater withdrawals (Kazmann and Heath, 1969). These authors report that a good deal of the subsidence occurred from 1938-1951 at a rate of about $7 \mathrm{~mm} / \mathrm{yr}$. From 1951-1964, the rate increased to over $20 \mathrm{~mm} / \mathrm{yr}$. A. N. Turcan (personal commun., 1981) believes that subsidence in New Orleans cannot be totally caused by groundwater pumping, however, because too small an amount of water is being pumped. Most domestic water is taken from the Mississippi River (C. G. Groat, personal commun., 1982). Turcan reports that the drainage of clays and peats for development purposes has caused much of the subsidence seen in New Orleans (see Section IV.D.).

\section{Western Louisiana}

The Lake Charles area is experiencing man-induced subsidence caused by industrial and agricultural use of groundwater (A. N. Turcan, personal commun., 1981; C. G. Groat, personal commun., 1982), as well as possibly from oil and gas production (A. N. Turcan, personal commun., 1981.) The U.S. Geological Survey (1966) reported $3.3 \mathrm{~mm} / \mathrm{yr}$ of total subsidence in the Lake Charles area from 19181955. A total subsidence rate of $1.7 \mathrm{~mm} / \mathrm{yr}$ over the same time period in the Lafayette area was reported by the same agency (1966). The greater part of the subsidence at Lafayette may be caused by local pumping of groundwater for rice irrigation (C. G. Groat, personal commun., 1982). It should also be noted that Lafayette is more distant from the coastal marshes and associated consolidation of Holocene deposits than is Lake Charles.

\section{B. Oil and Gas Production}

The process by which oil and gas production causes subsidence is similar to that by which groundwater withdrawal causes subsidence. As pore pressure in the reservoir decreases owing to the extraction of oil or gas, increased effective stress causes reservoir compaction, some of which may be translated to the surface, causing land subsidence. 
As in the previous section, the discussion of subsidence caused by oil and gas production will begin in southern Texas and move north and east through Louisiana. Most of the discussion about Texas comes from Ratzlaff (1980).

\section{Texas}

Subsidence in several areas in Texas is attributed to the production of oil and gas and associated groundwater, most noticeably in the Corpus Christi area, the Houston area, and in Jefferson County.

\section{Subregion 1}

Subsidence caused by oil and gas production in Subregion 1 has not been reported.

\section{Subregion 2}

In the western part of Corpus Christi, subsidence averaged $49 \mathrm{~mm} / \mathrm{yr}$ between 1942 and 1975 (Figure A-13). Ratzlaff (1980, p. 13) reports that

The outline of the subsidence bowl, which closely corresponds to the outline of the Saxet Oil and Gas Field; the comparative shallowness of the Saxet field (4,060-8,100 feet or 1,237-2,469 m); and the lack of groundwater withdrawal indicates that the cause of the subsidence at Corpus Christi is the withdrawal of oil, gas, and associated groundwater.

Northward, in Refugio County (Figure A-13), subsidence rates averaged $8.3 \mathrm{~mm} / \mathrm{yr}$ between 1918 and 1943 and dropped to $2.9 \mathrm{~mm} / \mathrm{yr}$ between 1943-1951. Although groundwater withdrawals probably had great influence, the production of oil and gas may have contributed to subsidence, as the Refugio Old and Refugio New Oil and Gas Fields were discovered in 1920 and 1931.

\section{Subregion 3}

Because water level declines were not great enough to cause the subsidence measured in southeastern Victoria County, subsidence shown in this area (Figure $\mathrm{A}-14$ ) is probably related to oil and gas production. The highest rates 
calculated for Victoria County were $6.4 \mathrm{~mm} / \mathrm{yr}$ during 1918-1973 in association with the Placedo Oil Field and $19 \mathrm{~mm} / \mathrm{yr}$ during 1943-1951 for a small area not corresponding directly to an oil field.

\title{
Subregion 4
}

Local subsidence probably occurs in most of the oil and gas fields in the Bay City and Houston areas (Figure A-15), but the control needed to differentiate subsidence caused by oil and gas development from that caused by groundwater withdrawal is difficult to obtain.

One area where the causes have been differentiated is the Chocolate Bayou south of Houston (Grimsrud and others, 1978; Earth Sciences Associates, 1979). Grimsrud and others (1978, p. V-74) concluded that

\begin{abstract}
.... it appears that groundwater extraction alone is insufficient to account for all of the observed subsidence at Chocolate Bayou, nor can it account for the continuing increase in observed subsidence rate since 1950. Oil and gas with associated brine production from the Chocolate Bayou field is believed to have caused at least 0.5 to 1.2 feet 0.15 to 0.37 meters of the observed 1.8 feet 0.55 meters of maximum subsidence. Of the fluids withdrawn, it appears most likely that oil and brine extraction has been the principal cause of this subsidence.
\end{abstract}

The subsidence rate between 1943 and 1964 averaged $17 \mathrm{~mm} / \mathrm{yr}$ and between 1964 and 1973 averaged $20 \mathrm{~mm} / \mathrm{yr}$. More recent leveling data indicate that the subsidence rate decreased to $10 \mathrm{~mm} / \mathrm{yr}$ during 1973-1979 (Earth Sciences Associates, 1979). Lowered rates of subsidence since 1973 may reflect greatly reduced hydrocarbon production since the 1960's or decreased groundwater pumping rates (Earth Sciences Associates, 1979, p. A-3). Benchmarks northeast of Chocolate Bayou (towards Houston) did not show decreasing rates in 1979.

\section{$\underline{\text { Subregion } 5}$}

Subsidence of around $3 \mathrm{~mm} / \mathrm{yr}$ occurred west of Beaumont in Jefferson County (Figure A-16) during the period 1918-1977. This subsidence was probably caused by oil and gas production, because there are no water well fields in the area. 
Some of the highest subsidence rates in the Texas-Louisiana Gulf Coast have occurred in Jefferson County in the Spindletop Dome and Port Acres areas and are caused in part by oil and gas production and in part by solution mining of sulfur. At the Spindletop Dome, subsidence rates up to $29 \mathrm{~mm} / \mathrm{yr}$ between 1925 and 1977 have occurred in response to production of oil and gas. In addition, mining of sulfur has caused more subsidence in the same area, such that the maximum combined subsidence rate for $1970-1977$ was $205 \mathrm{~mm} / \mathrm{yr}$.

At the Port Acres site, also in Jefferson County, the subsidence rate was only $4.2 \mathrm{~mm} / \mathrm{yr}$ between 1954 and 1959 , but from 1959-1973 the rate increased to $63 \mathrm{~mm} / \mathrm{yr}$. During 1973-1977, small but additional subsidence occurred. Groundwater withdrawal in this area was insufficient to cause this much subsidence but the discovery and development of the Port Acres Gas Field in 1957 corresponds closely to the rapid increase in subsidence between 1959 and 1973.

\section{Louisiana}

Little has been reported on subsidence caused by oil and gas production in Louisiana (Figure A-17). This may be because very little subsidence caused by oil and gas production actually occurs in Louisiana, perhaps owing to the regulated spacing of wells (A. N. Turcan, personal commun., 1981). However, it also may be because not enough monitoring of subsidence in oil and gas fields has been done to document petroleum development-related subsidence (C. G. Grọat, personal commun., 1982), or that subsidence is just not reported. One of the three references found about petroleum development-related subsidence in Louisiana was given by the Louisiana Power and Light Company (1972, p. Q 2.45 A-2). They reported that a maximum of 6 centimeters of subsidence might possibly be attributed to oil extraction between depths of 1800 and 3700 meters in production areas along the Mississippi River between Baton Rouge and New Orleans during the period 1938-1964, a subsidence rate of $2 \mathrm{~mm} / \mathrm{yr}$. Gabrysch (personal commun., 1981) and Turcan (personal commun., 1981) both indicate that oil and gas production may also contribute to subsidence east of Lake Charles. 


\section{Solution Mining}

Very local but dramatic subsidence sometimes occurs when salt and sulfur are solution mined in coastal Texas and Louisiana. In Texas, Ratzlaff (1980) reports two areas that have subsided because of sulfur mining: Spindletop Dome in northern Jefferson County (Figure A-16) and the Moss Bluff Salt Dome area east of Houston (Figure A-15). The amount of subsidence attributable to sulfur mining at Spindletop Dome was estimated to exceed 3.0 meters between 1960 and 1977 (Ratzlaff, 1980, p. 6). Therefore, a very high subsidence rate of $176 \mathrm{~mm} / \mathrm{yr}$ is obtained for the Spindletop area. Added to the subsidence rate caused by oil production, a total of $205 \mathrm{~mm}$ of subsidence occurred annually between 1960 and 1977. In the Moss Bluff Salt Dome area, more than $4.6 \mathrm{~m}$ of subsidence caused by sulfur production was reported (Ratzlaff, 1980, p. 10). The time period over which the subsidence occurred was not reported, however, so a subsidence rate attributable to sulfur mining at the Moss Bluff Salt Dome is not shown in Figure A-15.

\section{Peat Deflation}

Deposits of peat are found throughout coastal Louisiana (Figure A-18). Environments in which peat forms include small restricted coastal basins between active distributary channels and broader inland flood basins separated by major Mississippi River courses. Coastal marsh belts between beach ridges of the chenier plain contain a relatively thin surface mantle of peat. (See Frazier and Osanik, 1969; Fisk, 1960; and Coleman, 1966.)

The swamps and marshes along the Mississippi River in the vicinity of New Orleans are underlain by peat deposits locally up to 5 meters thick (Fisk, 1960, p. 195; Snowden and others, 1979) (Figure A-19). Urban development and expansion beyond the relatively narrow natural Mississippi River levees has necessitated drainage of the marshes. Drainage canals and pumps were being used to drain the land by the 1920's, and levees were built to protect this newly drained land. (See Snowden and others, 1979.) Drainage of the marsh and peat deposits caused the water table to drop as much as three meters. Subsidence of the peat was initiated as the peat was exposed to the air, then oxidized and lost volume.

Land fill was added to compensate for the initial subsidence. Altogether, the 


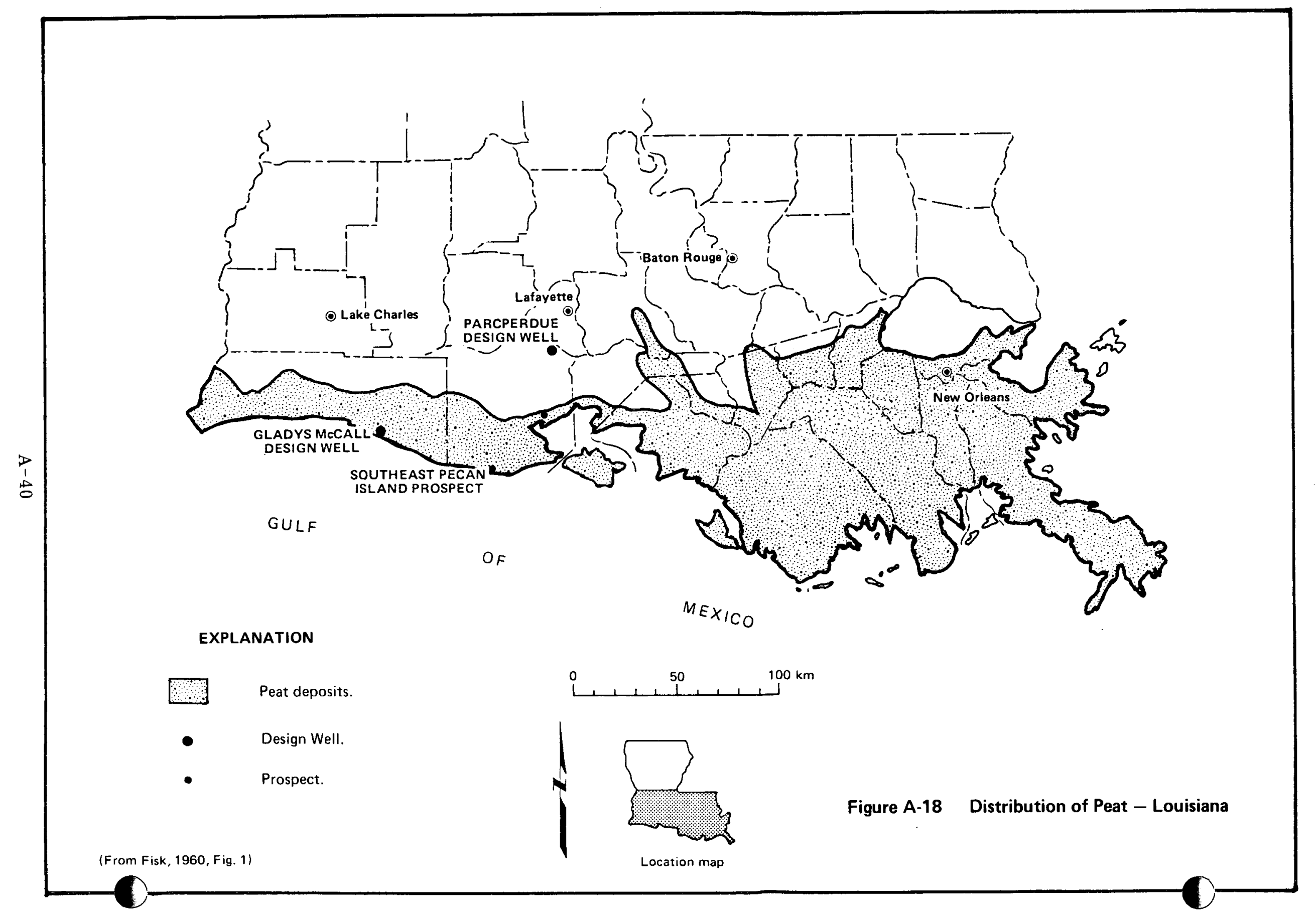




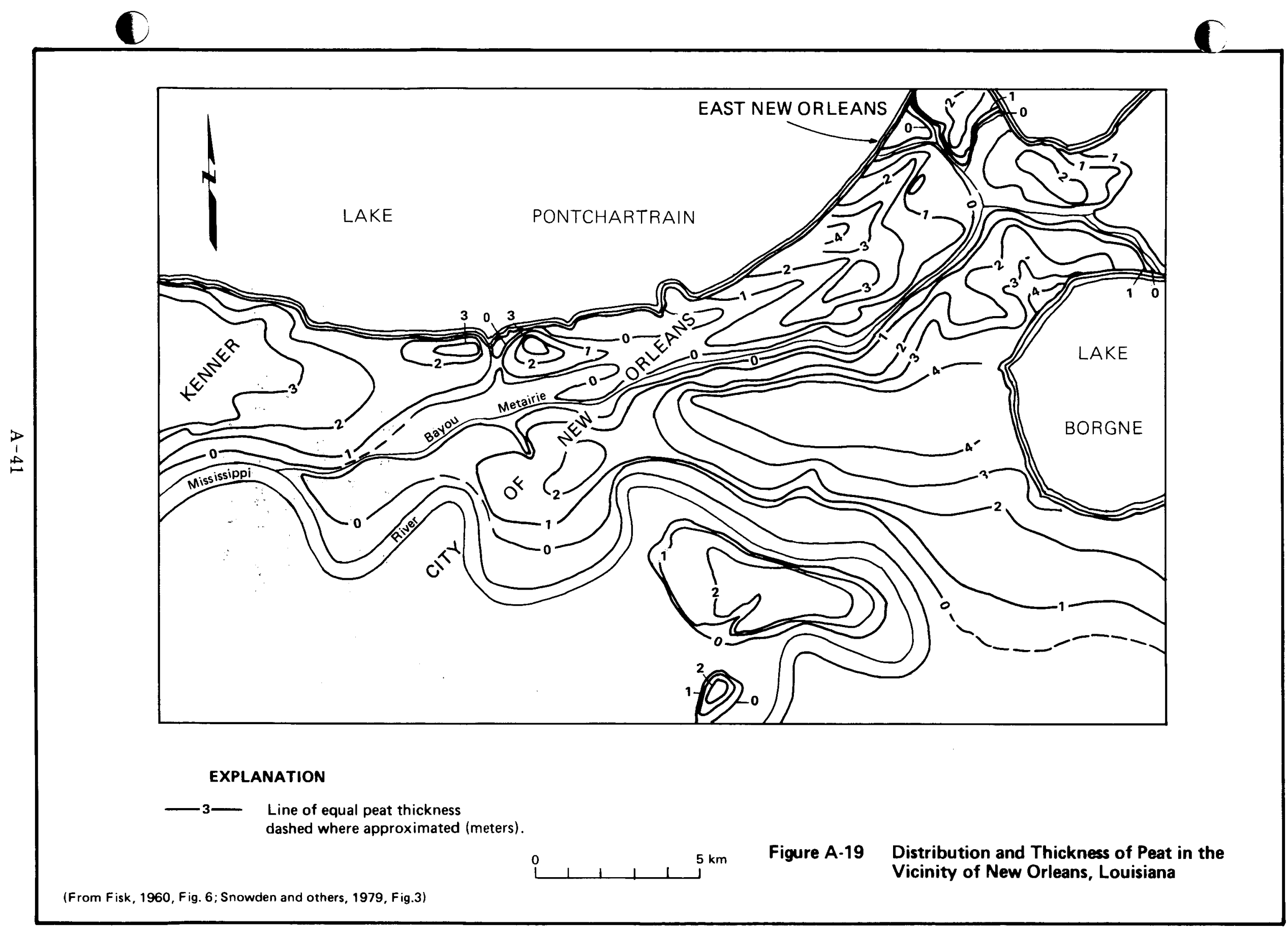


drainage and land filling processes have caused three types of peat deflation in the New Orleans area (Snowden and others, 1979):

1. Primary consolidation of the drained peat and underlying clays caused by lowering of the water table. As the load is transferred from the soil water to the soil solids, water is squeezed out of the void spaces.

2. Secondary consolidation of the peat and underlying clay from the loading of drained peat and land fill.

3. Oxidation of organic matter resulting in reduction of volume of the peat as chemical reactions occur which cause the organic matter to decompose.

In addition, with the building of the man-made levees, sediment was not allowed to flow into the marsh as it had previously, to help compensate for natural subsidence of the region.

West of New Orleans at Kenner in Jefferson Parish, subsidence caused by peat deflation has been studied by Snowden and Simmons (1979) and Snowden and others (1979). They report that subsidence occurred in such a way that an interior basin was formed between Lake Ponchartrain and the Mississippi River. Correspondingly, subsidence rates have been greater in the center of the basin than in the high "bands" of ground near the lake and river. The subsidence history of the Kenner area can best be described by time periods as shown in Figure A-20. This figure depicts the subsidence history for the northern half of the interior basin. Subsidence in the southern half was about $25 \%$ greater. Since the mid-1960's the subsidence rate has slowed and is now approximately between 13 and $25 \mathrm{~mm} / \mathrm{yr}$. If no further changes occur in the water table or drainage, the subsidence rate should continue to decrease, as shown by the dashed line extending beyond 1978 in Figure A-20. However, if the water table is lowered in the future, an increase in subsidence will occur, the rate of subsidence depending upon the rate of water table lowering.

The amount of subsidence in the New Orleans area correlates closely with measured peat thickness, amounts of water table lowering, and elapsed time since 


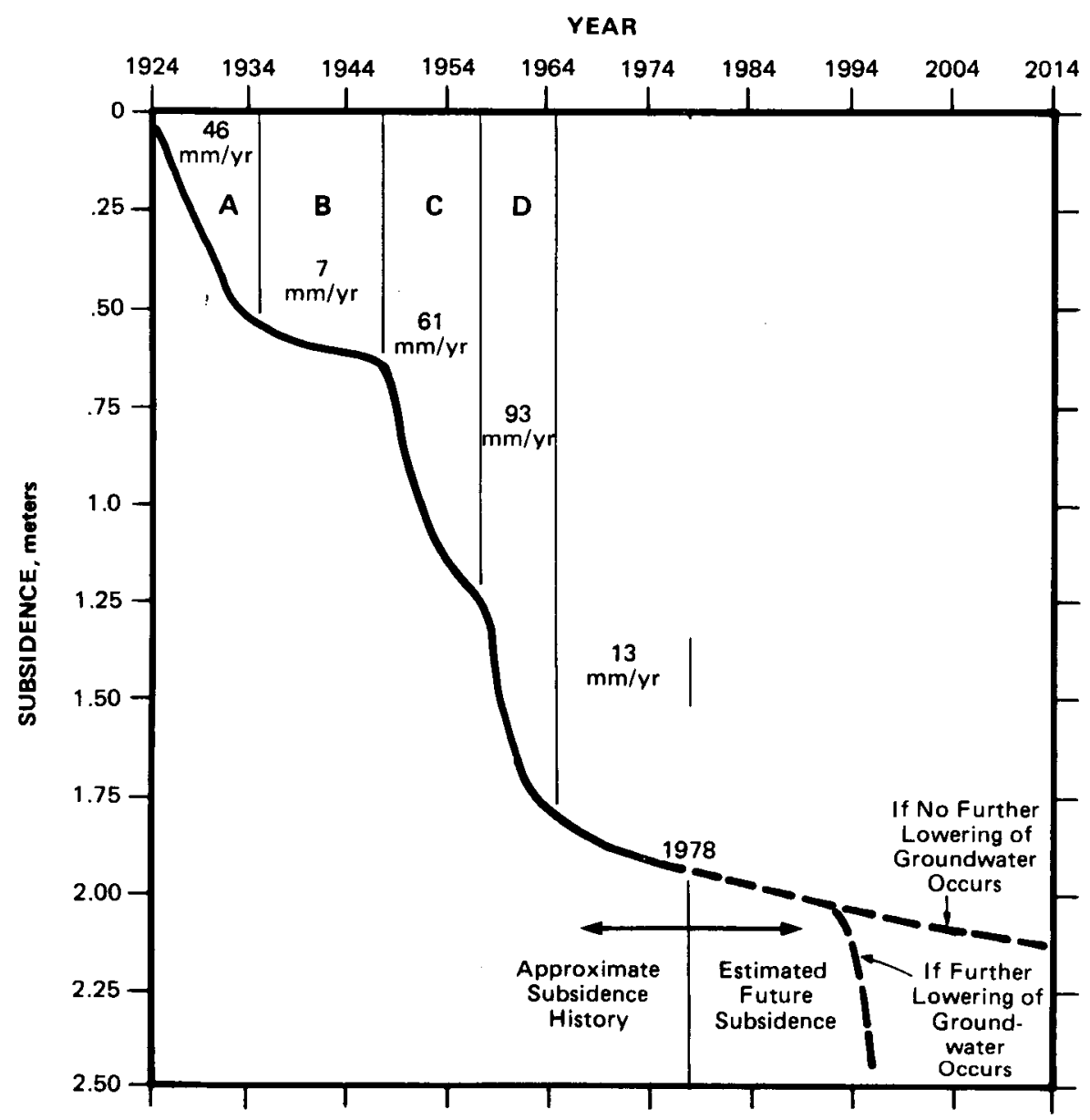
A Initial Pumping.
C Improved Surface Drainage and Levee Protection.
B Minimal Uniform Pumping.
D Increased Development and Subsurface Drainage.

Figure A-20 Approximate Subsidence History and Estimated Future Subsidence for Area in Kenner, Louisiana, Northern Part of Local Subsidence Basin 
land reclamation. Thus, Snowden and others (1979) believe it is possible to predict areas of existing and future development that will experience subsidence. Gagliano and others $(1972$, p. 10) anticipated that, within a few years after drainage, most of the New Orleans East area will have subsided 1.0 to 1.5 meters.

Elsewhere in Louisiana, peat deflation does not seem to be a major problem. This is because urbanization has not necessitated peat drainage which causes consolidation and oxidation. The Louisiana Geological Survey is now studying peat deposits throughout the state (L. Gorman, Louisiana Geological Survey, personal commun., 1981). The contribution of peat deflation to total background subsidence can better be analyzed when their study is completed.

\section{E. Local Consolidation}

Consolidation caused by the weight of minor landforms or structures, such as man-made levees, buildings, and drill rigs, contributes to subsidence locally. Where this occurs, the Holocene sediments in that area are depressed considerably more than the deposits over a more regional area. Subsidence of this type occurs in New Orleans, where the weight of buildings consolidates levees. Although important site-specifically, local consolidation has not been further analyzed in this study because of the difficulties in showing the effects of this local process on a regional scale.

\section{F. Hydrofracturing}

Turcan (personal commun., 1981) indicates that hydrofracturing (the pumping of water under high pressure into petroleum reservoirs to fracture the reservoir rock and increase the flow of oil to wells) may cause some uplift in Louisiana. Groat (personal commun., 1982) reports that any such uplift would be very small and less significant than diapiric uplift. Because specific cases have not been documented and the process is local in nature, uplift caused by hydrofracturing has not been mapped. 


\section{TOTAL BACKGROUND SUBSIDENCE RATES}

Several broad statements concerning background subsidence in the TexasLouisiana Gulf Coast can be made:

1. Subsidence decreases with distance inland. This correlates to a thinning of the Gulf Coast geosyncline inland.

2. A high proportion of the background subsidence in Louisiana is caused by natural processes.

3. In Texas, where the effect of natural processes is not so pronounced, the influence of man-induced processes dominates.

The highest subsidence rates for a significantly sized area occur in the Houston vicinity. These high rates $\left(70^{+} \mathrm{mm} / \mathrm{yr}\right)$ are caused mainly by groundwater withdrawal. The next highest rates $\left(40^{+} \mathrm{mm} / \mathrm{yr}\right)$ are caused by a totally different process - consolidation of Holocene sediments - within the modern Mississippi delta.

Composite maps of background subsidence rates in Louisiana and Texas are shown in Figures 21 and 22. They are based on the subsidence rate maps presented previously in this Appendix and on Holdahl and Morrison's 1974 map of elevation change in the southeast United States. No regional elevation survey more recent than Holdahl and Morrison's has been completed (Holdahl, personal commun., 1982). However, the Louisiana Geological Survey is now working on a releveling line from Sabine Lake to New Orleans. This survey line will be integrated with local surveys completed for Design Wells located in Louisiana.

A comparison of the total measured subsidence rates as shown on Holdahl and Morrison's map with total subsidence rates as compiled from maps presented in this Appendix shows that, while the general trends are consistent, there are minor differences that are hard to explain. These differences may come from data 


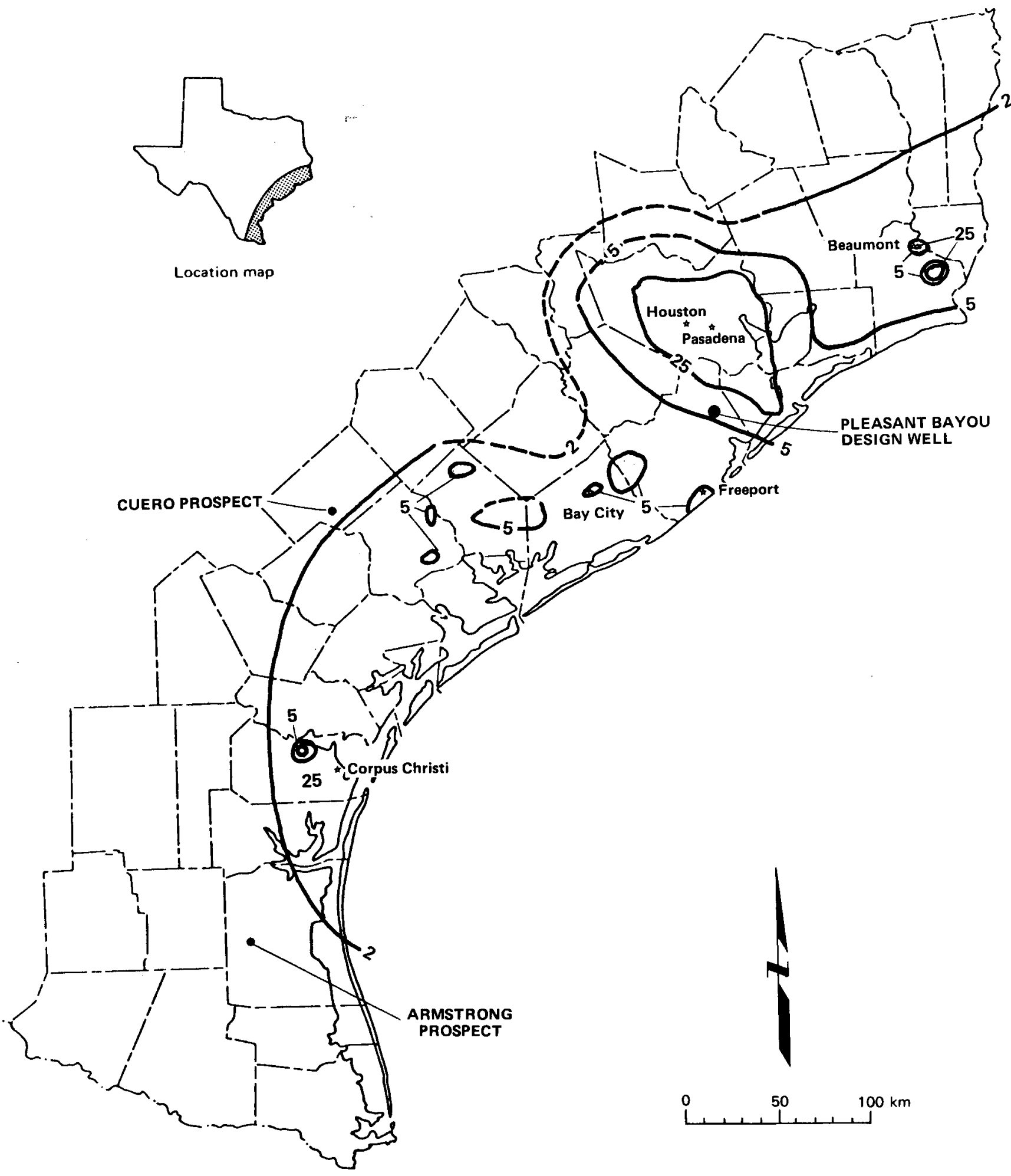

EXPLANATION

- Line of equal rate of subsidence $(\mathrm{mm} / \mathrm{yr})_{i}$ dashed where approximated.

- Design Well.

Figure A-21 Background Rates of Subsidence -

- Prospect. Texas 


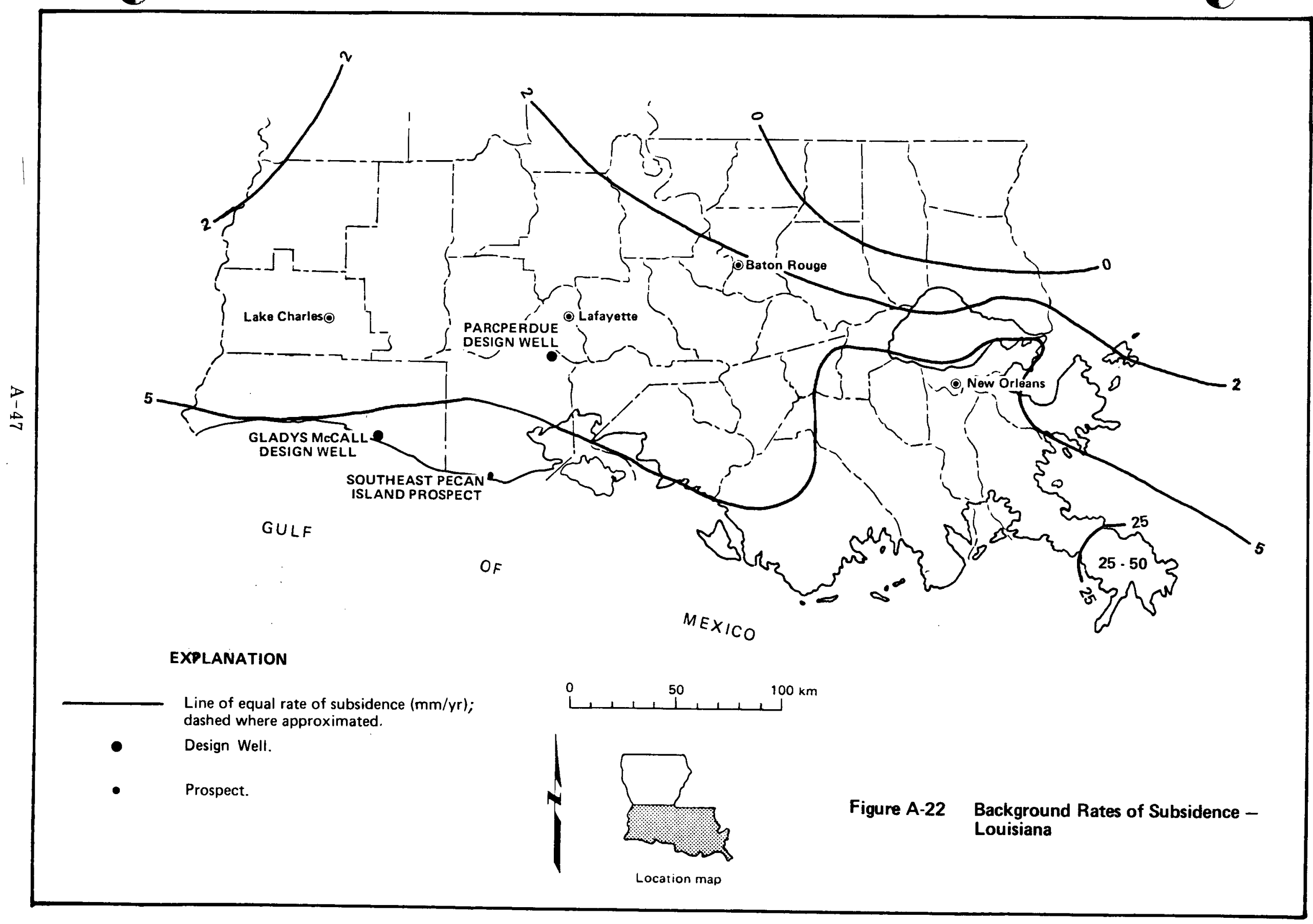


reduction errors (Holdahl, personal commun., 1982) or from a still imperfect knowledge of the contribution of each natural and man-induced process to total subsidence. Nevertheless, Figures A-21 and A-22 show the best possible determination of background subsidence rates in the Texas-Louisiana Gulf Coast based on data now available. 


\section{REFERENCES CITED}

Baker, E. T., Jr., 1978, Stratigraphic and hydrogeologic framework of part of the coastal plain of Texas: U.S. Geol. Survey Open-File Report 77-712, Texas Water Development Board, 32 p.

Bebout, D. G., and Gutierrez, D. R., 1981, Geopressured geothermal resource in Texas and Louisiana-Geological Constraints: Proceedings, Fifth Conference, Geopressured-Geothermal Energy, U.S. Gulf Coast, Baton Rouge, p. 13-24.

Bebout, D. G., Luttrell, P. E., and Seo, J. H., 1976, Regional Tertiary cross sections-Texas Gulf Coast: Geological Circular 76-5, The University of Texas at Austin, Bureau of Economic Geology.

Coleman, J. M., 1966, Recent coastal sedimentation: Central Louisiana coast: Coastal Studies Series, Baton Rouge, Louisiana State University, no. 17, 73 p.

Coleman, J. M., and Smith, W. G., 1964, Late recent rise of sea level: Bull. Geol. Soc. Am., v. 75, p. 833-840.

Curray, J. R., 1960, Sediments and history of Holocene transgression, continental shelf, northwest Gulf of Mexico, p. 221-266, in Shepard, F. P., and others, (eds.), Recent sediments, northwest Gulf of Mexico - a symposium: Am. Assoc. Petroleum Geologists Bulletin, $394 \mathrm{p}$.

Davis, G. H., and Rollo, J. R., 1969, Land subsidence related to decline of artesian head at Baton Rouge, lower Mississippi Valley, U.S.A.: Association Internationale d'Hydrologie Scientifique, Actes du Colloque de Tokyo, p. 174184, in Whiteman, C. D., Jr., 1980, Measuring local subsidence with extensometers in the Baton Rouge Area, Louisiana 1975-1979: Water Resources Technical Report, Baton Rouge, Louisiana Department of Transportation and Development, Office of Public Works, in cooperation with the U.S. Geol. Survey, no. 20, 18 p.

Earth Sciences Associates (ESA), 1979, Cocolate Bayou-data assessment study: Palo Alto, California, job no. 2048.

Fisk, H. N., 1960, Recent Mississippi River sedimentation and peat accumulation: Quatrieme Congrès pour L'avancement des Etudes de Stratigraphie et de Géologie du Carbonifere, September 15-20, 1958, Heerlen, Compte Rendu, Maastricht, Netherlands, p. 189-199.

Fisk, H. N., and McFarlan, E., Jr., 1955, Late Quaternary deltaic deposits of the Mississippi River, in Poldevaart, A., ed., Crust of the Earth-a symposium: Geol. Soc. America, Special Paper 62, p. 279-301.

Frazier, D. E., 1967, Recent deltaic deposits of the Mississippi River; their development and chronology: Trans. Gulf Coast Assoc. Geol. Soc., v. 17, p. 287-315. 
Frazier, D. E., and Osanik, A., 1969, Recent peat deposits-Louisiana coastal plain, in Dapples, E. C., and Hopkins, M. C., eds., Environments of Coal Deposition: Geol. Soc. Amer. Special Paper 114, p. 63-85.

Gabrysch, R. K., 1969, Land-surface subsidence in the Houston-Galveston region, Texas, in Land Subsidence, Proc., Tokyo Symposium, IASH/AIHS-UNESCO, p. $43-54$.

Gabrysch, R. K., 1972, Development of groundwater in the Houston district, Texas, 1966-1969: Texas Water Development Board Report 152, 24 p.

Gabrysch, R. K., 1977, Land surface subsidence in the Houston-Galveston region, Texas: Proc. 2nd International Symposium on Land Subsidence, Anaheim, California, December 1976, p. 16-24.

Gabrysch, R. K., 1980, Approximate land-surface subsidence in the HoustonGalveston region, Texas 1906-78, 1943-78, and 1973-78: U.S. Geol. Survey Open-File Report 80-338.

Gabrysch, R. K., and Bonnet, C. W., 1975, Land-surface subsidence in the HoustonGalveston Region, Texas Water Development Board 188, 19 p.

Gagliano, S. M., Earle, D. W., Jr., Rowland, A. C., and Templet, P. J., 1972, Environmental evaluation of the New Orleans East area: Baton Rouge, Louisiana, Louisiana State University, Center for Wetland Resources, Coastal Resources Unit, 135 p.

Grimsrud, G. P., Turner, B. L., and Frame, P. A., 1978, Areas of ground subsidence due to geofluid withdrawal: Geothermal Subsidence Research Management Program, Berkeley, California, Lawrence Berkeley Laboratory, Earth Sciences Division, GSRMP-4, LBL-8618.

Gustavson, T. C., 1979, Environmental baseline monitoring in the area of General Crude Oil-Department of Energy Pleasant Bayou Number 1-A geopressuredgeothermal test well-1978, Introduction and technical report, Annual report: The University of Texas at Austin, Bureau of Economic Geology, v. 1, 33 p.

Hicks, S. D., 1972, On the classification and trends of long period sea-level series: Shore and Beach, v. 40, p. 20-23.

Holdahl, S. R., and Morrison, N. L., 1974, Regional investigations of vertical crustal movements in the U.S., using precise relevelings and mareograph data: Tectonophysics, v. 23, p. 373-390.

Jones, P. H., and Wallace, R. H., Jr., 1974, Hydrogeologic aspects of structural deformation in the northern Gulf of Mexico basin: Jour. Research U.S. Geol. Survey, v. 2, no. 5, p. 511-517.

Kazmann, R. G., 1970, The present and future groundwater supply of the Baton Rouge area: Baton Rouge, Louisiana State University Bull. 5, Louisiana Water Resources Research Institute. 
Kazmann, R. G., and Heath, M. M., 1968, Land subsidence related to groundwater offtake in the New Orleans area: Trans. Gulf Coast Assoc. Geol. Soc., v. 18, p. 108-113.

Kolb, C. R., and Van Lopik, J. R., 1958, Geology of the Mississippi River deltaic plain, southeastern Louisiana: U.S. Waterways Experiment Station, Technical Report No. 3-484, v. 1, 120 p.

Louisiana Geological Survey, 1981, Regional cross sections of western Louisiana Gulf Coast: unpublished, 9 cross sections.

Louisiana Power and Light Company, 1972, Dockets concerning the Waterford steam electric station: on file at Earth Sciences Associates, Palo Alto, California.

Martinez, J. O., Kupfer, D. H., Thoms, R. L., Smith, C. G., and Kolb, C. R., 1975, An investigation of the utility of Gulf Coast salt domes for the storage or disposal of radioactive wastes: Baton Rouge, Louisiana State University, Institute of Environmental Studies, 204 p.

Mauk, F. J., Sorrels, G. G., and Kimball, B. C., 1981, Microseismicity associated with development of Gulf Coast geopressured-geothermal energy wells: Proceedings, Fifth Conference, Geopressured-Geothermal Energy, U.S. Gulf Coast, Baton Rouge, p. 105-108.

McGookey, D. P., 1975, Gulf Coast Cenozoic sediments and structure: an excellent example of extra-continental sedimentation: Trans. Gulf Coast Assoc. Geol. Soc., v. 25, p. 104-120.

Morgan, J. P., 1967, Ephemeral estuaries of the deltaic environment, in Lauff, G. H., ed., Estuaries: Washington, D.C., American Association for the Advancement of Science, Publication no. 83, p. 115-120.

Morgan, J. P., 1972, Impact of subsidence and erosion on Louisiana coastal marshes and estuaries: Coastal Marsh \& Estuary Management Symposium, Baton Rouge, Louisiana State University, p. 217-233.

Ratzlaff, K. W., 1980, Land-surface subsidence in the Texas coastal region: U.S. Geol. Survey Open-File Report 80-969, Austin, Texas Department of Water Resources, 19 p.

Russell, R. J., 1936, Physiography of Lower Mississippi River delta: Geol. Bull., State of Louisiana, Dept. Conserv., no. 8, p. 3-199.

Saucier, R. T., 1963, Recent geomorphic history of the Pontchartrain Basin: Coastal Studies Series, Louisiana State University Studies, no. 9, 114 p.

Shepard, F. P., 1960, Rise of sea level along northwest Gulf of Mexico, in Shepard, F. D., Phleger, F. B., and van Andel, T. H., eds., Recent sediments, northwest Gulf of Mexico - a symposium: Am. Assoc. Pet. Geol., p. 338-344.

Shlemon, R. J., 1975, Subaqueous delta formation - Atchafalaya Bay, Louisiana: in Broussard, M. L., ed., Deltas, models for exploration: Houston Geol. Soc., p. 209-221. 
Smith, C. G., Jr., and Kazmann, R. G., 1978, Subsidence in the capital area groundwater conservation district: Bulletin, Capital Area Groundwater Conservation Commission, Baton Rouge, Louisiana, no. 2.

Snowden, J. O., and Simmons, W. B., 1979, Differential subsidence on reclaimed marshland peat in metropolitan New Orleans, Louisians, in Saxena, S. K., ed., Evaluation and prediction of subsidence: International Conference on Evaluation and Prediction of Subsidence, Pensacola Beach, Florida, January, 1978, American Society of Civil Engineers, p. 479-499.

Snowden, J. O., Simmons, W. B., and Traughber, E. B., 1979, Subsidence of marshland peat in the greater New Orleans area, Louisiana, in Day, J. W., Culley, D. D., Turner, R. E., and Mumphrey, A. J., Jr., eds., Proc. Third Coastal Marsh and Estuary Management Symposium, Louisiana State University, Baton Rouge, p. 273-289.

Swanson, R. L., and Thurlow, C. I., 1973, Recent subsidence rates along the Texas and Louisiana coasts as determined from tide measurements: $J$. of Geophysical Research, v. 78, no. 15, p. 2665-2671.

Trowbridge, A. C., ed., 1962, Dictionary of Geological Terms: prepared under the direction of the American Geological Institute, Garden City, New York, Dolphin Books, Doubleday \& Co. Inc., 545 p.

U.S. Geol. Survey, 1966, Explanation of effect of subsidence on USGS levels in southern Louisiana: one-page information sheet, Rolla, Missouri.

Van Sickle, V. R., and Groat, C. G., 1981, Subsidence and induced faulting: Key environmental issues in geopressured-geothermal resource development: Proceedings, Fifth Conference, Geopressured-Geothermal Energy, U.S. Gulf Coast, Baton Rouge, p. 325-330.

Walper, J. L., Henk, F. H., Jr., Loudon, E. J., and Raschilla, S. N., 1979, Sedimentation on a trailing plate margin: the northern Gulf of Mexico: Trans. Gulf Coast Assoc. Geol. Soc., v. 29, p. 188-201.

Whiteman, C. D., Jr., 1980, Measuring local subsidence with extensometers in the Baton Rouge area, Louisiana, 1975-1979: Water Resources Technical Report, Baton Rouge, Louisiana Department of Transportation and Development, Office of Public Works, in cooperation with the U.S. Geol. Survey, no. 20, $18 \mathrm{p}$.

Wintz, W. A., Jr., Kazmann, R. G., and Smith, C. G., Jr., 1970, Subsidence and groundwater offtake in the Baton Rouge areas: Bulletin, Baton Rouge, Louisiana, Louisiana State University, Louisiana Water Resources Research Institute, no. 6. 


\section{DO NOT MICROFLM COVER

This report was done with support from the Department of Energy. Any conclusions or opinions expressed in this report represent solely those of the author(s) and not necessarily those of The Regents of the University of California, the Lawrence Berkeley Laboratory or the Department of Energy.

Reference to a company or product name does not imply approval or recommendation of the product by the University of California or the U.S. Department of Energy to the exclusion of others that may be suitable. 


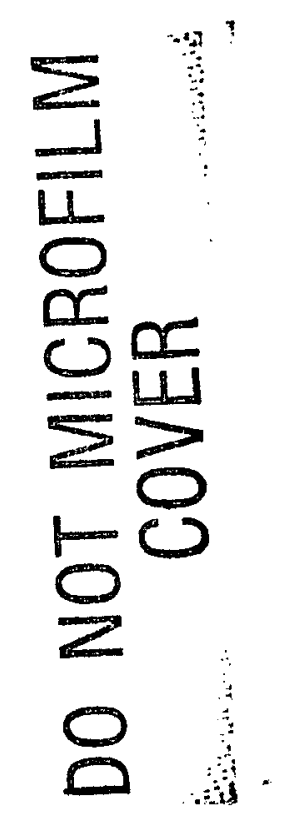

